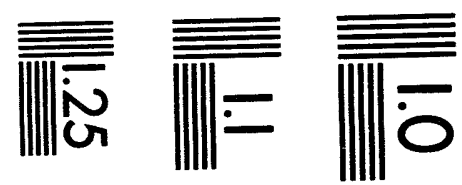

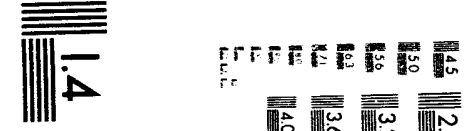

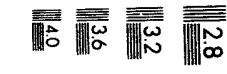

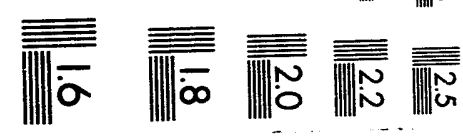



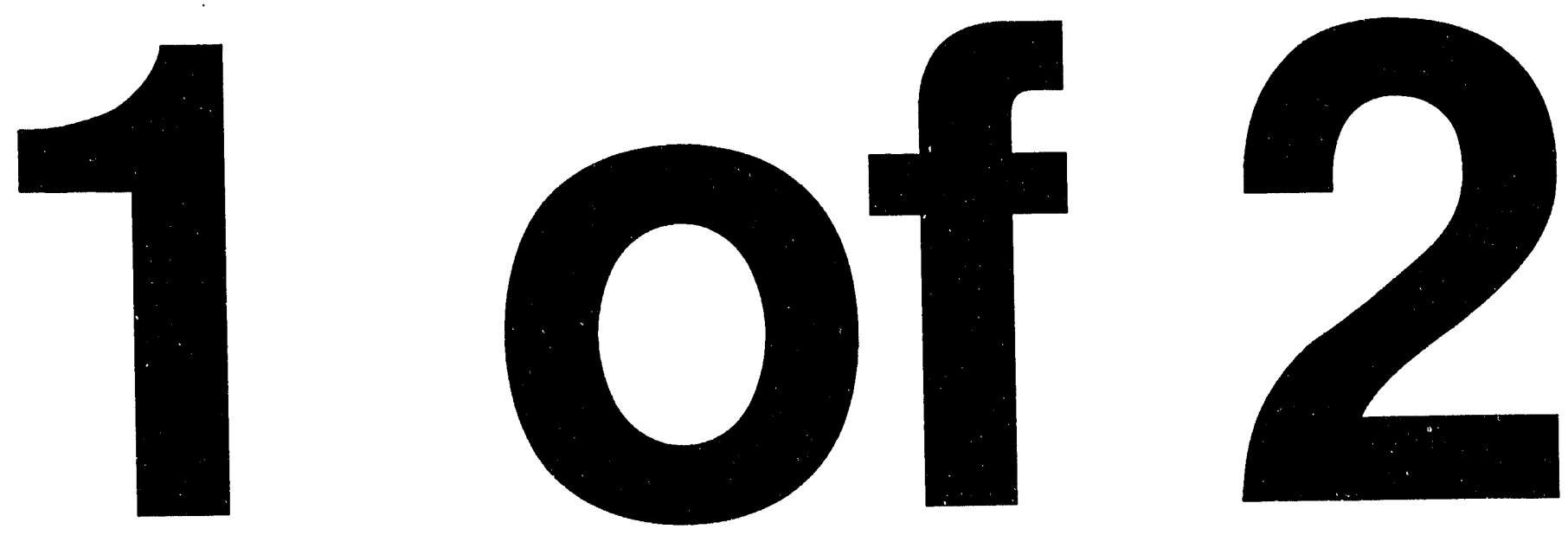
LBL-33587

UC-000

\title{
WORLDWIDE STATUS
}

\section{OF}

\section{ENERGY STANDARDS FOR BUILDINGS}

\author{
Appendices \\ (supporting material for the authors' article of the same title, \\ published in Energy-The International Journal, 19:1, 1994)
}

\author{
Kathryn B. Janda \\ and \\ John F. Busch
}

February 1993

Energy Analysis Program

Energy and Environment Division

Lawrence Berkeley Laboratory

University of California

Berkeley, CA 94720 USA

This work was funded by the U.S. Agency for International Development and by the Assistant Secretary for Conservation and Renewable Energy, Office of Building Technologies, of the U.S. Department of Energy under Contract No. DE-AC03-76SF00098. 


\section{Table of Contents}

Appendix A

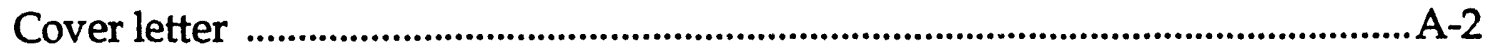

Survey ……................................................................................................................

Appendix B

Input Key .......................................................................................................... B-2

Short form of selected results (from all 59 respondents) ......................................... B-4 Appendix C

Surveyed Details of Selected Energy Standards in 35 Countries

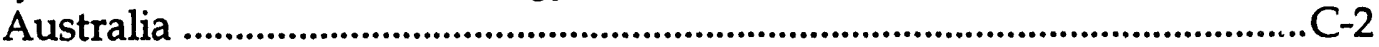

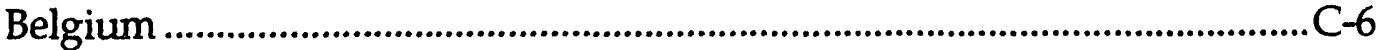

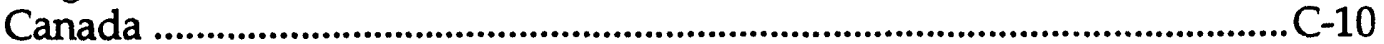

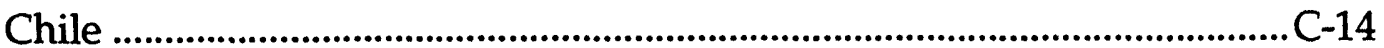

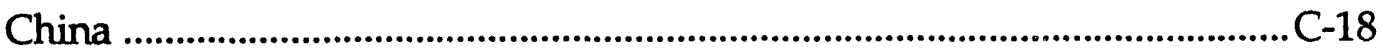

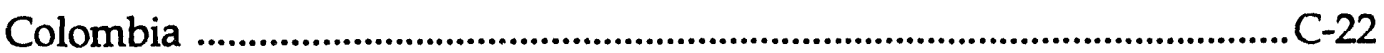

Czechoslovakia (former) ........................................................................ -26

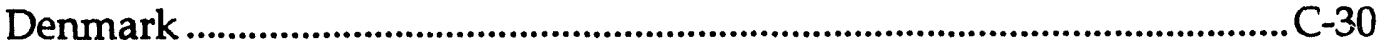

England \& Wales ........................................................................................... -34

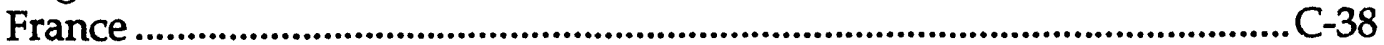

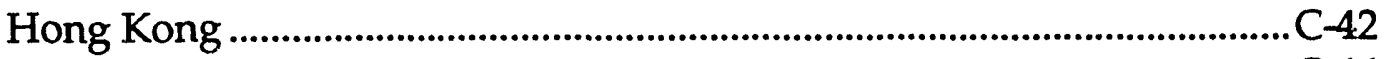

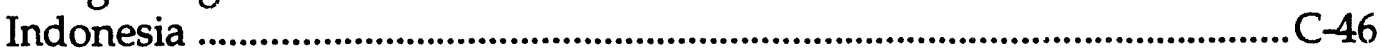

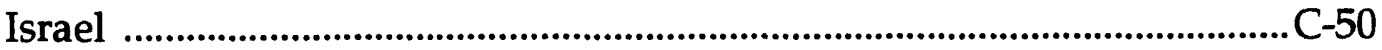

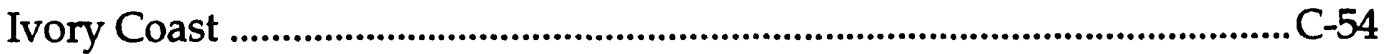

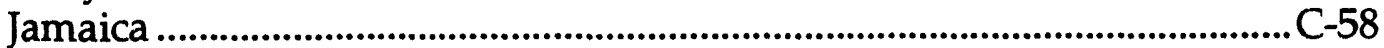

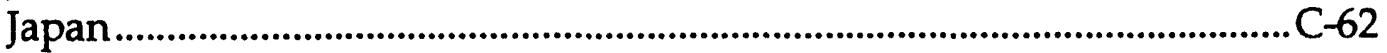

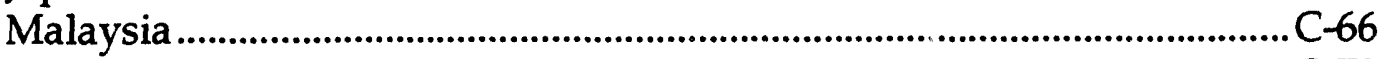

Netherlands ....................................................................................................... -

New Zealand ........................................................................................................

Northern Ireland …….................................................................................. C-78

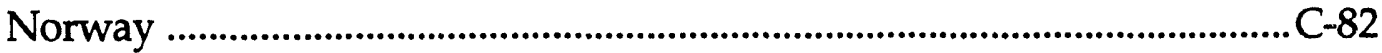

Pakistan ................................................................................................. -86

Philippines ...................................................................................................... C-90

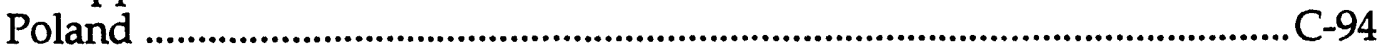

Portugal ..................................................................................................... C-98

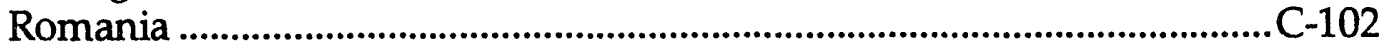

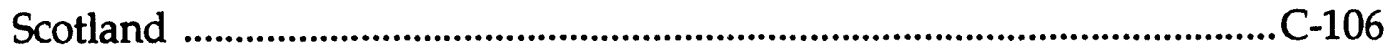

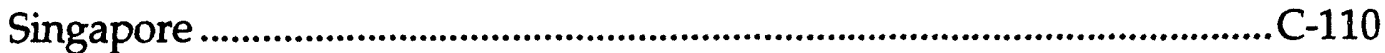

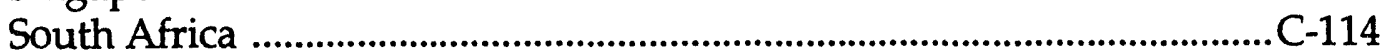

South Korea ...................................................................................118

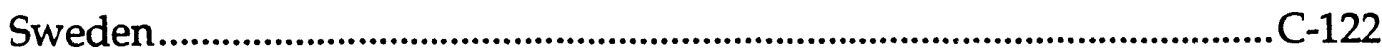

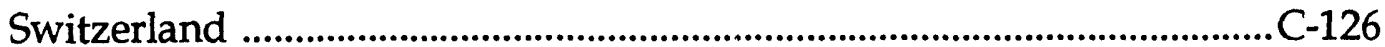

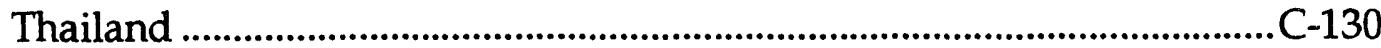

U.S.S.R. (former) ........................................................................................... -134

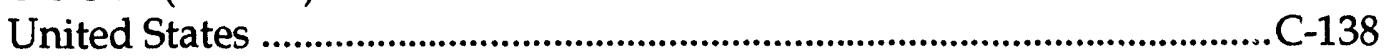




\section{APPENDIX A}

Cover Letter to Respondents

and

Mail Survey 
Dear Respondent:

This is an informal survey designed to gain information about the worldwide status of energy efficiency standards for buildings, particularly for non-residential buildings including offices, schools, and hotels. Our project has three goals: 1) to understand and learn from the experience of countries with existing building energy standards; 2 ) to locate areas where these lessons might be applied and energy standards might be effectively proposed and developed; and 3) to share the information gathered with all participating countries.

\begin{abstract}
About the term "standard"
We want to gain information about activities undertaken specifically for the purpose of INCREASING ENERGY EFFICIENCY in buildings and gather existing documentation on this subject. For the purposes of this survey, we will use the word "standard" to refer interchangeably to what also might be called codes, criteria, guidelines, norms, laws, protocols, provisions, recommendations, requirements, regulations, rules, or standards. Depending on the country, the "standard" may be contained in one document, be part of another larger document (such as a general building code), or be comprised of several documents.
\end{abstract}

We are sending this survey to contacts around the world who hold various positions in organizations ranging from government to academia to professional associations. Since we designed the survey to be answered by people with this breadth of background, it is likely that some of the questions on the following pages may lie outside your area of expertise. If you should find yourself uncertain about a particular question or set of questions, please answer the survey to the best of your knowledge, adding a question mark (?) or comment in the space provided. If you could suggest someone else who would know the answers to some of these questions about your country, please include their name(s) and contact information so we can solicit their input. If convenient, you may also photocopy this survey and give them a copy for their use.

Since overseas mail can often be time-consuming and uncertain, we would appreciate receiving your responses by telefax if possible.

Thank you for taking the time to participate in this survey. Please contact us if you have any questions that need immediate attention.

John Busch, Ph.D.

Kathryn Janda

Tel: +1 510-486-5793

Fax: +1 510-486-6996

e-mail: kbjanda@dante.lbl.gov 
Lawrence Berkeley Laboratory Building Energy Standards Survey, 1992

\section{STANDARDS FOR ENERGY EFFICIENCY IN BUILDINGS}

IN (please fill in the name of your country)

The focus of our research is on ENERGY STANDARDS for NON-RESIDENTIAL BUILDINGS. This survey has been designed to solicit information about this particular subject, and some questions may not apply equally to all types of energy standards for buildings. Please respond as appropriate for the situation in your country.

\section{SECTION I: GENERAL OVERVIEW OF BUILDING ENERGY STANDARDS}

1. Does your country have BUILDING STANDARDS of ANY KIND (e.g., health, structural safety, fire prevention)?
a. At the NATIONAL level?

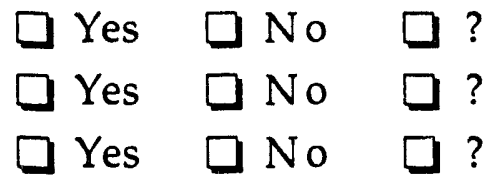
b. At the STATE or regional level?
c. At the LOCAL or municipal level?
d. $\square$ There are no building standards of ANY kind at any level. (Go to Question 20.)

2. Some countries have STANDARDS to INCREASE the ENERGY EFFICIENCY of BUILDINGS. Such standards can be voluntary or mandatory, and they are often developed, issued, and/or implemented by governments, electric utilities, industry groups, or professional associations.

To the best of your knowledge, are there any proposed or existing ENERGY EFFICIENCY STANDARDS for BUILDINGS in your country? (Check EITHER $a$ or b.)

a. Energy standards for buildings DO NOT EXIST at the national, regional or local level. (Go to Question 20.)

b. $\square$ Energy standards for buildings DO EXIST (or have been proposed) at the national, regional, or local level.

Which building sectors are covered by these standards?

(Check ONE of the following.)

1. $\square$ Residential buildings ONLY (Go to Question 4)

2. $\square$ Non-residential buildings ONLY (e.g., commercial, institutional)

3. BOTH non-residential and residential buildings

4. $\square$ Other: (Please specify.) 
3. a. What is the status of energy standards for NON-RESIDENTIAL buildings at the NATIONAL level in your country? (Check all that apply.)

Mandatory - compliance with standard legally required for construction approval

Voluntary - compliance with standard recommended but not necessary

Proposed - standard has been developed and is currently under consideration

None - no building energy standard has been developed or proposed

Uncertain - there may or may not be a standard at this level

Approximately how many voluntary or mandatory NATIONAL ENERGY STANDARDS apply to non-residential buildings in your country?

b. What is the status of energy standards for NON-RESIDENTIAL buildings at the STATE or REGIONAL level? (Check all that apply.)

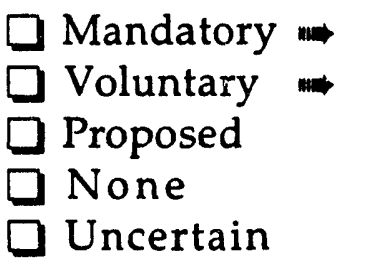

1. Approximately how many MANDATORY or VOLUNTARY regional energy standards apply to non-residential buildings in your country?

2. What states or regions have adopted them?

c. What is the status of energy standards for NON-RESIDENTIAL buildings in LOCAL AREAS or CITIES in your country? (Check all that apply.)

$\square$ Mandatory
$\square$ Voluntary
$\square$ Proposed
$\square$ None
$\square$ Uncertain

1. Approximately how many MANDATORY or VOLUNTARY local energy standards apply to non-residential buildings in your country?

2. What cities or municipal areas have adopted them? 
4. Please use the following criteria to select a SINGLE energy standard (or set of standards) as a basis for answering Questions 5-19. (Check all that apply and identify standard below.)

1. This energy standard applies to the largest number of non-residential buildings.

2. I am most familiar with this energy standard.

3. There is ONLY ONE energy standard for NON-RESIDENTIAL buildings.

4. There are NO energy standards for NON-RESIDENTIAL buildings; this standard applies to buildings.

Energy Standard Title:

Date (Specify adopted, effective, or published):

Issuing Organization:

Geographic area covered:

\author{
$\square$ Nation \\ Region(s): (specify) \\ City(ies): (specify)
}

\title{
SECTION II: DESCRIPTION OF SPECIFIED ENERGY STANDARDS
}

5. To what kinds of buildings does the standard specified in Question 4 apply?

a. Please indicate BUILDING TYPE(s): (Check all that apply.)

$\begin{array}{lll}\square \text { Offices } & \square \text { Restaurants } & \square \text { Retail stores } \\ \square \text { Hotels } & \square \text { Hospitals } & \square \text { Schools } \\ \square \text { Government facilities } & \square \text { Churches/mosques } \square \text { Industrial Buildings } \\ \square \text { Residential (single-family) } & \square \text { Residential (multi-family) } \\ \square \text { ALL Buildings } & \square \text { Other: (Please specify.) }\end{array}$

b. Please indicate BUILDING VINTAGE: (Check one.)

$\square$ New buildings

Existing buildings (through retrofits)

$\square$ Both new and existing buildings 
c. Please indicate any ADDITIONAL BUILDING CHARACTERISTICS used to define the scope of the standard's applicability: (Check all that apply.)

1. $\square$ Physical size (e.g., floor area)

- What size limit(s)?

2. Amount of energy used (e.g., kilowatts)

What amount(s)?

3. Type of fuel used (e.g., electricity)

$m$ Which fuel(s)?

4. Air-conditioned

5. Other: (Please specify.)

6. Which of the following terms best describes the basic approach of the standard(s) specified in Question 4? (Check one.)

Prescriptive (i.e. building materials or dimensions of some building elements are specified)

$\square$ Performance-based

(i.e. design flexibility is maintained within a specified level of performance of the building element, system, or building as a whole)

Both prescriptive and performance methods are used in the standard.

$\square$ Other (Please describe):

7. Are the following subjects INCLUDED in the energy standard identified in Question 4 ?

a. Whole-building ENERGY REQUIREMENTS/limitations: $\square$ Yes $\square$ No $\square$ ? If yes, check all that apply below:

Energy target (e.g., total btu or kilowatt-hour/floor area)

Peak electricity demand (e.g., peak kilowatt-hours/floor area)

Energy cost target

Other (Please specify): 
b. BUILDING ENVELOPE heat loss or heat gain provisions: $\square$ Yes $\square$ No $\square$ ? If yes, check all that apply below:

Roof

Wall system (e.g., insulation, exterior surface color)

Fenestration system (e.g., glass type, amount, placement of windows)

Infiltration (e.g., air changes per hour)

Other (Please specify):

c. LIGHTING provisions (interior or exterior):

If yes, check all that apply below:

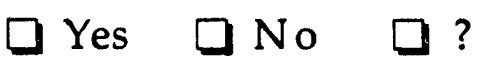

Control requirements or credits (e.g., occupancy sensors, number of switches, time clocks)

$\square$ Installed lighting power density requirements $\left(\mathrm{W} / \mathrm{m}^{2}\right)$

D Illumination requirements (lux, footcandles)

$\square$ Other (Please specify):

d. MECHANICAL provisions:

If yes, check all that apply below:

$\square$ Yes $\square$ No $\square$ ?

Air/water distribution efficiency

Load calculations for equipment sizing (e.g., chillers, motors)

Controls (e.g., energy management systems, time clocks)

$\square$ Ventilation

Equipment efficiency (e.g., motors, chillers, fans)

$\square$ Other (Please specify):

e. Are there any OTHER major provisions included in the standard(s) that have not been described above? (e.g., electrical specifications, thermostat settings, duration of heating or cooling season)

If yes, please specify:

$\square$ Yes $\square$ No $\square$ ?

\footnotetext{
fres, please specify:
} 


\section{SECTION III: STANDARDS DEVELOPMENT PROCESS}

8. Please list the names of the ORGANIZATIONS that played important roles in DEVELOPING the ENERGY standard specified in Question 4: (Attach additional pages if necessary.)

Types of Organizations:

$\mathrm{G}=$ Government agency

$I$ = Industry group (e.g., equipment or material suppliers)

$A=$ Academic institution

$\mathbf{R}=$ Research group (public or private)

$\mathbf{L}=$ Local interest group

$\mathbf{F}=$ Foreign development agency (or other non-local institution)

$\mathbf{O}=$ Other (please describe)
a. Organization Name:
Type: (See list above)
b. Organization Name:
Type: (See list above)
c. Organization Name:
Type: (See list above)
d. Organization Name:
Type: (See list above)

9. Which one of the following two terms BEST describes the PROCESS involved in deciding what requirements the standard should contain? (Check one and describe below.)

a. $\square$ Consensus - several different organizations reached a compromise (If different from those listed in Question 8, please name organizations involved and comment below)

b. $\square$ Mandate - a single organization or entity made most decisions (Please provide the name of this organization or entity below) 
10. Standards are generally developed using information about physical attributes and energy use of existing buildings and climate data for the geographic area. What kind of information was used in developing the energy standard specified in Question 4? (Check all that apply.)

a. PHYSICAL CHARACTERISTICS of existing buildings (e.g., size, function, types of walls and windows)

1. Not available, and not used in standard.

2. $\square$ Estimated using professional judgement.

3. $\square$ Gathered through audits or surveys for the purpose of the standard.

4. $\square$ Already available prior to standard development.

b. ENERGY USE of existing buildings (e.g., annual consumption, peak demand, load patterns)

1. $\square$ Not available, and not used in standard.

2. Estimated using professional judgement.

3. Estimated through computer simulations.

4. $\square$ Gathered through audits or surveys for the purpose of the standard.

5. Already available prior to standard development.

c. WEATHER data (e.g., direct and indirect solar radiation, temperature, humidity)

1. Not available, and not used in standard.

2. Estimated using professional judgement.

3. Gathered through measurements for the purpose of the standard.

4. Already available prior to standard development.

d. Other information: (Please specify)

11. Energy standards are often developed with reference to standards from other countries.

Were standards or information from a DIFFERENT COUNTRY (i.e., other than your own) used in developing the energy standard specified in Question 4?

No

Yes Please specify the country(ies) of origin and kind(s) of information used: (e.g. American: ASHRAE 90.1-1989; Jamaica: EEBC-90) 
12. In developing the standard, computer simulations are sometimes used to determine energy and economic performance of different building designs. Were any COMPUTER PROGRAMS (e.g., DOE-2 or other building energy models) used in the development of the standard?

$\square$ No (Go to Question 13.)

- Yes $m$ a. Which programs?

b. Are computer simulations also used to attain COMPLIANCE with the standard?

$\square$ Yes $\square$ No $\square$ Uncertain

- If yes and different from above, please list:

13. Which of the following statements best describes the goal of the standard, as depicted in the graphs below? (Check one.)

a. The standard is set at a level LOWER THAN CURRENT PRACTICE to eliminate the most inefficient building designs.

b. $\square$ The standard is set at a level approximately EQUAL TO CURRENT PRACTICE to encourage moderate levels of efficiency.

c. The standard is set at a level ABOVE CURRENT PRACTICE to promote highlyefficient buildings and encourage technological development.

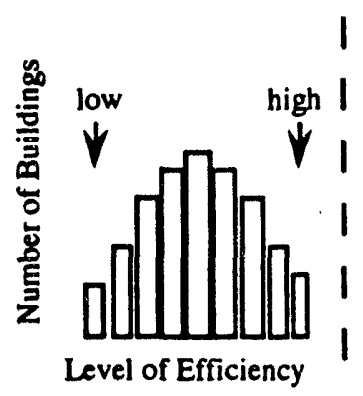

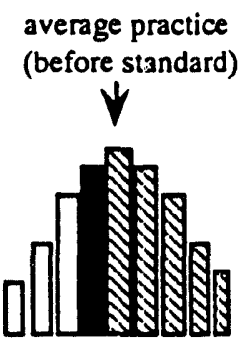

a.

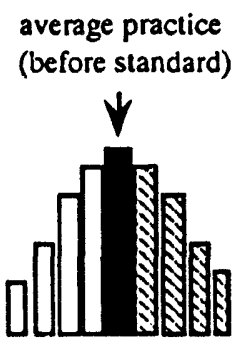

b.

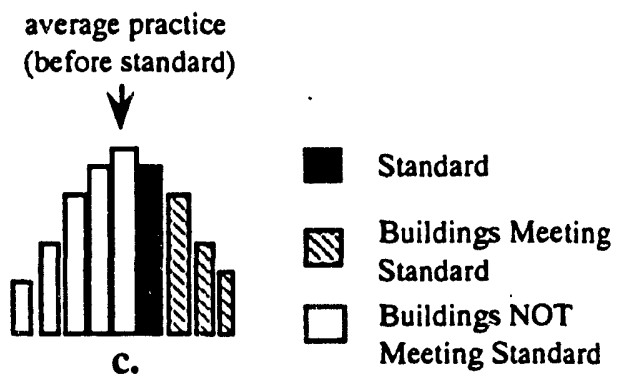


14. Did the following considerations influence the inclusion or exclusion of certain measures in the standard? (Check one box for each consideration and comment below.)
a. Cost effectiveness
$\square$ Yes
$\square \mathrm{No}$
Uncertain
b. Market or local availability of
$\square$ Yes
No
Uncertain energy efficient products
c. Similarity/difference to local design practice

$\begin{array}{ll}\square \text { Yes } & \square \text { No } \\ \square \text { Yes } & \square \text { No }\end{array}$
$\square$ Uncertain
d. Comfort
e. Other (Please specify below):

\section{COMMENTS:}

15. Energy standards are often revised and updated to reflect technological improvements.

a. Is the standard in your country scheduled for regular REVIEW and REVISION?
a No (Go to Question 16)
$\square$ Yes - Please describe process below:

b. Does the revision process include procedures to MONITOR and EVALUATE the success of EARLIER VERSIONS of the standard?

口 No (Go to Question 16)

$\square$ Yes - Please describe procedures below: 


\section{SECTION IV: IMPLEMENTATION AND COMPLIANCE}

16. In many cases, building energy standards are added to existing (non-energy) building standards. In other cases, governments have created new agencies to implement and enforce building energy standards.

How would you characterize the ENTITIES involved in IMPLEMENTING energy standards in your country? (Check all that apply.)

a. An EXISTING agency, made responsible for implementing building energy standards. The agency's primary focus prior to assuming responsibility for standards was: (Check one)

1. $\square$ Buildings

2. Energy

3. $\square$ Other: (please specify)

b. $\square$ A NEW and separate agency, (please specify), was formed in (year) to implement energy standards for buildings.

c. $\square$ The standards are voluntary; there is no government agency designated to implement them.

d. $\square$ Other NON-GOVERNMENT entity(ies) (e.g., energy utility, professional association) issues or implements the standard. (Please specify below):

17. Has formal TRAINING or EDUCATION about the standard been provided for architects, engineers, and other professionals?

$\square$ No (Go to Question 18.)

Yes - Please indicate all TRAINING/EDUCATIONAL aids used:
a. Written guidelines to assist with compliance procedure
$\square$ Yes
$\square$ No
Uncertain
b. Example calculations
$\square$ Yes
$\square$ No
$\square$ Uncertain
c. Compliance forms
$\square$ Yes
$\square$ No Uncertain
d. Workshop(s), seminars(s), or
$\square$ Yes
No Uncertain conference(s)
e. Information or resource center
$\square$ Yes
$\square$ No
Uncertain
f. Other (Please describe below): 
18. Both mandatory and voluntary standards often have mechanisms to encourage compliance. Such mechanisms can be designed as positive incentives and/or penalties, and they can apply at several different stages of the design and construction process.

a. What COMPLIANCE MECHANISMS are used in your country, and at what stage in the construction process are they directed? (More than one term may apply.)

Compliance Mechanisms:
$\mathbf{C}=$ Certification/approval
$\mathrm{N}=$ No mechanism
$I=$ Incentive (positive reward)
$\mathbf{O}=$ Other policy mechanism
$\mathbf{P}=$ Penalty (negative incentive)
? = Uncertain

Please CIRCLE all appropriate terms-- C, I, P, N, O, ?-- for each construction stage below:

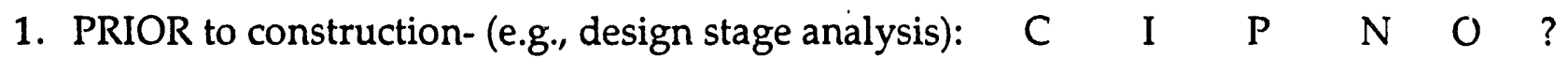
Approximately what percent of designs are checked? Comments:

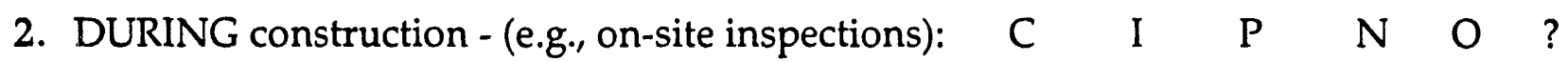
Approximately what percent of sites are checked? Ccmments:

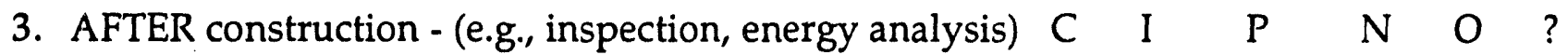
Approximately what percent of buildings are checked?

Comments:

4. Are there any OTHER procedures not related to a particular stage of the construction process (e.g., utility hook-up)? (Please specify.)

b. Overall, how effective do you feel the combined compliance mechanisms are at gaining compliance with the standard? (Circle one and comment below.)

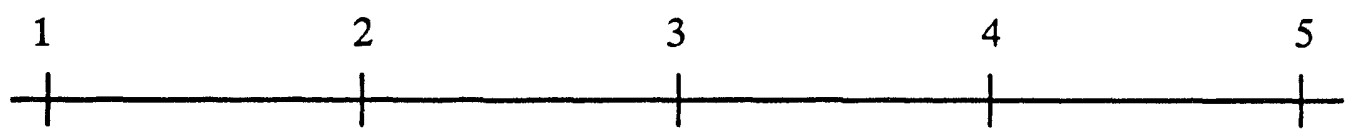

Not Effective

Somewhat Effective

Very Effective

Why? 
19. Have any of the following TYPES of ASSESSMENTS or audits of the impact from energy standards for buildings been conducted?

a. ENERGY SAVINGS POTENTIAL based on prototypical (not actual) buildings. (Check all that apply.)

1. $\square$ Completed $\rightarrow$ Please give reference information for any published results:

2. In progress

3. $\square$ Planned

4. $\square$ None conducted

b. MEASUREMENTS OF ENERGY SAVINGS in actual buildings complying with standard as compared to typical buildings. (Check all that apply.)

1. Completed $\rightarrow$ Please give reference information for any published results:

2. In progress

3. $\square$ Planned

4. $\square$ None conducted

c. COST EFFECTIVENESS based on engineering economic CALCULATIONS (i.e., simulation and modelling). (Check all that apply.)

1. $\square$ Completed $m$ Please give reference information for any published results:

2. In progress

3. $\square$ Planned

4. $\square$ None conducted

d. COST EFFECTIVENESS based on ACTUAL COSTS incurred and measured savings achieved (i.e., case studies). (Check all that apply.)

1. $\square$ Completed $\Rightarrow$ Please give reference information for any published results:

2. $\square$ In progress

3. $\square$ Planned

4. $\square$ None conducted

e. Other Assessments (please describe project goal and check current stage of completion):

1. $\square$ Completed $m$ Please give reference information for any published results:

2. $\square$ In progress

3. $\square$ Planned 


\section{SECTION V: FURTHER INFORMATION ON ENERGY CONSERVATION}

20. Are there EFFICIENCY TESTING FACILITIES and PROCEDURES established in your country for any of the following items? (Circle all that apply.)
a. Motors
Yes No ?
d. Ballasts
Yes No ?
b. Insulation
Yes No ?
e. Fixtures
Yes No?
c. Air conditioners/chillers/ other appliances
Yes No ?
f. Thermal properties Yes No ? of materials
g. Other (please specify):

21. To provide further information about the context of building energy issues in your country, please describe what OTHER PROGRAMS or POLICIES (besides standards) have been developed to INCREASE ENERGY EFFICIENCY in BUILDINGS. (e.g., energy utility initiatives, energy awareness campaigns, utility rebates, free or subsidized energy audits) Please list program type(s) and identify supporting organization(s):

Please suggest up to three ADDITIONAL SOURCES of information (i.e., books, periodicals, newspaper reports, or journal articles) about ENERGY EFFICIENCY for BUILDINGS in your country that could help provide a context for understanding this topic: (Please specify language of suggested reference material, English is preferred.)

1.

2.

3. 
22. If you answered Question 4, we would like to obtain a copy of the specified ENERGY STANDARD(s) itself and supporting documentation for it (in English if possible).

a. Whom should we contact to obtain a written copy of the ENERGY STANDARD(s) specified in Question 4? (Please provide name, mailing address, phone number, and fax number)

Name:

Address:

Tel:

Fax:

b. Please describe the types of SUPPORTING DOCUMENTATION available for this standard(s) and whom we should contact to obtain them: (If different from above, please provide name, mailing address, phone number, and fax number)

Types of Documentation:

Contact Name:

Address:

Tel:

Fax:

c. Are there any OTHER energy standard(s) for NON-RESIDENTIAL buildings in your country that were NOT specified in Question 4?

No (Go to Question 23.)

Yes Please specify OTHER energy standard(s) below and whom we should contact for more information: (Attach additional page if necessary)

1. Energy Standard Title:

Issuing Organization:

Contact Name:

Address:

Tel:

Fax:

2. Energy Standard Title:

Issuing Organization:

Contact Name:

Address:

Tel:

Fax: 
23. Are there OTHER PEOPLE or INFORMATION SOURCES in your country whom you feel should respond to the questions raised in this survey? If so, please list their names and/or titles and contact information below (attach additional page if necessary):

Contact Name:

Address:

Tel:

Fax:

Contact Name:

Address:

Tel:

Fax:

\section{FINISH}

Thank you for participating in this survey and contributing to our research. If you would like to receive a copy of our findings when we have compiled the results, check this box:

Survey completed by

Name:

Title:

Organization:

Address:

Tel:

Fax:

Date completed:

Please Return Survey (VIA telefax OR AIR MAIL) TO:

Kathryn Janda

Lawrence Berkeley Laboratory

Energy Analysis Program, MS 90-4000

Berkeley, CA 94720 USA

Tel: +1 510-486-5793

Fax: +1 510-486-6996

e-mail: kbjanda@dante.lbl.gov 


\section{APPENDIX B}

\section{Input Key}

and

Survey Data Table

This appendix abbreviates information gathered from all 59 surveys received. 
INPUT KEY FOR SURVEY DATA TABLE

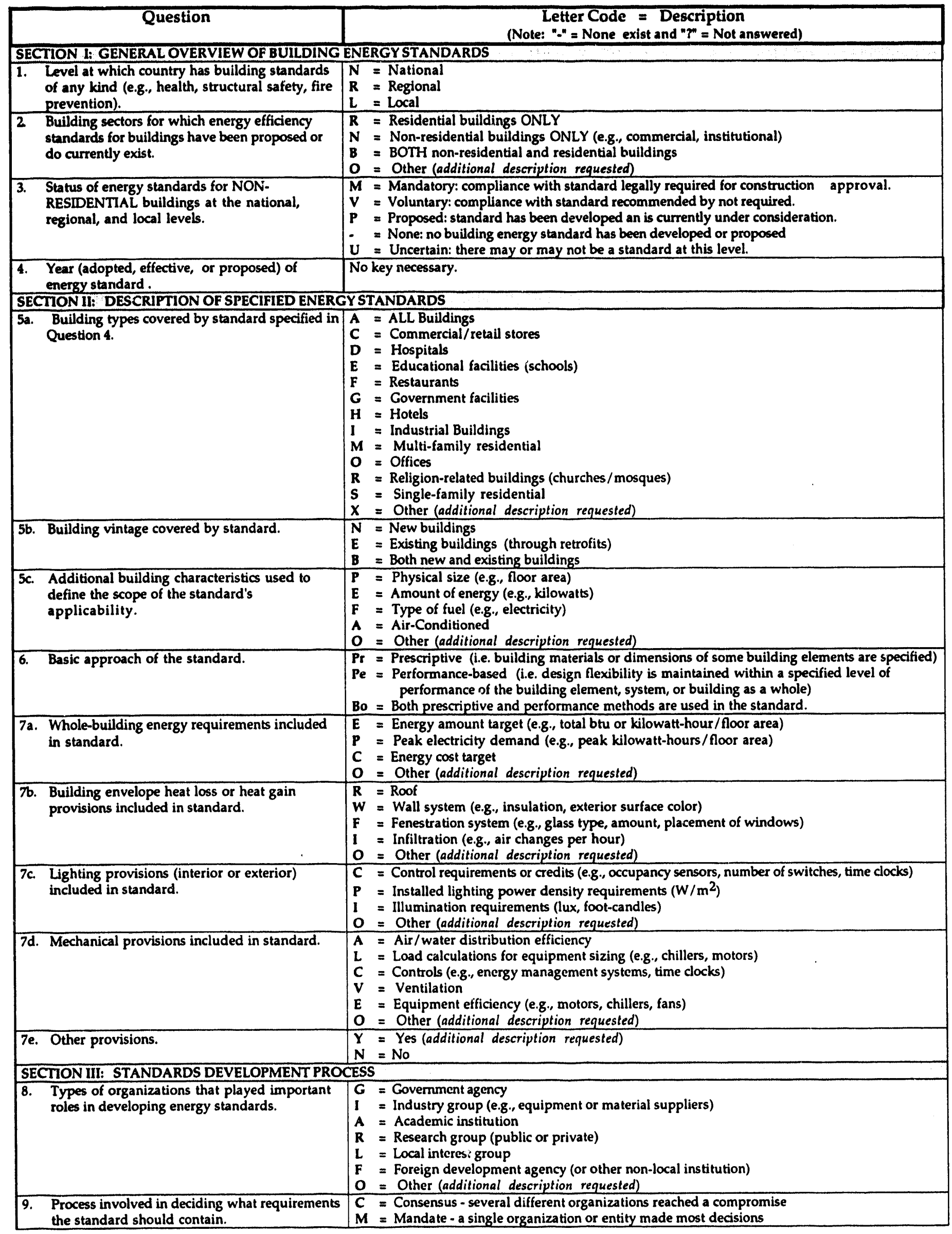




\begin{tabular}{|c|c|}
\hline $\begin{array}{l}\text { 10a. Information about physical characteristics of } \\
\text { existing buildings (e.g., size, function, types of } \\
\text { walls and windows) used. }\end{array}$ & $\begin{array}{l}\mathbf{N}=\text { Not available, and not used in standard. } \\
\mathbf{E}=\text { Estimated using professional judgment. } \\
\mathbf{G}=\text { Gathered through audits or surveys for the purpose of the standard. } \\
\mathbf{A}=\text { Already available prior to standard development. }\end{array}$ \\
\hline $\begin{array}{l}\text { 10b. Information about energy use of existing } \\
\text { buildings (e.g., annual consumption, peak } \\
\text { demand, load patterns). }\end{array}$ & $\begin{array}{l}\mathbf{N}=\text { Not available, and not used in standard. } \\
\mathbf{E}=\text { Estimated using professional judgment. } \\
\mathbf{C}=\text { Computer simulations used for estimates. } \\
\mathbf{G}=\text { Gathered through audits or surveys for the purpose of the standard. } \\
\mathbf{A}=\text { Already available prior to standard development. }\end{array}$ \\
\hline $\begin{array}{l}\text { 10c. Information about weather data (e.g., direct } \\
\text { and indirect solar radiation, temperature, } \\
\text { humidity). }\end{array}$ & $\begin{array}{l}\mathbf{N}=\text { Not available, and not used in standard. } \\
\mathbf{E}=\text { Estimated using professional judgment. } \\
\mathbf{C}=\text { Computer simulations used for estimates. } \\
\mathbf{G}=\text { Gathered through audits or surveys for the purpos } \% \text { of the standard. } \\
\mathbf{A}=\text { Already available prior to standard development. }\end{array}$ \\
\hline 10d. Other information? & $\begin{array}{l}\mathbf{Y}=\text { Yes (additional description requested) } \\
\mathbf{N}=\text { No }\end{array}$ \\
\hline 11. Standards from a different country used. & Name of country. \\
\hline 12a. Computer programs used to develop standard. & Name of program. \\
\hline 12b. Computer programs used for compliance. & $\begin{array}{l}\mathbf{Y}=\text { Yes } \\
\mathbf{N}=\text { No }\end{array}$ \\
\hline 13. Goal of standard & $\begin{array}{l}\mathrm{L}=\begin{array}{c}\text { The standard is set at a level LOWER than current practice to eliminate the most } \\
\text { inefficient building designs. }\end{array} \\
\mathrm{E}=\begin{array}{c}\text { The standard is set at a level approximately EQUAL to current practice to encourage } \\
\text { moderate levels of efficiency. }\end{array} \\
\mathrm{A}=\begin{array}{c}\text { The standard is set at a level ABOVE current practice to promote highly-efficient } \\
\text { buildings and encourage technological development. }\end{array}\end{array}$ \\
\hline $\begin{array}{l}\text { 14. Considerations influencing the inclusion or } \\
\text { exclusion of certain measures. }\end{array}$ & $\begin{array}{l}\mathbf{E}=\text { Cost effectiveness } \\
\mathrm{A}=\text { Market or local availability of energy efficient products } \\
\mathrm{S}=\text { Similarity/difference to local design practice } \\
\mathrm{C}=\text { Comfort } \\
\mathrm{O}=\text { Other (additional description requested) }\end{array}$ \\
\hline 15a. Provision for regular review. & $\begin{array}{l}\mathbf{Y}=\text { Yes (additional description requested) } \\
\mathbf{N}=\text { No }\end{array}$ \\
\hline $\begin{array}{l}\text { 15b. Revision includes, evaluation of earlier } \\
\text { standard. }\end{array}$ & $\begin{array}{l}\mathbf{Y}=\text { Yes (additional description requested) } \\
\mathbf{N}=\mathrm{No}\end{array}$ \\
\hline \multicolumn{2}{|c|}{ SECTION IV: IMPL ${ }^{\circ}$ MENTATION AND COMPLIANCE } \\
\hline $\begin{array}{l}\text { 16. Entities involved in implementing energy } \\
\text { standards. }\end{array}$ & \begin{tabular}{|l}
$\mathbf{E}=$ Existing agency \\
$\mathbf{N}=$ New and separate agency \\
$\mathbf{V}=$ Standards are voluntary; no implementation agency \\
$\mathbf{O}=$ Other (additional description requested)
\end{tabular} \\
\hline 16a. Former focus of existing agency. & $\begin{array}{l}\mathbf{B}=\text { Buildings } \\
\mathbf{E}=\text { Energy } \\
\mathbf{O}=\text { Other (additional description requested) }\end{array}$ \\
\hline $\begin{array}{l}\text { 17. Types of training and education provided for } \\
\text { architects, engineets, and other professionals. }\end{array}$ & $\begin{array}{l}\mathbf{W}=\text { Written guidelines to assist with compliance procedure } \\
\mathbf{E}=\text { Example calculations } \\
\mathbf{C}=\text { Compliance forms } \\
\mathbf{S}=\text { Seminars(s), workshop(s), or conference(s) } \\
\mathbf{I}=\text { Information or resource center } \\
\mathbf{O}=\text { Other (additional description requested) }\end{array}$ \\
\hline $\begin{array}{l}\text { 18. Compliance mechanisms before, during, and } \\
\text { after construction. }\end{array}$ & $\begin{array}{l}\mathbf{C}=\text { Certification/approval } \\
\mathbf{I}=\text { Incentive (positive reward) } \\
\mathbf{P}=\text { Penalty (negative incentive) } \\
\mathbf{N}=\text { No mechanism } \\
\mathbf{O}=\text { Other policy mechanism (additional description requested) } \\
?=\text { Uncertain }\end{array}$ \\
\hline 18d. Effectiveness of mechanisms & Scale of 1 (not effective) to 5 (very effective) \\
\hline $\begin{array}{l}\text { 19. Assessments conducted: } \\
\text { a. Energy savings potential } \\
\text { b. Measured energy savings } \\
\text { c. Calculated cost effectiveness } \\
\text { d. Actual cost effectiveness }\end{array}$ & $\begin{array}{l}\mathbf{C}=\text { Completed } \\
\mathbf{I}=\text { In progress } \\
\mathbf{P}=\text { Planned } \\
\mathbf{N}=\text { None conducted }\end{array}$ \\
\hline \multicolumn{2}{|c|}{ SECTION V: FURTHER INFORMATION ON ENERG Y CONSERVATION } \\
\hline $\begin{array}{l}\text { 20. Items for which efficiency testing facilities and } \\
\text { procedures exist. }\end{array}$ & $\begin{array}{l}\mathbf{M}=\text { Motors } \\
\mathbf{I}=\text { Insulation } \\
\mathbf{A}=\text { Air conditioners/chillers/other appliances } \\
\mathbf{B}=\text { Ballasts } \\
\mathbf{F}=\text { Fixtures } \\
\mathbf{T}=\text { Thermal properties of materials } \\
\mathbf{O}=\text { Other (additional description requested) }\end{array}$ \\
\hline $\begin{array}{l}\text { 21. Other programs or policies developed to } \\
\text { increase energy efficiency in buildings. }\end{array}$ & $\begin{array}{l}\mathbf{U}=\text { Utility initiatives } \\
\mathbf{I}=\text { Information programs } \\
\mathbf{R}=\text { Rebates } \\
\mathbf{A}=\text { Audits (free or subsidized) } \\
\mathbf{B}=\text { Building energy standards } \\
\mathbf{T}=\text { Time of day pricing } \\
\mathbf{L}=\text { Labeling of appliances } \\
\mathbf{G}=\text { Government energy policy } \\
\mathbf{O}=\text { Other (additional description requested) }\end{array}$ \\
\hline
\end{tabular}


Survey Data Table (all 59 Respondents)

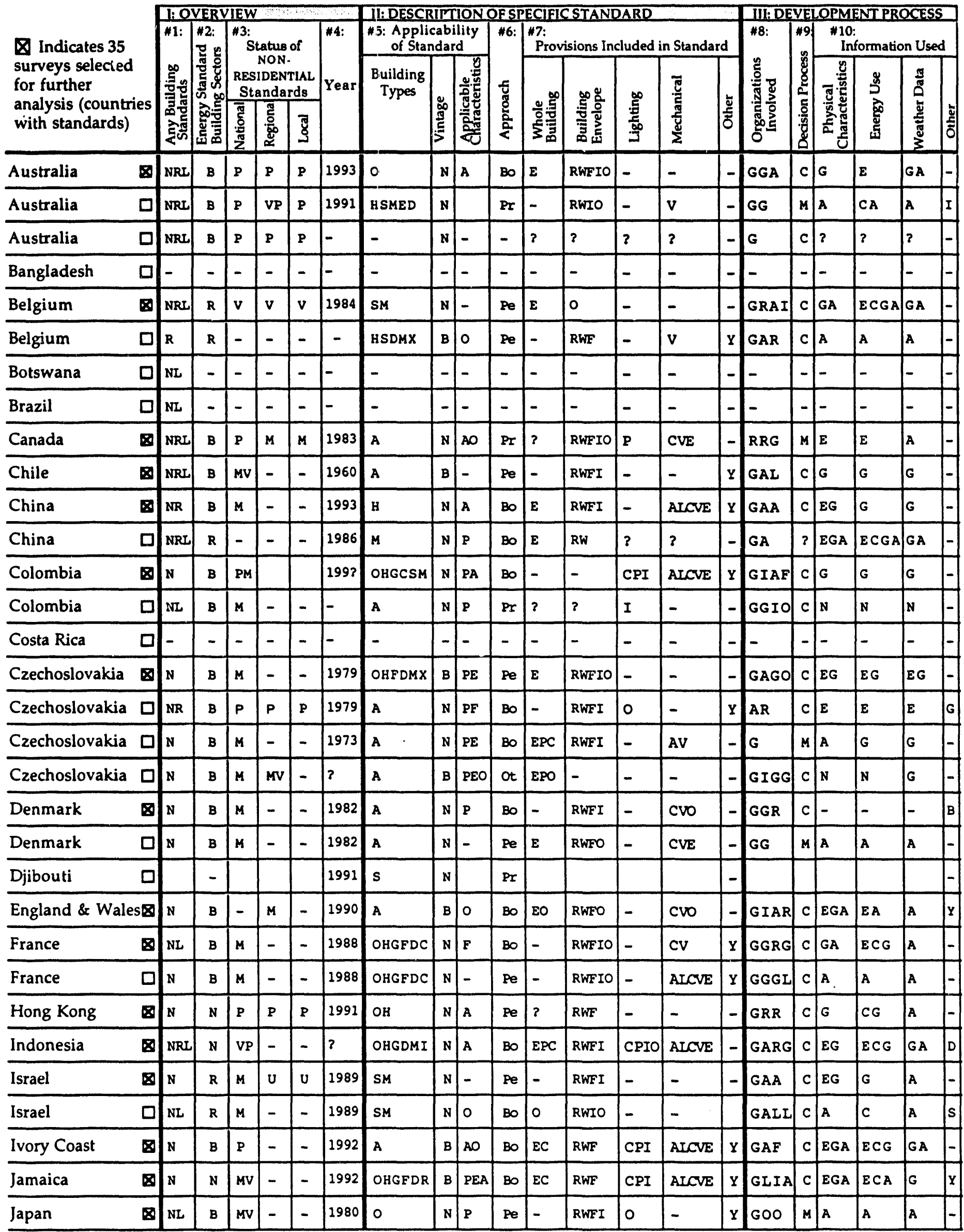


Survey Data Table (cont)

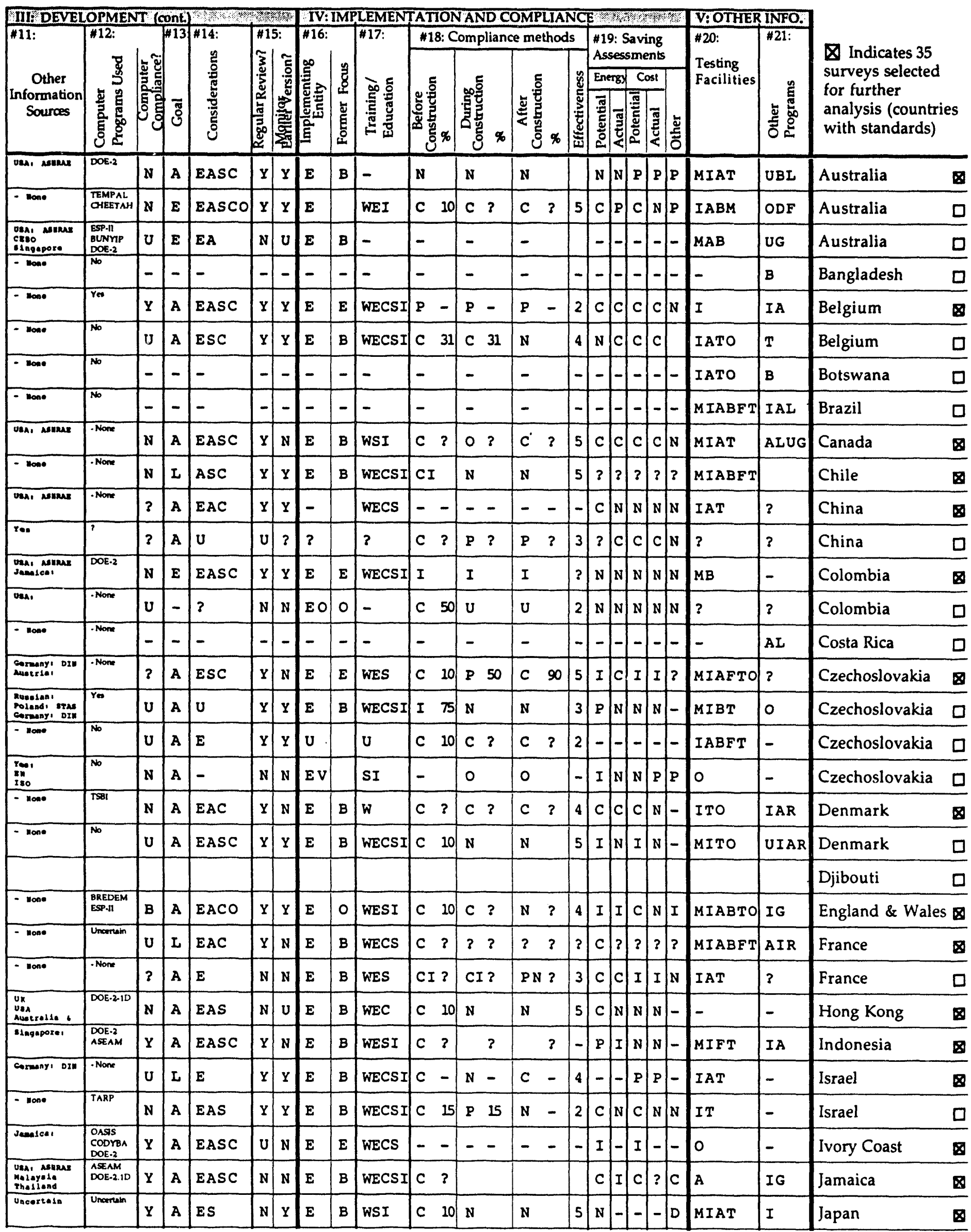


Survey Data Table (all 59 Respondents)

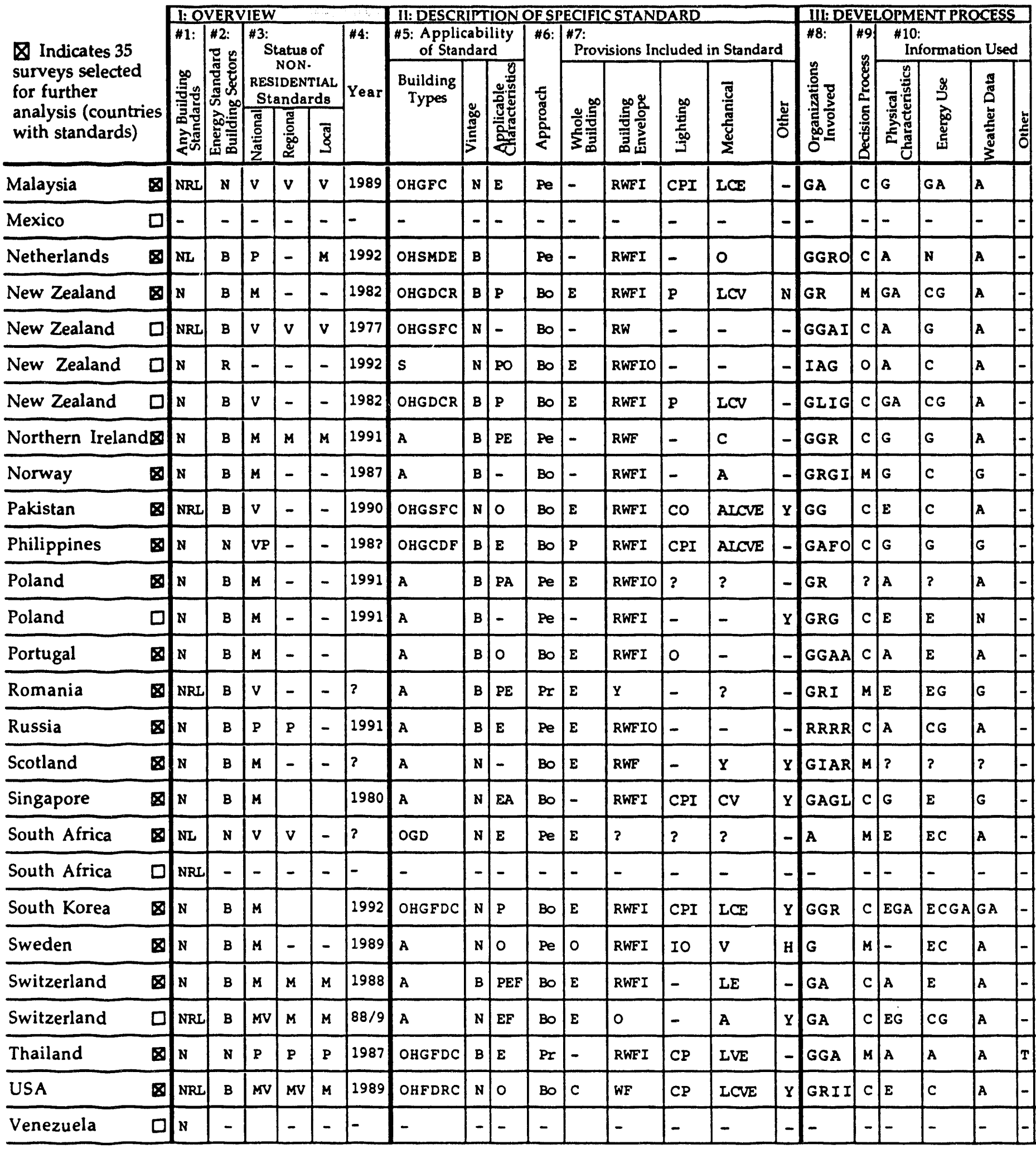


Survey Data Table (cont.)

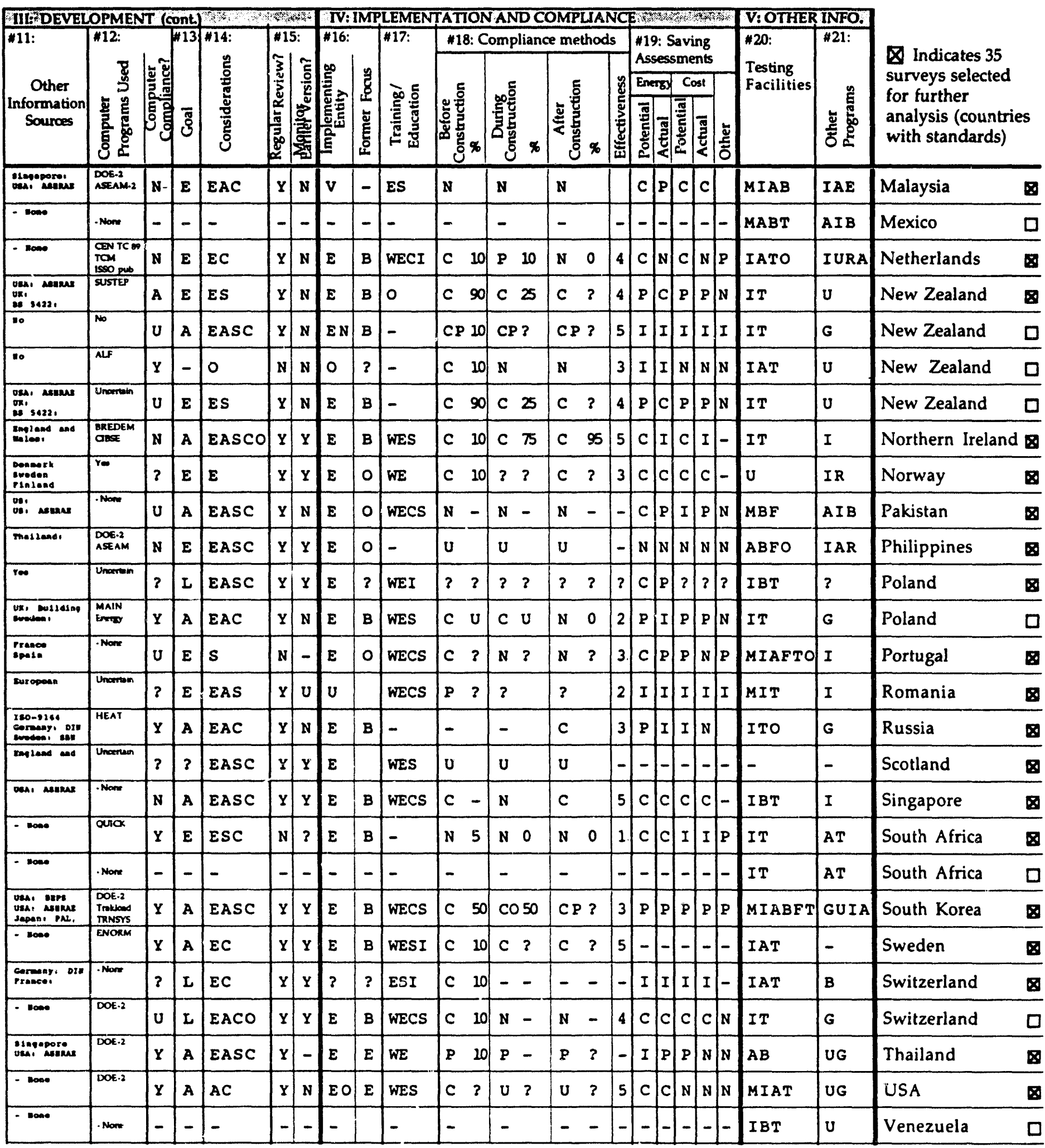




\section{APPENDIX C \\ Surveyed Details of Selected Energy Standards in 35 Countries}

\begin{tabular}{|c|c|}
\hline \\
\hline \multicolumn{2}{|c|}{ Belgium } \\
\hline \multicolumn{2}{|c|}{ 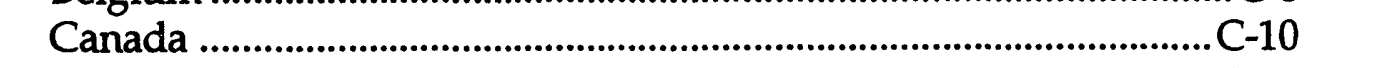 } \\
\hline \multicolumn{2}{|c|}{ Chile } \\
\hline \multicolumn{2}{|c|}{ 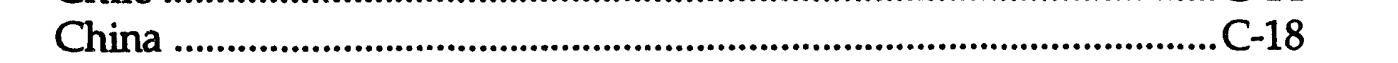 } \\
\hline \multicolumn{2}{|c|}{ Colombia } \\
\hline \multicolumn{2}{|c|}{ Czechoslovakia (former) } \\
\hline \multicolumn{2}{|c|}{ Denmark } \\
\hline \multicolumn{2}{|c|}{ England \& Wales } \\
\hline \multicolumn{2}{|c|}{ 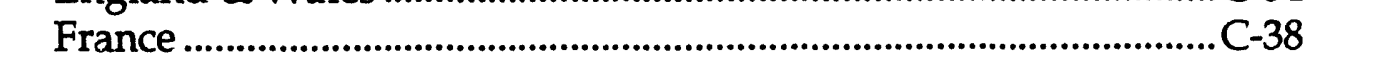 } \\
\hline \multicolumn{2}{|c|}{ 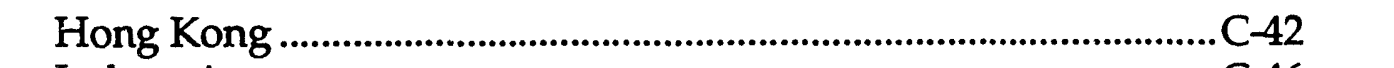 } \\
\hline \multicolumn{2}{|c|}{ Indonesia } \\
\hline \multicolumn{2}{|c|}{ Israel } \\
\hline \multicolumn{2}{|c|}{ Ivory Coast } \\
\hline \multicolumn{2}{|c|}{ Jamaica } \\
\hline \multicolumn{2}{|c|}{ Japan } \\
\hline \multicolumn{2}{|c|}{ 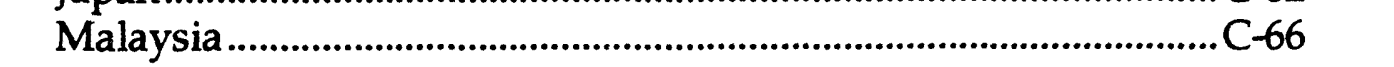 } \\
\hline \multicolumn{2}{|c|}{ 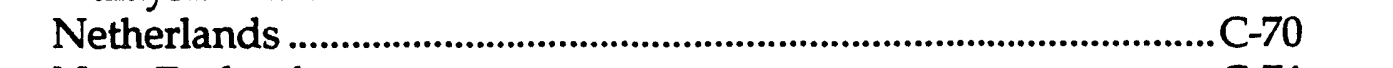 } \\
\hline \multicolumn{2}{|c|}{ 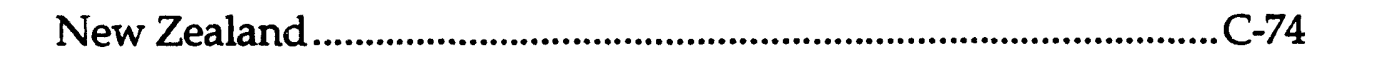 } \\
\hline \multicolumn{2}{|c|}{ Northern Ireland } \\
\hline \multicolumn{2}{|c|}{ Norway } \\
\hline \multicolumn{2}{|c|}{ 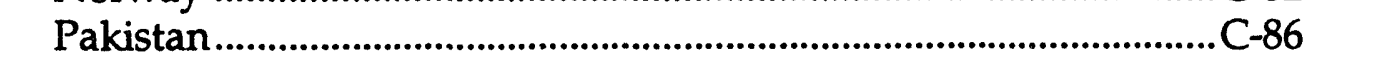 } \\
\hline \multicolumn{2}{|c|}{ Philippines } \\
\hline \multicolumn{2}{|l|}{ Poland ...... } \\
\hline \multicolumn{2}{|c|}{ 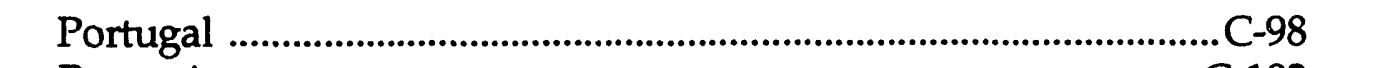 } \\
\hline \multicolumn{2}{|c|}{ 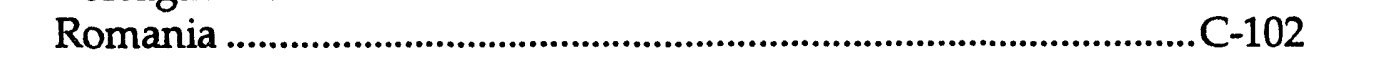 } \\
\hline \multicolumn{2}{|c|}{ Scotland } \\
\hline \multicolumn{2}{|c|}{ 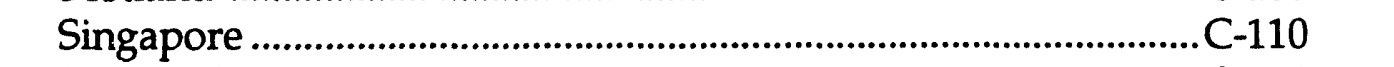 } \\
\hline \multicolumn{2}{|c|}{ South Africa } \\
\hline \multicolumn{2}{|c|}{ 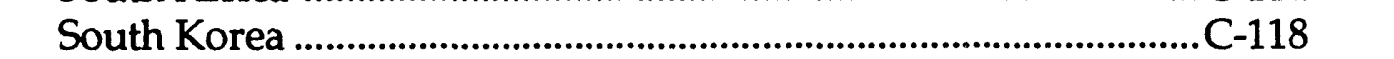 } \\
\hline \multicolumn{2}{|c|}{ Sweden } \\
\hline Switzerland & ...C-126 \\
\hline Thailand & ....C-130 \\
\hline & $. . C-1$ \\
\hline & \\
\hline
\end{tabular}

In most cases only one survey from each country was received, but in cases where multiple surveys were returned we did not attempt to verify or "correct" discrepancies between respondents from the same country. To develop our comparative analysis set and this appendix, we selected the surveys which seemed to contain the most reliable information. 


\section{GENERAL OVERVIEW OF BUILDING ENERGY STANDARDS}

1. General building standards exist at the following govemmental levels:

Regional

Local

2. Proposed or existing ENERGY standards cover the following building sectors: Both Residential and Non-Residential

3. Status of Non-Residential Building Energy Standards at the:

a National level:

Proposed

b. Regional level:

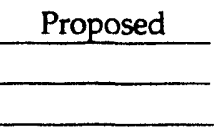

c. Local level:

4. Single energy standard selected for further description:

Title, Organization: Building Envelope, Australian Standards Association

Year: 1993 Geographic Coverage: Nation Abbreviated Title: ASA-1993

\section{DESCRIPTION OF SPECIFIED ENERGY STANDARDS - ASA-1993}

5. The standard defined in Question 4 applies to the following kinds of buildings:

a. Building types:

Offices

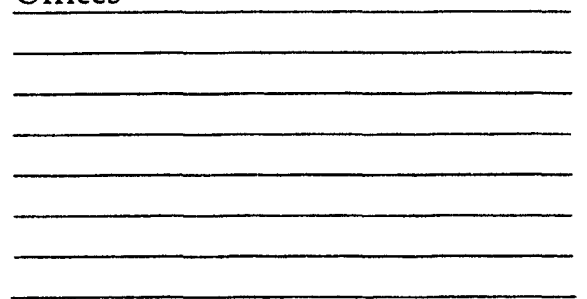

b. Building vintage:

New buildings

c. Other characteristics:

A - Air-Conditioned

6. Basic approach of the standard: Both prescriptive and performance

7. The following subjects are included in the energy standard:

a. Whole building energy provisions:

E- Energy amount target

\section{c. Lighting provisions:}

- None

e. Other provisions:

-None b. Building envelope provisions:

Roof

Wall system

Fenestration system

Infiltration

Other: Thermal mass, internal load

d. Mectanical provisions:

- None 
STANDARDS DEVELOPMENT PROCESS - ASA-1993

AUSTRALIA 2

\section{Organizations involved in developing the standard:}

Government agency: Energy Research and Development Cooperation

Government agency: Standards Association, Australia

Academic institution: SOLARCH, University of New South Wales

9. Decision Process: Consensus

Comment

10. Information used in developing the standard:

a. PHYSICAL CHARACTERISTICS of existing buildings

Gathered through audits and surveys

\section{c. WEATHER data}

Gathered through measurements Already available prior to standard

11. Standards from a different country used as source material:

USA: ASHRAE 90.1-1989

\section{b. ENERGY USE of existing buildings:}

Estimated using professional judgment

\section{d. Other information}

-None

12. COMPUTER programs used:

a In developing the standard:

DOE-2

b. For complying with the standard: No

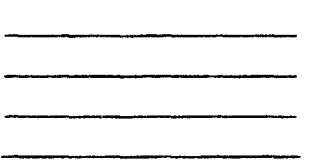

13. Standard is set at a level: Above current practice

14. Considerations influencing the inclusion or exclusion of measures in the standard:

E - Cost effectiveness

Availability of energy efficient products

Similarity/difference to local design

Comfort

Comments:

\section{5a. Standard scheduled for regular review and revision?}

Yes:Standards Australia committees initiate these--often the professional drive it ton.

b. Does revision include procedures to MONTOR and EVALUATE earlier versions of the standard?

Yes

$$
\text { C. } 3
$$


16. Entities involved in IMPLEMENTING energy standards:

Existing agency: Standards Australia

If an existing agency was made responsible for implementation, its former focus was on buildings, energy, or another area:

Buildings

17. TRAINING \& EDUCATION provided for architects, engineers and other professionals:

- None

18. Compliance mechanisms used at different stages in construction process:

a. PRIOR to construction

No mechanism

Percent designs checked:

Comment:

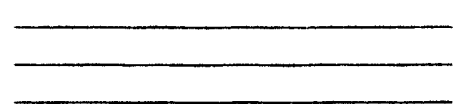

b. DURING construction:

No mechanism

No mechanism

Percent sites checked:

Comment:

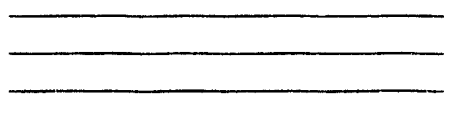

\section{c. AFTER construction:}

No mechanism

Percent buildings checked:

Comment:

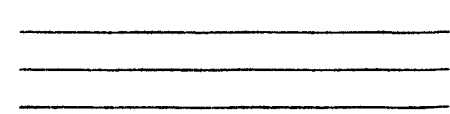

d. Other compliance procedures Some councils (local governments) are encouraging use of standards.

e. Effectiveness of combined compliance mechanisms (scale of 1-5):

f. Explanation for effectiveness in part e:

19. Types of assessments or audits of energy standards' impact:

a. ENERGY SAVINGS POTENTIAL based on prototypical (not actual) buildings:

None conducted

b. MEASUREMENTS OF ENERGY SAVINGS in actual buildings complying with standard:

None conducted

c. COST EFFECTIVENESS based on engineering economic CALCULATIONS:

Planned

d. COST EFFECTIVENESS based on ACTUAL COSTS:

Planned

e. Other Assessments: Planned 


\section{FURTHER INFORMATION ON ENERGY CONSERVATION - AustraLIa}

20. Efficiency testing facilities and procedures established:

Motors

Insulation

Air conditioners/chillers/other appliances

Thermal properties of materials

21. Other programs or policies developed to increase energy efficiency in buildings:

Utility initiatives

Building energy standards

Labeling of appliances

\section{Additional sources of information about energy efficiency for buildings in: A ustralia}

1. E.R.D.C. Compendium (P.). Box 629; Canberra, ACT. 2601, Australia)

2. A.N.Z.S.E.S. (Australia New Zealand Solar Energy Society) Proceedings of conferences.

3. AlRAH (Australian Institute of Refrigeration, Air-Conditioning, and Heating) Journal

\section{Contact for written copy of energy standard specified in Question 4:}

Name Deo K. Prasad

Address: $\quad$ Associate Director, SOLARCH

P.O. Box 1

Kensington 2033

Country: Australia
Tel:
$61-2-697-4868$
Fax:
$61-2-662-1378$

Comment Building energy targets developed by B.D.M.A.

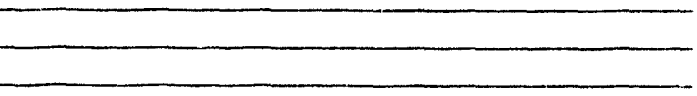

Types of supporting information available:

Other energy standards for non-residential buildings:

Survey completed by: Deo K. Prasad

Title: Associate Director, SOLARCH

University of New South Wales

P.O. Box 1, Kensington

New South Wales

2033 Country: Australia

Tel: $\quad 61-2-697-4868 \quad$ Fax: $61-2-662-1378$

Date completed: $\quad 4 / 14 / 92$ 


\section{GENERRLOVEAVIEW OFBUILDING ENERGY STANDARDS}

1. General building standards exist at the following governmental levels:

National

Regional

Local

2 Proposed or existing ENERGY standards cover the following building sectors: Residential Only

3. Status of Non-Residential Building Energy Standards at the:

a. National level: Voluntary

b. Regional level: Voluntary

c. Local level: Voluntary

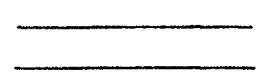

4. Single energy standard selected for furtter description:

Titte, Organization: Réglementatin thermique pour les logements neufs (KZO-Be500) 1984. Ministere de la Regin Wallonne

Year: 1984 Geographic Coverage: Regions Abbreviated Title: K70-BE500:1984

\section{DESCRIPTION OF SPECIFIED ENERGY STANDARDS - K70-BE500:1984}

5. The standard defined in Question 4 applies to the following kinds of buildings:

a. Building types:

$S$ - Single-family residential

M - Multi-family residential

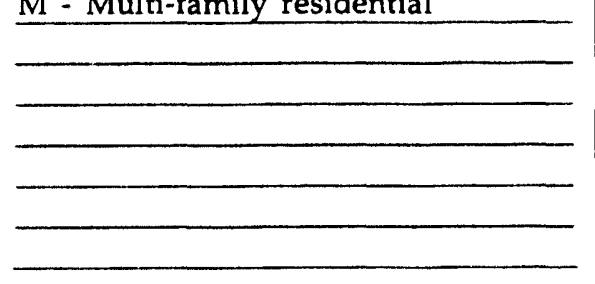

b. Building vintage:

New buildings

c. Other characteristics:

- Nor

6. Basic approach of the standard: Performance-based

7. The following subjects are included in the energy standard:

a Whole building energy provisions:

E- Energy amount target

c. Lighting provisions:

- None

e. Other provisions:

\section{b. Building emvelope provisions:}

Other: performance thermique de l'envelope (globale)

d. Mechanical provisions:

- None 


\section{STANDARDS DEVELOPMENT PROCESS - K70-BE500:1984}

\section{Organtzations involved in developing the standard:}

Government agency: Ministere de la Région Wallonne

Research group: C.S.T.C.

Academic institution: U. Lg, U.C.L, U.M.S.

Industry group: Ordre des architectes; COMITA (isolarits); verries etc.

\section{Decision Process: Consensus}

comment

10. Information used in developing the standard:

a. PHYSICAL CHARACTERISTICS of existing buildings

Gathered through audits and surveys Already available prior to standard

\section{WEATHER data}

Gathered through measurements Already available prior to standard

11. Standards from a different country used as source material:

- None

\section{b. ENERGY USE of existing buildings:}

Estimated using professional judgment Computer simulations used for estimates Gathered through audits and surveys Already available prior to standard

\section{d. Other information}

-None.

12. COMPUTER programs used:

a. In developing the standard: Yes

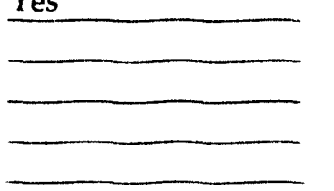

b. For complying with the standard: Yes

13. Standard is set at a level: Above current practice

\section{Considerations influencing the inclusion or exclusion of measures in the standard:}

E - Cost effectiveness

Availability of energy efficient products

Similarity/difference to local design

Comfort
Comments:

\section{5a. Standard scheduled for regular review and revision?}

Yes: nouvelles normes pour le esleuf des coefficients, ventilatin tec performance des vitrages

b. Does revision include procedures to MONITOR and EVALUATE earlier versions of the standard?

Yes 


\section{MPLEMENTATION AND COMPLIANCE - K70-BE500:1984}

16. Entties involved in MMPLEMENTING energy standards:

Existing agency: Ministere de la Region Wallonnne D.G.C.R.

If an existing agency was made responsible for implementation, its former focus was on buildings, energy, or another area:

Energy

17. TRANING \& EDUCATION provided for archittects, engineers and other professionals:

Written guidelines to assist with compliance procedure

Example calculations

Compliance forms

Seminars, workshops, or conferences

Information or resource center

18. Compliance mechanisms used at different stages in construction process:

a. PRIOR to construction:

Penalty

Percent designs checked:

Comment: b. DURING construction:

Penalty

Percent sites checked:

Comment: c. AFTER construction:

Penalty

Percent buildings checked:

Comment:

d. Other compliance procedures -None

e. Eflectiveness of combined compliance mechanisms (scale of 1-5): 2

f. Explanation for effectiveness in part e:

19. Types of assessments or audits of energy standards' impact:

a. ENERGY SAVINGS POTENTIAL based on prototypical (not actual) buildings:

Completed

b. MEASUREMENTS OF ENERGY SAVNGS in actual buildings complying with standard:

Completed

c. COST EFFECTIVENESS based on engineering economic CALCULATIONS:

Completed

d. COST EFFECTIVENESS based on ACTUAL COSTS:

Completed

e. Other Assessments: None conducted 


\section{FURMHER INFOAIATION ON ENERGY CONSERVATION - Belgium}

20. Efficiency testing facilties and procedures establiahed:

Insulation

21. Other programs or policies developed to increase energy efficiency in bullings:

Information programs

Audits (free or subsidized)
Comment Campagne cornet d'epoigne energie (habitat existent); guichets de l'energie; A geela EPEE. logements soliare, ecoles-hopitaux, lieux de cultes (diagnostics thermiques)

\section{Additional sources of information about energy efficiency for bulldings in: Belgium}

1. Bilan energetique de la Walemie. Tableau de borol

2. Applicatin de la réglementatin $K 90-B e 500$

3. Ecrnatec: rentabilite des investissements URE pour le lagement existant.

22. Contact for written copy of energy standard specified in Question 4:

Name:

Address: Ministere de la Région Wallonne D.G.T.R.

direction de l'energie

avenue Prince de Liege, 7

5100 Namur (Jambes)

Country: Belgium

Tel: $\quad 3281321541$

Fax: $\quad 3281306600$

Types of supporting information available:

-None

Other energy standards for non-residential buildings:

-None

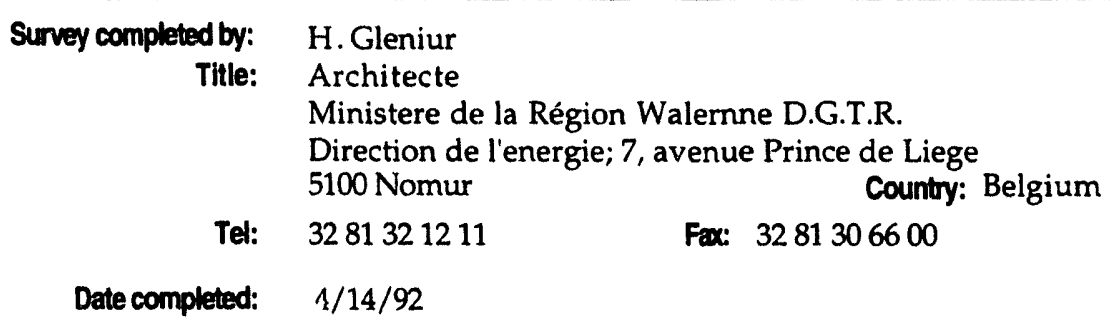


1. Cenerd builing standards exist at the following govemmental levels:

National

Regional

Local

2. Proposed or existing ENERGY standards cover the following building sectors: Both Residential and Non-Residential

3. Status of Non-Residential Builling Energy Standards at the:

a. National lovel:

Proposed

b. Regional lovel:

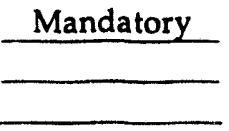

c. Local level: Mandatory

\section{Single energy standard selected for further description:}

Thte, Organization: Loisur l'économie de l'énergie dans le Bâitiment Loi son Régleglément sur l'économie de L'énergie dans les nowveaux Bâtiments. Ministeres de l'energie et des resources et celui du Iravail. (National Research Council of Canada)

Year: 1983 Ceographic Coverage: __ Regions _ Abbreviated Title: NRCC-22432

\section{DESCAIPTION OF SPECIFIED ENERGY STANDARDS - NRCC-22432}

5. The standard defined in Question 4 applies to the following kinds of buildings:

a. Building types:

A - All Buildings

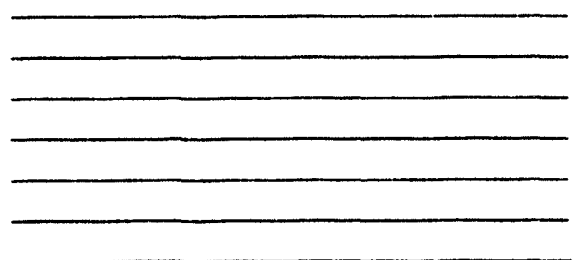

b. Building vintage:

New buildings

c. Other characteristics:

A - Air-Conditioned

$\mathrm{O}$ - Other: heating systems

6. Basic approach of the standard: Prescriptive

7. The following subjects are included in the energy standard:

a. Whole bulding energy provisions:

? - Uncertain

\section{c. Lighting provisions:}

Power density

e. Other provisions:

-None

\section{b. Bulling envelope provisions:}

Roof

Wall system

Fenestration system

Infiltration

Other: thermal properties of materials

d. Mechanical provisions:

Controls

Ventilation

Equipment efficiency 


\section{Organtzations involved in developing the standard:}

Research group: Canadian National Research Council

Research group: ASHRAE with the standard 90A-1980

Government agency: Bureau de l'efficacite Enèrgétique

9. Decision Process: Mandate

Comment

10. Information used in developing the standand:

a. PHYSICAL CHARACTERISTICS of existing buildings

Estimated using professional judgment

\section{c. WEATHER data}

Already available prior to standard

11. Standards from a different country used as source material:

USA: ASHRAE 90A-1980

\section{b. ENERGY USE of existing bulldings:}

Estimated using professional judgment

\section{d. Other information}

-None
12. COMPUTER prograns used:

a In developing the standard: - None

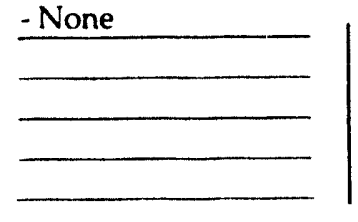

b. For complying with the standard: No

13. Standard is set at a level: Above current practice

14. Considerations influencing the inclusion or exclusion of measures in the standard:

E - Cost effectiveness

A - Availability of energy efficient products

S - Similarity/difference to local design

C. Comfort

Comments:

\section{5a. Standard scheduled for regular review and revision?}

Yes: with the CNRC's evaluation of ASHRAE 90.1-1989 and correction for Canada

b. Does revision include procedures to MONITOR and EVALUATE earlier versions of the standard?

$\mathrm{No}$ 


\section{CANADA}

\section{IMPLEMENTATION AND COINPLANCE. NRCC-22432}

16. Entities involved in IMPLEMENTING energy standards:

Existing agency: Régie du Bâtiment

If an existing agency was made responsible for implementation, its former focus was on buildings, energy, or another area:

Buildings

17. TRANING \& EDUCATION provided for architects, engineers and other professionals:

Written guidelines to assist with compliance procedure

Seminars, workshops, or conferences

Information or resource center

18. Compliance mechanisuns used at different stages in construction process:

a. PRIOR to construction:

Certification/approval

Percent designs checked: ?

Comment b. DURING construction:

Other policy mechanism

Percent sites checked: ? Comment:

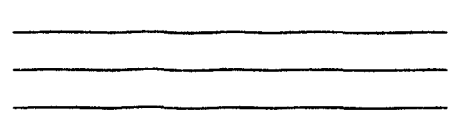

c. AFTER construction:

Certification/approval

Percent buildings checked: ?

Comment:

d. Other compliance procedures Yes: (see below)

e. Effectiveness of combined compliance mechanisms (scale of 1-5): 5

f. Explanation for effectiveness in part e: Builders, architects, and engineers must give a "conform certificate" to the owner.

19. Types of assessments or audits of energy standards' impact:

a. ENERGY SAVINGS POTENTIAL based on prototypical (not actual) buildings:

Completed

b. MEASUREMENTS OF ENERGY SAVNGS in actual buildings complying with standard:

Completed

c. COST EFFECTIVENESS based on engineering economic CALCULATIONS:

Completed

d. COST EFFECTIVENESS based on ACTUAL COSTS:

Completed

e. Other Assessments: None conducted 


\section{FURTIER NFORMATION ON ENERGY CONSERVATION - Canada}

\section{Efficiency testing facilities and procedures established:}

\section{Motors}

Insulation

Air conditioners/chillers/other appliances

Thermal properties of materials

\section{Other programs or policies developed to increase energy efficiency in buildings:}

Audits (free or subsidized)

Labeling of appliances

Utility initiatives

Government energy policy
Comment Bureau de l'efficacite energetique, and Hydro-Quebec.

\section{Additional sources of information about energy efficiency for buildings in: Canada}

1. La Maîtrise de l'energie. Association Québécoise pour la maîtrise de l'energie (AQME) 5. Place Ville-Marie, 9e étage, Bureau 903. Montreal, Quebec. H3B 2G2 Canada

2.

3.

22. Contact for written copy of energy standard specified in Question 4:

Name:

Address:

Les Publications du Québec

3, Complexe des Jardins

H5B 13E Quebec

Country: Canada

Tel: $\quad 5148736101$

Fax: $\quad 514873-0369$

Types of supporting information available:

"Reglement Commenté" (New edition will be available: Autumn 1992 from les publications du Québec)

Other energy 3tandards for non-residential buildings:

Energy Efficiency of Electrical and Hydrocarbon-Fueled Appliances Law.

Survey completed by: Jean-Pierre Roy

Title: Chef de Division: Conseils

Bureau de l'efficacité énergétique

425 Ave. Viger Ouest, Bureau 600

Montreal, H2Z 1W9

Country: Canada

Tel: $514-873-5463 \quad$ Fax: $514-873-6946$

Date completed: $\quad 7 / 13 / 92$ 


\section{GENERHL OVERWEW OFBULDING ENERGY STANDARDS}

1. Generd buining stenderds exist at the following govemmental levels:

\begin{tabular}{l|l|l|l|} 
National & Regional & Local
\end{tabular}

2. Proposed or existing ENERGY standards cover the following building sectors: Both Residential and Non-Residential

3. Status of Non-Residential Buliding Energy Standards at the:

Voluntary

b. Regional leve.

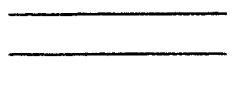

c. Local level:

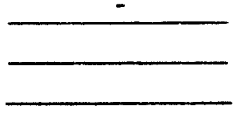

4. Single energy standard seleciled for further description:

Tite, Organization: Nch 1029 y Wch 1960

Year: 1900

Geographic Coverage: Nation

Abbreviated Titte: Nch 1029 y Wch1960

\section{DESCRIPTION OF SPECIFIED ENERGY STANDARDS - Nch 1029 y Wch1960}

5. The standard defined in Cuestion 4 applies to the following kinds of buildings:

\section{Building types:}

A - All Buildings

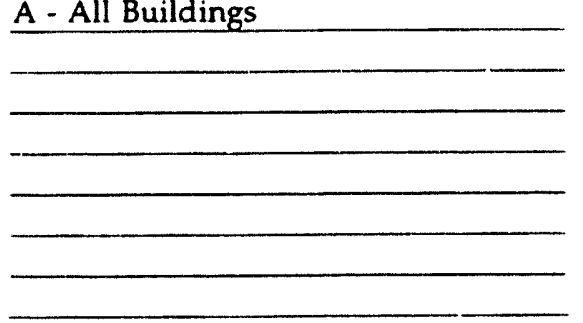

b. Building vintage:

Both new and existing

c. Other characteristics:

- None

6. Basic approach of the standard: Performance-based

7. The following subjects are inctuded in the energy standard:

a Whole buiding energy provisions:

- None

c. Lighting provisions:

- None

e Other provisions:

b. Buiding envelope provisions:

Roof

Wall system

Fenestration system

Infiltration

d. Mechenical provisions:

- None

C. 14 


\section{Organizations involved in developing the standard:}

Government agency: Institute Nacional Normalizacion

Academic institution: Universidades

Local interest group

9. Decision Process: Consensus

Comment

10. Information used in developing the standard:

a. PHYSICAL CHARACTERISTICS of existing buildings

Gathered through audits and surveys

\section{c. WEATHER data}

Gathered through measurements

11. Standards from a different country used as source material:

- None

\section{b. ENERGY USE of existing buildings:}

Gathered through audits and surveys

\section{d. Other information}

- None

12. COMPUTER programs used:

a In developing the standard:

- None

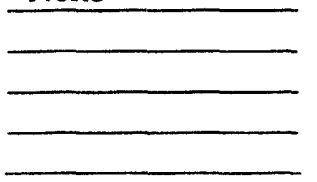

b. For complying with the standard: No

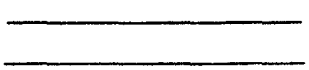

13. Standard is set at a level: Lower than current practice

14. Considerations influencing the inclusion or exclusion of measures in the standard:

Availability of energy efficient products Similarity/difference to local design Comfort

15a. Standard scheduled for regular review and revision?

Yes

b. Does revision include procedures to MONITOR and EVALUATE eartier versions of the standard?

Yes
Comments:

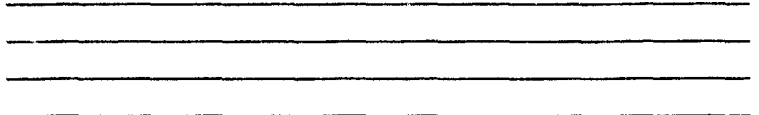


16. Entities involved in IMPLEMENTING energy standards:

Existing agency: Instituto Nacional de Normalizacion

If an existing agency was made responsible for implementation, its former focus was on buildings, energy, or another area:

Buildings

17. TRAINING \& EDUCATION provided for architects, engineers and other professionals:

Written guidelines to assist with compliance procedure

Example calculations

Compliance forms

Seminars, workshops, or conferences

Information or resource center

18. Compliance mechanisms used at different stages in construction process:

a. PRIOR to construction:

Certification/approval

Incentive

Percent designs checked:

Comment:

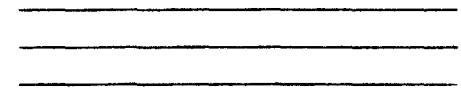

b. DURING construction:

No mechanism

Percent sites checked

Comment:

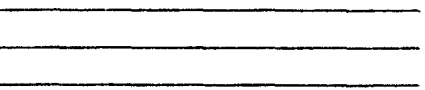

C. AFTER construction:

No mechanism

Percent buildings checked:

Comment:

\section{d. Other compliance procedures}

e. Effectiveness of combined compliance mechanisms (scale of 1.5): 5

f. Explanation for effectiveness in part e:

19. Types of assessments or audits of energy standards' impact:

a. ENERGY SAVINGS POTENTIAL based on prototypical (not actual) buildings:

?

b. MEASUREMENTS OF ENERGY SAVINGS in actual buildings complying with standard:

?

c. COST EFFECTIVENESS based on engineering economic CALCULATIONS:

$?$

d. COST EFFECTIVENESS based on ACTUAL COSTS:

?

e. Other Assessments: ? 


\section{FURTHER INFORMATION ON ENERGY CONSERVATION - ChIL}

20. Efficiency testing facilities and procedures established:

Motors

Insulation

Air conditioners/chillers/other appliances

Ballasts

Fixtures

Thermal properties of materials

21. Other programs or policies developed to increase energy efficiency in buildings:

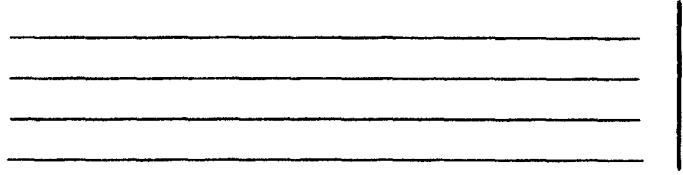

Comment

Additional sources of information about energy efficiency for buildings in: Chile

1.

2.

3.

22. Contact for written copy of energy standard specified in Question 4:

Name:

Address:

Country:

Tel:

Fax:

Types of supporting information available:

Other energy standards for non-residential buildings:

Survey completed by: Gabriel Rodriguez

Title: Engineer

IDIEM, University of Chile

Beaucheff 850

Tel: $\quad 562-698-2071 \times 130 \quad$ Fax: $562-671-2799$

Date completed: $\quad 4 / 8 / 92$

C. 17 


\section{GENERAL OVERVEW OF BUILOING ENERGY STANDARDS}

1. General building standards exist at the following governmental levels:

National $\quad$ Regional

2. Proposed or existing ENERGY standards cover the following building sectors: Both Residential and Non-Residential

3. Status of Non-Residential Building Energy Standards at the:

b. Regional level:

- None

c. Local level:

- None

4. Single energy standard selected for further description:

Tite, Organization: "Energy Conservation Design Standard on Building Envelope and Air Conditioning for Tourist Hotels," The National Technology Supervision Bureaw and the Ministry of Construction $1992 / 93$

Year: 1993

Geographic Coverage: Nation

Abbreviated Title: NTSB-93

DESCRIPTION OF SPECIFIED ENERGY STANDARDS - NTSB-93

5. The standard defined in Question 4 applies to the following kinds of buildings:

a. Building types:

H - Hotels

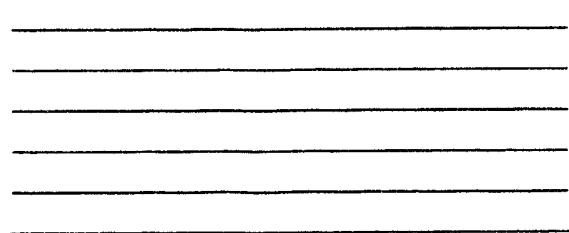

b. Building vintage:

New buildings

c. Other characteristics:

A - Air-Conditioned

6. Basic approach of the standard: Both prescriptive and performance

7. The following subjects are included in the energy standard:

a Whole building energy provisions:

E- Energy amount target

c. Lighting provisions:

- None

e. Other provisions: b. Building envelope provisions:

Roof

Wall system

Fenestration system

Infiltration

\section{d. Mechanical provisions:}

Air/Water distribution efficiency Load Calculations for equipment sizing Controls

Ventilation

Equipment efficiency

Yes: Thickness of insulation for pipe and duct. Thermostat settings. 


\section{STANDARDS DEVELOPNENT PROCESS - NTSB-93}

\section{Organteations imvolved in developing the standard:}

Government agency: The Bureau of Standards and Rating of the Construction Ministry

Academic institution: Institute of Air Conditioning

Academic institution: Beijing Institute of Architectural Design

\section{Decision Process: Consensus}

10. Information used in developing the standard:

a. PHYSICAL CHARACTERISTICS of existing buildings

Estimated using professional judgment

Gathered through audits and surveys

\section{c. WEATHER data}

Gathered through measurements

11. Standards from a different country used as source material:

USA: ASHRAE 90.1-1989
Comment Guanzhou Institute of Architectureal Design; Middle South-China Instititute of Architectural Design; East-China

\section{b. ENERGY USE of existing buildings:}

Gathered through audits and surveys

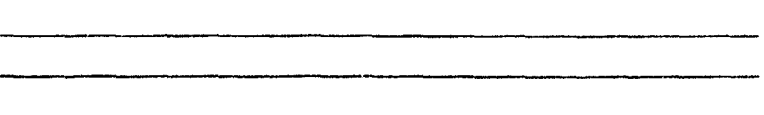

\section{d. Other information}

-None

12. COMPUTER programs used:

a. In developing the standard:

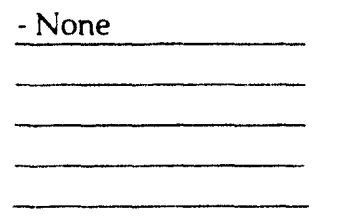

b. For complying with the standard:

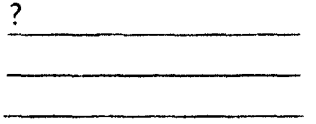

13. Standard is set at a level: Above current practice

14. Considerations influencing the inclusion or exclusion of measures in the standard:

E- Cost effectiveness

A - Availability of energy efficient products

C - Comfort

Comments:

15a. Standard scheduled for regular review and revision?

Yes: The standard will be approved by the Bureau of Standard and Rating of the Construction Ministry. I believe that it will be reviewed and revised after application of the Standard.

b. Does revision include procedures to MONITOR and EVALUATE earlier versions of the standard?

Yes 
16. Entities involved in IMPLEMENTNG energy standards:

- None: the standard is proposed

If an existing agency was made responsible for implementation, its former focus was on buildings, energy, or another area:

17. TRAINING \& EDUCATION provided for architects, engineers and other professionals:

Written guidelines to assist with compliance procedure

Example calculations

Compliance forms

Seminars, workshops, or conferences

18. Compliance mechenisms used at different stages in construction process:

a. PRIOR to construction:

Percent designs checked: :

Comment b. DURING construction:

Percent sites

Percent sites checked: -

Comment:

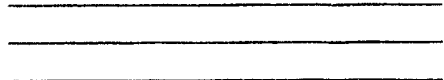

c. AFTER construction:

Percent buildings checked:

Comment

d. Other compliance procedures

e. Effectiveness of combined compliance mechanisms (scale of 1-5):

f. Explanation for effectiveness in part e: The Standard hasn't been approved.

19. Types of assessments or audits of energy standards' impact:

a. ENERGY SAVINGS POTENTIAL based on prototypical (not actual) buildings:

Completed: research report (in Chinese)

b. MEASUREMENTS OF ENERGY SAVINGS in actual buildings complying with standard:

None conducted

c. COST EFFECTIVENESS based on engineering economic CALCULATIONS:

None conducted

d. COST EFFECTIVENESS based on ACTUAL COSTS:

None conducted

e. Other Assessments: None conducted 


\section{FURTHER NIFORMATION ON ENERGY CONSERVATION - ChIna}

20. Efficiency testing facilties and procedures established:

Insulation

Air conditioners/chillers/other appliances

Thermal properties of materials

21. Other programs or policies developed to increase energy efficiency in buildings:

?

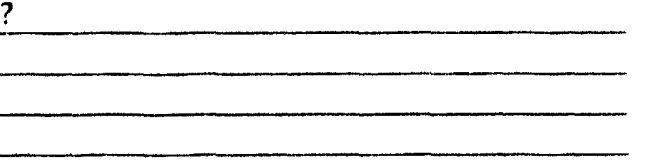

comment:

\section{Additional sources of information about energy efficiency for buildings in: China}

1.

2.

3.

22. Contact for written copy of energy standard specified in Question 4:

Name

Address:

Country:

Tel:

Fax:

Types of supporting information available:

"Item Explanation of the Standard."

Other energy standards for non-residential buildings:

Survey completed by: Lang Siw ei

Title: Director, Institute of Air Conditioning

China Academy of Building Research

P.O. Box 752

Beijing 100013

Country: PR China

Tel: $\quad 9-011-86-1-421-1133 \quad$ Fax: $9-011-86-1-421-3555$

Date completed: $\quad 7 / 22 / 92$ 


\section{GENERAL OVERVIEW OF BUILDING ENERGY STANDARDS}

1. Generd building standards exist at the following governmental levels:

National

2 Proposed or existing ENERGY standards cover the following building sectors: Both Residential and Non-Residential

3. Status of Non-Residential Building Energy Standards at the:

a National level:

Proposed

b. Regional level:

a. Local level

$\frac{\text { Mandatory }}{\text { Voluntary }}$

4. Single energy standard selected for further description:

Title, Organization: Proposed energy standard

Year: 199?

Geographic Coverage: Nation

Abbreviated Title: PES

\section{DESCRIPTION OF SPECIFIED ENERGY STANDARDS - PES}

5. The standard defined in Question 4 applies to the following kinds of buildings:

a. Building types:

$\mathrm{O}$ - Offices

H - Hotels

G - Government Facilities

C-Commercial/retail stores

S - Single-family residential

M - Multi-family residential b. Building vintage:

New buildings

C. Other characteristics:

P - Physical size $(10,000$ sq. ft)

A - Air-Conditioned

6. Basic approach of the standard: Both prescriptive and performance

7. The following subjects are included in the energy standard:

a. Whole building energy provisions:

- None

\section{c. Lighting provisions:}

Control requirements

Power density

Illumination requirements

\section{e. Other provisions:}

b. Building envelope provisions:

- None

d. Mechanical provisions:

Air/Water distribution efficiency

Load Calculations for equipment sizing

Controls

Ventilation

Equipment efficiency

Yes: thermostat settings 


\section{Organtzations involved in developing the standard:}

Government agency: Comicion Nacional de Energia

Industry group

Academic institution

Foreign development agency: World Bank

9. Decision Process: Consensus Comment:

10. Information used in developing the standard:

a. PHYSICAL CHARACTERISTICS of existing buildings

Gathered through audits and surveys

\section{c. WEATHER data}

Gathered through measurements

11. Standards from a different country used as source material:

USA: ASHRAE 90.1-89

Jamaica: EEBC-90

\section{b. ENERGY USE of existing buildings:}

Gathered through audits and surveys

\section{d. Other information}

-None

\section{COMPUTER programs used:}

a In developing the standard: DOE-2

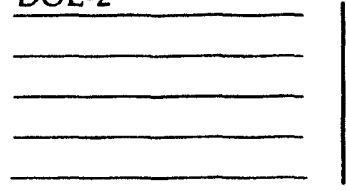

b. For complying with the standard: No

13. Standard is set at a level: Equal to current practice

14. Considerations influencing the inclusion or exclusion of measures in the standard:

E - Cost effectiveness

A - Availability of energy efficient products

S - Similarity/difference to local design

C-Comfort

15a. Standard scheduled for regular review and revision?

Yes

b. Does revision include procedures to MONTOR and EVALUATE earlier versions of the standard?

Yes 
16. Entities involved in MPLEMENTWG energy standards:

Existing agency: utilities

If an existing agency was made responsible for implementation, its former focus was on buildings, energy, or another area: Energy

17. TRAINING \& EDUCATION provided for architects, engineers and other professionals:

Written guidelines to assist with compliance procedure

Example calculations

Compliance forms

Seminars, workshops, or conferences

Information or resource center

18. Compliance mechanisms used at different stages in construction process:

a. PRIOR to construction:

Incentive

Percent designs checked:

Comment:

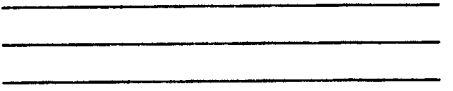

d. Other compliance procedures

e. Effectiveness of combined compliance mechanisms (scale of 1-5):

t. Explanation for effectiveness in part e:

19. Types of assessments or audits of energy standards' impact:

a. ENERGY SAVINGS POTENTLAL based on prototypical (not actual) buildings:

None conducted

b. MEASUREMENTS OF ENERGY SAVINGS in actual buildings complying with standard:

None conducted

c. COST EFFECTIVENESS based on engineering economic CALCULATIONS:

None conducted

d. COST EFFECTIVENESS based on ACTUAL COSTS:

None conducted

e. Other Assessments: None conducted c. AFTER construction:

Incentive

Percent buildings checked:

Comment: 
20. Eficiency teating facilities and procedures established:

Motors

Ballasts

21. Other programs or policies developed to increase energy efficiency in buildings:

- None

\section{Additional sources of information about energy efficiency for buildings in: Colombia}

1. World Bank preliminary report: Estudiode Eficiencia Energetica en Colombia (Phase 18z2, in Spanish)

2.

3.

22. Contact for written copy of energy standard specified in Question 4:

Neme:

Address:

Country:

Tel:

Fax

Comment

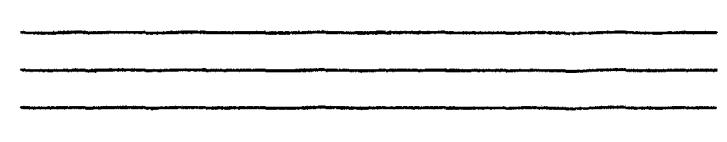

Types of supporting information available:

Other energy standards for non-residential buildings: 


\section{GENERAL OVERVEW OF BUILDING ENERGY STANDARDS}

1. General bulling standards exist at the following governmental levels:

National

2. Proposed or existing ENERGY standards cover the following building sectors: Both Residential and Non-Residential

3. Status of Non-Residential Building Energy Standards at the:
a Nationed lovel:
Mandatory
b. Regional level:
G. Local level:

- None

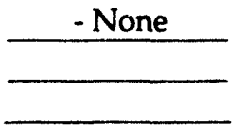

4. Single energy standard selected for further description:

Titie, Organization: CSN 730540 Thermo-technical properties of engineering structures and buildings. Nomenclature. Requirements and criteria. 1/1/79. Federal office for Standards and Measurement. Prague

Year: 1979

Ceographic Coverage: Nation

Abbreviated Title: $\quad$ CSN 730540

\section{DESCRIPTION OF SPECIFIED ENERGY STANDARDS - CSN 730540}

5. The standard defined in Question 4 applies to the following kinds of buildings:

a Building types:

O - Offices

H - Hotels

F - Restaurants

D - Hospitals

M-Multi-family residential

$X$ - Other: agricultural buildings b. Building vintage:

Both new and existing

c. Other characteristics:

$P$ - Physical size: volume

E-Amount of energy: dependent on size

6. Basic approach of the standard: Performance-based

7. The following subjects are included in the energy standard:

a. Whole bulding energy provisions:

E- Energy amount target

\section{c. Lighting provisions:}

- None

e. Other provisions: b. Building envelope provisions:

Roof

Wall system

Fenestration system

Infiltration

Other: floor

d. Mechenical provisions:

- None 


\section{STANDARDS DEVELOPMENT PROCESS - CSN 730540}

8. Organizations involved in developing the standard:

Government agency: Federal Office for Standards and Measurement, Prague

Academic institution: Technical University, Prague; Technical University, Bratislava

Government agency: Ministry of Building Trade

Other: design organzations

9. Decision Process: Consensus

Comment

10. Information used in developing the standand:

a. PHYSICAL CHARACTERISTICS of existing buildings

Estimated using professional judgment Gathered through audits and surveys

\section{c. WEATHER data}

Estimated using professional judgment Gathered through measurements

11. Standards from a different country used as source material:

Germany: DIN 4108 Wämeschutz im Hochban Austria: Onorm B 8110

\section{b. ENERGY USE of existing buildings:}

Estimated using professional judgment

Gathered through audits and surveys

\section{d. Other information}

-None
12. COMPUTER programs used:

a. In developing the standard:

- None

b. For complying with the standard:

13. Standard is set at a level: Above current practice

14. Considerations influencing the inclusion or exclusion of measures in the standard:

E - Cost effectiveness

Similarity/difference to local design

Comfort
Comments:

Cost effectiveness is dominant

\section{5a. Standard schectuled for regular review and revision?}

Yes: There are 3 proposals. Each is discussed by organizations that play important roles in developing standards.

b. Does revision include procedures to MONTOR and EVALUATE eartier versions of the standard?

$\mathrm{N}$ 


\section{CZECHOSLOVAKIA}

\section{MPLLENETATION AND COUPLIANCE - CSN 730540}

16. Entities involved in MPLEMENTNG energy standards:

Existing agency: Federal Office for Standards

\section{If an existing agency was made responsible for implementation, its former focus was on buildings, energy, or another area:}

Energy

17. TRANING \& EDUCATION provided for architects, engineers and other professionals:

Written guidelines to assist with compliance procedure

Example calculations

Seminars, workshops, or conferences

18. Compliance mechanisms used at different stages in construction process:

a. PRIOR to construction:

Certification/approval

Percent designs checked: 100

Comment:

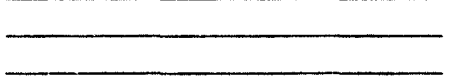

b. DURING construction:

Penalty

Percent sites checked: 50

comment

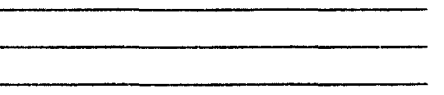

c. AFTER construction:

Certification/approval

Percent buildings checked: 90

Comment:

d. Other compliance procedures - None

e. Eflectivencis of combined compliance mechanisms (scale of 1-5): 5

f. Explanation for effectiveness in part e: Designers and realizers [builders] must cooperate.

19. Types of assessments or audits of energy standards' impact:

a. ENERGY SAVNGS POTENTIAL based on prototypical (not actual) buildings:

In progress

b. MEASUREMENTS OF ENERGY SAVNGS in actual buildings complying with standard:

Completed: Rehanek, J. "Improvement of Thermo-Technical Properties of Building Structures. SNTL Prague, In progress

c. COST EFFECTIVENESS based on engineering economic CALCULATIONS:

In progress

d. COST EFFECTIVENESS based ON ACTUAL COSTS:

In progress

e. Other Assessments: ? 


\section{FURTHER INFORMATION ON ENERGY CONSERVATION - CZEChoslovakia}

20. Efficiency testing facilities and procedures established:

Motors

Insulation

Air conditioners/chillers/other appliances

Fixtures

Thermal properties of materials

Other: fire protection of materials

21. Other programs or policies developed to increase energy efficiency in buildings:

?

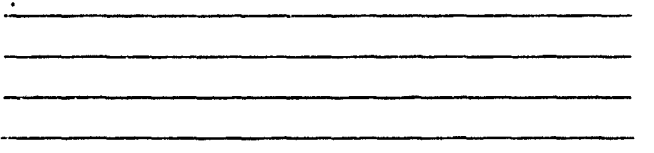

Comment

Additional sources of information about energy efficiency for buildings in: Czechoslovakia

1. Joumal of Federal Office for Standards_and Measurement (in Czech, Megezin CSN)

2. Halabyja, M et al: "Building Thermal Technics, Acoustics, and Daylighting," Alfa Bratislava, 1985 (In Slovak, "Stavebna Tepelna Technika. Akustiva a Osvetlenie.")

3. Rehanek, J 1982 Thermo-Technical Standards (In Czech, "Tepelne Technicke Normy") Funm Prague.

22. Cortact for written copy of energy standard specified in Question 4:

Nane

Address: Federal Office for Standards and Measurement

Distribution of CSN

Na Príkope 17

11347 Prague

Country: Czechoslovakia

Tel: $\quad 2352152$

Fax:

Types of supporting information available:

Rehanek, J. 1982. Thermo-Technical Standards, (In Czech, "Tepelne Technicke Normy") Funm Prague.

Other energy standards for non-residential buildings:

CSN 73 0560: Thermo-Technical Properties of Engineering Structures. Industrial Plants. (FESM)

Survey completed by: Ivan Chmurny

Title: Slovak Technical University

Department of Building Physics

Radlinského 11

81368 Bratislava Country: Czechoslovakia

Tel: $427-57448 \quad$ Fax: $427-499027$

Date completed: $\quad 6 / 30 / 92$ 


\section{GENERAL OVEAVEW OF BUILDING ENERGY STANDARDS}

1. General building standards exist at the following govemmental levels:

National

2. Proposed or existing ENERGY standards cover the following building sectors:

Both Residential and Non-Residential

3. Status of Non-Residential Building Energy Standards at the:
a National level:
Mandatory
b. Recional level:
- None
c. Local level: __ - None

4. Single energy standard selected for further description:

Title, Organization: Building Regulations, Danish Ministry of Building and Housing (Effective April 1.:-

i3)

Year: 1982

Geographic Coverage: Nation

Abbreviated Title: $\quad$ BR-DMBH, 1982

\section{DESCRIPTION OF SPECIFIED ENERGY STANDARDS - BR-DMBH, 1982}

5. The standard defined in Question 4 applies to the following kinds of buildings:

a. Building types:

A - All Buildings

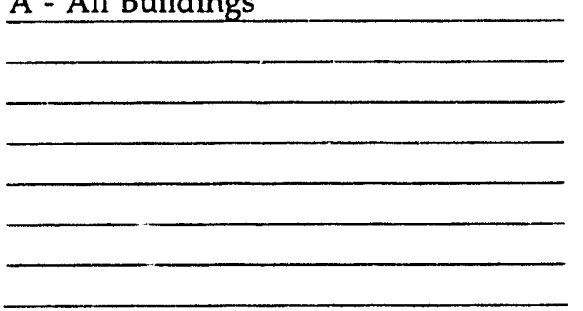

b. Building vintage:

New buildings

c. Other characteristics:

P - Physical size

6. Basic approach of the standard: Both prescriptive and performance

7. The following subjects are included in the energy standard:

a. Whole building energy provisions:

- None

c. Lighting provisions:

- None

e. Other provisions:

-None b. Building envelope provisions:

Roof

Wall system

Fenestration system

Infiltration

d. Mechanical provisions:

Controls

Ventilation

Other: Efficiency requirements for central heating 
STANDARDS DEVELOPMENT PROCESS - BR-DMBH, 1982

8. Organizations involved in developing the standard:

Government agency: Building Agency

Government agency: Energy Agency

Research group: National Building Research Institute

9. Decision Process: Consensus

Comment

10. Information used in developing the standard:

a. PHYSICAL CHARACTERISTICS of existing buildings

\section{c. WEATHER data}

11. Standards from a different country used as source material:

- None b. ENERGY USE of existing buildings:

d. Other information

Building Regulations concern only new buildings

12. COMPUTER programs used:

a In developing the standard: TSBI

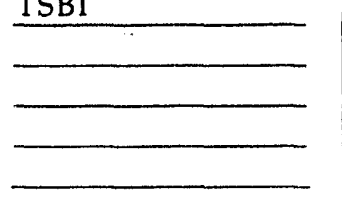

b. For complying with the standard: No

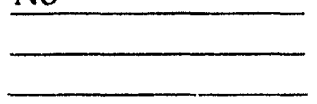

13. Standard is set at a level: Above current practice

\section{Considerations influencing the inclusion or exclusion of measures in the standard:}

E - Cost effectiveness

Availability of energy efficient products

Comfort
Comments:

15a. Standard scheduled for regular review and revision?

Yes: the 1983 regulations are at the moment under revision.

b. Does revision include procedures to MONTOR and EVALUATE earlier versions of the standard?

$\mathrm{No}$

$$
C \cdot 31
$$




\section{IMPLEMENTATION AND COMPLANCE - BR-DMBH, 1982}

16. Entities involved in IMPLEMENTING energy standards:

Existing agency: Building Agency (administered by municipalities)

If an existing agency was made responsible for implementation, its former focus was on buildings, energy, or another area:

Buildings

17. TRAINING \& EDUCATION provided for architects, engineers and other professionals:

Written guidelines to assist with compliance procedure

18. Compliance mechanisms used at different stages in construction process:

a. PRIOR to construction:

Certification/approval

Percent designs checked: ?

Comment:

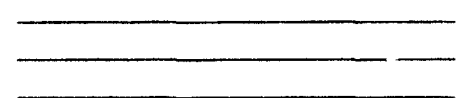

b. DURING construction:

Certification/approval

Percent sites checked: ?

comment:

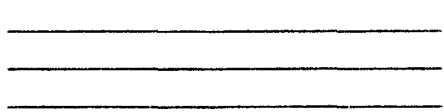

c. AFTER construction:

Certification/approval

Percent buildings checked: ?

Comment:

d. Other compliance procedures

e. Eflectiveness of combined compliance mechanisms (scale of 1-5): 4

f. Explanation for effectiveness in part e: Tradition and extended reliability

19. Types of assessments or audits of energy standards' impact:

a. ENERGY SAVINGS POTENTIAL based on prototypical (not actual) buildings:

Completed

b. MEASUREMENTS OF ENERGY SAVINGS in actual buildings complying with standard:

Completed

c. COST EFFECTIVENESS based on engineering economic CALCULATIONS:

Completed

d. COST EFFECTIVENESS based on ACTUAL COSTS:

None conducted

e. Other Assessments: - 


\section{FURTHER INFORMATION ON ENERGY CONSERVATION - DEnmark}

20. Efficiency testing facilities and procedures established:

Insulation

Thermal properties of materials

Other: boilers (oil and gas)

21. Other programs or policies developed to increase energy efficiency in buildings:

Information programs

Audits (free or subsidized)

Rebates
Comment Energy efficiency has been under the Ministry of Housing and Building up to 1989, whereafter the Ministry of Energy took over (i.e. Energy Agency).

Additional sources of information about energy efficiency for buildings in: Denmark

1. "Denmark Uses Energy Befter," National Building Agency.

2. "Energy Efficiency in New Buildings." Report conducted by COWIconsult and SBL in Denmark at the request of the Commission of the European Communities, December 1991.

3.

22. Contact for written copy of energy standard specified in Question 4:

Name

Address:

Country:

Tel:

Fax:

Types of supporting information available:

Other energy standards for non-residential buildings:

"Control and Maintenance of Larger Oil- and Gas-fired Heating INstallations and Heating

Survey completed by: Jesper Lorentzen

Title: Engineering, Head of Section

Danish Energy Agency

Landemaerket 11, DK-1119

Copenhagen $\mathrm{K}$

Country: Denmark

Tel: $\quad+4533926700$

Fax: +4533114743

Date completed: $\quad 4 / 2 / 92$ 


\section{GENERAL OVERVIEW OF BUILDING ENERGY STANDARDS}

1. General building standards exist at the following governmental levels:

National

2. Proposed or existing ENERGY standards cover the following building sectors: Both Residential and Non-Residential

3. Status of Non-Residential Building Energy Standards at the:

a. National level:

b. Regional level: Mandatory

a. Local level:

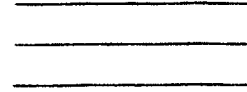

4. Single energy standard selected for further description:

Title, Organization: The Building Regulations, Part I. Department of the Environment (England and Wales)

Year: 1990

$$
\text { Geographic Coverage: Nation }
$$

Abbreviated Title: BR-ADL1, 1990

\section{DESCRIPTION OF SPECIFIED ENERGY STANDARDS - BR-ADL1, 1990}

5. The standard defined in Question 4 applies to the following kinds of buildings:

a. Building types:

A - All Buildings

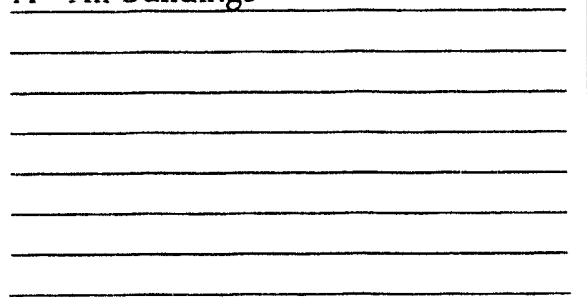

b. Building vintage:

Both new and existing

c. Other characteristics:

Other: exception made for unheated buildings

6. Basic approach of the standard: Both prescriptive and performance

7. The following subjects are included in the energy standard:

a. Whole bulding energ; provisions:

E- Energy amount target

Other: target for space heating for dwellings

c. Lighting provisions:

- None

e. Other provisions:

- None b. Building envelope provisions:

Roof

Wall system

Fenestration system

Other: Floor insulation

\section{d. Mechanical provisions:}

Controls

Ventilation

Other: insulation of ducts, pipework and hot water storage 
STANDARDS DEVELOPMENT PROCESS - BR-ADL1, 1990

ENGLAND \& WALES

8. Organizations involved in developing the standard:

Government agency: British Research Establishment

Industry group

Academic institution

Research group

Other: Public consultation

9. Decision Process: Consensus

Comment: Lead taken by central government. Result becomes mandatory.

10. Information used in developing the standard:

a. PHYSICAL CHARACTERISTICS of existing buildings

Estimated using professional judgment

Gathered through audits and surveys

Already available prior to standard

\section{c. WEATHER data}

Already available prior to standard

11. Standards from a different country used as source material:

- None b. ENERGY USE of existing buildings:

Estimated using professional judgment

Already available prior to standard

\section{d. Other information}

Yes: cost of improvements to enable cost-effectiveness calculations to be made.

12. COMPUTER programs used:

a. In developing the standard:

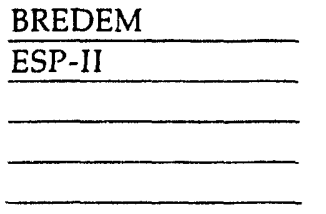

b. For complying with the standard: BREDEM

13. Standard is set at a level: Above current practice

14. Considerations influencing the inclusion or exclusion of measures in the standard:

E- Cost effectiveness

Availability of energy efficient products

Comfort

Other: Capability of construction industry to standard without undue techinical risks.

\section{5a. Standard scheduled for regular review and revision?}

Yes: 1) Consultation with Building Regulation Advisory Committee, experts; 2) Public consultation; 3)

Parliamentary approval.

b. Does revision include procedures to MONTOR and EVALUATE earlier versions of the standard?

Yes: Through consultation process, with strong emphasis on technical risk. 


\section{ENGLAND \& WALES}

\section{IMPLEMENTATION AND COMPLIANCE - BR-ADL1, 1990}

16. Entities involved in IMPLEMENTING energy standards:

Existing agency: Department of the Environment, enforced at local level

If an existing agency was made responsible for implementation, its former focus was on buildings, energy, or another area:

Other: Environment, planning, land use

\section{TRAINING \& EDUCATION provided for architects, engineers and other professionals:}

Written guidelines to assist with compliance procedure

Example calculations

Seminars, workshops, or conferences

Information or resource center

18. Compliance mechanisms used at different stages in construction process:

a. PRIOR to construction:

Certification/approval

Percent designs checked: 100

Comment:

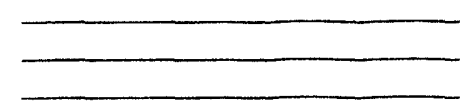

b. DURING construction:

Certification/approval

Percent sites checked: ? Comment:

Random inspection for energy measures $(100 \%$ for other measures, e.g foundations) c. AFTER construction:

No mechanism

Percent buildings checked: low Comment:

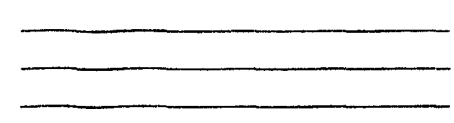

d. Other compliance procedures

e. Effectiveness of combined compliance mechanisms (scale of 1-5): 4

t. Explanation for effectiveness in part e: Accepted as part of standard building control system.

19. Types of assessments or audits of energy standards' impact:

a. ENERGY SAVINGS POTENTIAL based on prototypical (not actual) buildings:

In progress

b. MEASUREMENTS OF ENERGY SAVINGS in actual buildings complying with standard:

In progress

c. COST EFFECTIVENESS based on engineering economic CALCULATIONS:

Completed

d. COST EFFECTIVENESS based ON ACTUAL COSTS:

None conducted

e. Other Assessments: In progress: survey of methods to achieve specified levels. 


\section{FURTHER INFORMATION ON ENERGY CONSERVATION - England \& Wales}

20. Efficiency testing facilities and procedures established:

Motors

Insulation

Air conditioners/chillers/other appliances

Ballasts

Thermal properties of materials

Other: controls

21. Other programs or policies developed to increase energy efficiency in buildings:

Information programs

Government energy policy

Comment:

$\longrightarrow$

Additional sources of information about energy efficiency for buildings in: England \& Wales

1. The Building Regulations, 1985 (1990 Edition). Part I- The Conservation of Euel and Power, HMSO, London.

2. A.B. Birtleg, "Achieving Energy Efficiency in Buildings," Proceedings of the 14th Annual International Conference for Energy Economics. Honolulu, 1991

3.

22. Contact for written copy of energy standard specified in Question 4:

Name

Address:

BRE Bookshop

Bucknalls Lane, Garston

Watford WD2 7JR England

Country: United Kingdom

Tel: $\quad$ 44-923-664 444

Fax:

Types of supporting information available:

Other energy standards for non-residential buildings:

Sunvey completed by: George Henderson

Title: Energy Economics and Statistics Section

British Research Establishment

Garston

Watford WD2 7JR Country: England

Tel: $\quad 44923664517$

Fax: 44923664097

Date completed: $\quad 3 / 6 / 92$ 


\section{CENER W OVEAVEW OF BUILDING ENERCY STANDARDS}

1. General building standards exist at the following governmental lovels:

National

Local

2. Proposed or existing ENERGY standards cover the following building sectors: Both Residential and Non-Residential

3. Status of Non-Residential Building Energy Standards at the:

a National level:

Mandatory

b. Regional level:

- None

c. Local level: - None

4. Single energy standard selected for further description:

Titte, Organization: Regulmentation Thermique Tertiaire. Energy Efficiency Standards in Non-Residential Buildings. Ministry of Industry and Buildings, 1988.

Year: 1988

Ceographic Coverage: Nation

Abbreviated Title: CSTB- 88

\section{DESCRIPTION OF SPECIFIED ENERGY STANDARDS - CSTB-88}

5. The standard defined in Question 4 applies to the following kinds of buildings:

a. Building types:

O- Offices

H - Hotels

G - Government Facilities

F - Restaurants

D - Hospitals

C - Commercial/retail stores

E - Educational facilities (schools)

I - Industrial Buildings b. Building vintage:

New buildings

C. Other characteristics:

F - Type of fuel: more restrictive for electric heating systems

6. Basic approach of the standard: Both. prescriptive and performance

7. The following subjects are included in the energy standard:

a. Whole building energy provisions:

- None

c. Lighting provisions:

- None

e. Other provisions:

Yes: Thermostat settings. The type of use of the building is taken into account to specify standard levels depending on how much time it is used: continuous use or discontinuous. b. Building envelope provisions:

Roof

Wall system

Fenestration system

Infiltration

Other: floor insulation, solar gains

d. Mechanical provisions:

Controls: descriptive on equipment Ventilation: descriptive on equipment

C. 38 


\section{Organtations involved in developing the standerd:}

Government agency: Minstry of Buildings

Government agency: Ministry of Industry

Research group: CSTB

Government agency: Ademe

9. Dectsion Process: Consensus

Comment Energy producers, professional associations

10. Information used in developing the standard:

a. PHYSICAL CHARACTERISTICS of existing buildings

Gathered through audits and surveys Already available prior to standard

\section{c. WEATHER data}

Already available prior to standard

11. Standards from a different country used as source material:

- None

\section{b. ENERGY USE of existing buildings:}

Estimated using professional judgment

Computer simulations used for estimates Gathered through audits and surveys

\section{d. Other information}

-None

12. COMPUTER programs used:

a In developing the standard:

Uncertain

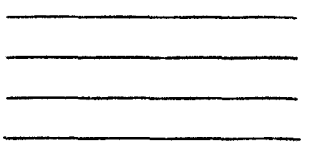

b. For complying with the standard:

Uncertain

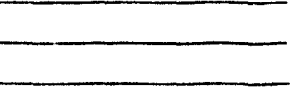

13. Standard is set at a level: Lower than current practice

14. Considerations influencing the inclusion or exclusion of measures in the standard:

E - Cost effectiveness

Comments:

A - Availability of energy efficient products

C-Comfort

\section{5a. Standard scheduled for regular review and revision?}

Yes: through steps of regulation that induce an increasing level of standards: 1976, 1988, 1995 (?)

b. Does revision include procedures to MONTOR and EVALUATE earlier versions of the standard?

No: yet some surveys have been conducted to check the level of compliance to existing building energy standards. 
16. Entties involved in MPLEMENTING energy standards:

Existing agency: CSTB

If an existing agency was made responsible for implementation, its former focus was on bulldings, energy, or another area:

Buildings

17. TRANING \& EDUCATION provided for architects, engineers and other professionals:

Written guidelines to assist with compliance procedure

Example calculations

Compliance forms

Seminars, workshops, or conferences

18. Compliance mechanisms used at different stages in construction process:

a. PRIOR to construction:

Certification/approval

Percent designs checked: ?

comment:

technical_certification on materials and equipment b. DURWG construction:

?

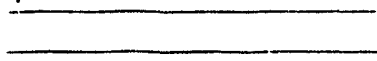

Percent sites checked: ? Comment

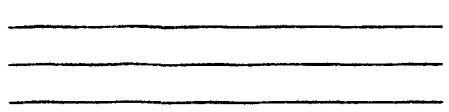

c. AFTER construction:

?

Percent buildings checked: ?

Comment:

d. Other compliance procedures - None

e. Effectiveness of combined compliance mechanisms (scale of 1-5): ?

f. Explanation for effectiveness in part e:

19. Types of assessments or audits of energy standards' impact:

a. ENERGY SAVINGS POTENTIAL based on prototypical (not actual) buildings:

Completed: goal: $-25 \%$ heating consumption; economy : 50,000TOE/year

b. MEASUREMENTS OF ENERGY SAVNGS in actual buildings complying with standard:

?

c. COST EFFECTIVENESS based on engineering economic CALCULATIONS:

?

d. COST EFFECTIVENESS based on ACTUAL COSTS:

?

e. Other Assessments: ? 


\section{FURTHER WFORUATION ON ENERGY CONSERVATION - FRance}

20. Efficiency testing facilities and procedures established:

Motors

Insulation

Air conditioners/chillers/other appliances

Ballasts

Fixtures

Thermal properties of materials

21. Other programs or policies developed to increase energy efficiency in buildings:

Audits (tree or subsidized)

Information programs

Rebates

Additional sources of information about energy efficiency for buildings in: France

1.

2.

3.

22. Contact for written copy of energy standard specified in Question 4:

Name

Address:

Country:

Tel:

Fax:

Types of supporting information available:

Other energy standards for non-residential buildings:

Survey completed by:

Robert Angioletti

Title: Environment and Energy Management Agency (Ademe)

500 , route des Lucioles

Sophia-Antipolis

06565 VALBONNE

Tel: $\quad 3393957931$

CEDEX Country: France

Fax: 3393653196

Date completed: $\quad 8 / 3 / 92$ 


\section{GENERAL OVEAVEW OF BULDING ENERGY STANDARDS}

1. General building standards exist at the following governmental levels:

National

2. Proposed or existing ENERGY standards cover the following building sectors: Non-Residential Only

3. Status of Non-Residential Building Energy Standards at the:
a National level:
Proposed
b. Regional level:
Proposed
a. Local level: _ Proposed

4. Single energy standard selected for further description:

Titte, Organization: Code of Practice on Calculation of Overall Thermal Transfer Value to Building Envelope, Hong Kang Government (Draft, August 1991)

Year: 1991 Geographic Coverage: C__ Cities _ Abbreviated Title: OTTV-HKG, 1991

\section{DESCAIPTION OF SPECIFIED ENERGY STANDARDS - OTTV-HKG, 1991}

5. The standard defined in Question 4 applies to the following kinds of buildings:

a. Building types:

Offices

Hotels



b. Building vintage:

New buildings

c. Other characteristics:

\section{A - Air-Conditioned}

$\longrightarrow$

6. Basic approach of the standard: Performance-based

7. The following subjects are included in the energy standard:

a Whole buiding energy provisions:

$?$

c. Lighting provisions:

- None

e. Other provisions: b. Building envelope provisions:

Roof

Wall system

Fenestration system

\section{d. Mectanical provisions:}

- None 


\section{STANDARDS DEVELOPMENT PROCESS - OTTV-HKG, 1991}

\section{Organizations involved in developing the standard:}

Government agency: Hong Kong Government, Building Ordinance Office

Research group: J. Roger Preston \& Partners, Consulting Engineers

Research group: Charles Eley and Associates

9. Decision Process: Consensus

Comment Hong Kong Governmentand / Roger Preston \& Partmers

10. Information used in developing the standard:

a. PHYSICAL CHARACTERISTICS of existing buildings

Gathered through audits and surveys

\section{c. WEATHER data}

Already available prior to standard

11. Standards from a different country used as source material:

UK

USA

Australia \& NZ

ASEAN

Japan

12. COMPUTER programs used:

a In developing the standard: DOE-2-1D

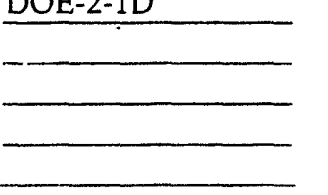

b. For complying with the standard:

\section{d. Other information}

-None

13. Standard is set at a level: Above current practice

14. Considerations influencing the inclusion or exclusion of measures in the standard:

E-Cost effectiveness

Availability of energy efficient products

Similarity/difference to local design
Comments:

\section{b. ENERGY USE of existing buildings:}

Computer simulations used for estimates Gathered through audits and surveys

15a. Standard scheduled for regular review and revision?

No

b. Does revision include procedures to MONTOR and EVALUATE earlier versions of the standard?

Unsure 


\section{HONG KONG}

\section{IMPLEMENTATION AND COMPLIANCE - OTTV-HKG, 1991}

16. Entities invotved in IMPLEMENTNG energy standards:

Existing agency: The Building Ordinance Office

If an existing agency was made responsible for implementation, its former focus was on buildings, energy, or another area:

Buildings

17. TRAINING \& EDUCATION provided for architects, engineers and other professionals:

Written guidelines to assist with compliance procedure

Example calculations

Compliance forms

18. Compliance mechanisms used at different stages in construction process:

a. PRIOR to construction:

Certification/approval

Percent designs checked: 100

Comment:

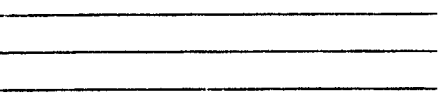

b. DURING construction:

No mechanism

Percent sites checked:

Comment

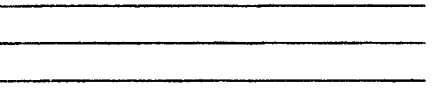

c. AFTER construction:

No mechanism

Percent buildings checked:

Comment.

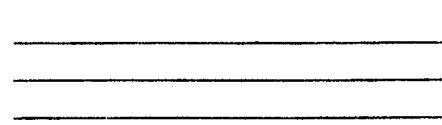

d. Other compliance procedures - None

e. Effectiveness of combined compliance mechanisms (scale of 1-5): 5

f. Explanation for effectiveness in part e: Because the professionals are made to be responsible and if deviations are discovered will be penalized.

19. Types of assessments or audits of energy standards' impact:

a. ENERGY SAVINGS POTENTIAL based on prototypical (not actual) buildings:

Completed

b. MEASUREMENTS OF ENERGY SAVINGS in actual buildings complying with standard:

None conducted

c. COST EFFECTIVENESS based on engineering economic CALCULATIONS:

None conducted

d. COST EFFECTIVENESS based on ACTUAL COSTS:

None conducted

e. Other Assessments: - None 


\section{FURTHER INFORMATION ON ENERGY CONSERVATION - HONg KONg}

\section{Efficiency testing facilities and procedures established:}

- None

\section{Other programs or policies developed to increase energy efficiency in buildings:}

-None

Comment

Additional sources of information about energy efficiency for buildings in: Hong Kong

1.

2.

3.

22. Contact for written copy of energy standard specified in Question 4:

Name Peter Osburne

Address: Building Ordinance Office

Buildings and Lands Department

Murray Building, Garden Road

Country: Hong Kong

Tel: $\quad 8528482830$

Fax:

Types of supporting information available:

-None

Other energy standards for non-residential buildings:

- None

$\begin{aligned} \text { Survey completed by: } & \text { K. C. Chan } \\ \text { Title: } & \text { Partner } \\ & \text { J. Roger Preston \& Partners } \\ & \text { Level } 3 \text { Maxi Mall, City Gardens } \\ & 233 \text { Electric Road }\end{aligned}$

Tel: $\quad 852-887-3321$

Fax: $852-887-8897$

Date completed: $\quad 3 / 26 / 92$ 


\section{GENERAL OVERVEW OF BUILDING ENERGY STANDARDS}

1. General building standards exist at the following governmental levels:

National

Regional

Local

2. Proposed or existing ENERGY standards cover the following building sectors: Non-Residential Only

3. Status of Non-Residential Building Energy Standards at the:
a National level:

Voluntary
b. Regional level:

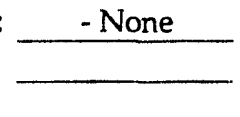
a. Local level: - None

4. Single energy standard selected for further description:

Title, Organization: Direktorat Tata_Angunan-DITABA (Directorate of Building)

Year: ?

Geographic Coverage: _. Nation _ Abbreviated Title: DITABA

\section{DESCRIPTION OF SPECIFIED ENERGY STANDARDS - DITABA}

5. The standard defined in Question 4 applies to the following kinds of buildings:

\section{a. Building types:}

O- Offices

H - Hotels

G-Government Facilities

D. Hospitals

M - Multi-family residential

I - Industrial Buildings b. Building vintage:

New buildings

c. Other characteristics:

A - Air-Conditioned

6. Basic approach of the standard: Both prescriptive and performance

7. The following subjects are included in the energy standard:

a. Whole building energy provisions:

E- Energy amount target

P- Peak electricity demand

C- Energy cost target

c. Lighting provisions:

Control requirements

Power density

Illumination requirements

Other: recommendation to use daylight

e. Other provisions: b. Building envelope provisions:

Roof

Wall system

Fenestration system

Infiltration

d. Mechanical provisions:

Air/Water distribution efficiency

Load Calculations for equipment sizing

Controls

Ventilation

Equipment efficiency

-None 


\section{STANDARDS DEVELOPMENT PROCESS - DITABA}

\section{Organizations involved in developing the standard:}

Government agency: Directorate of Building, Department of Public Works

Academic institution: Bandung Institute of Technology

Research group: Indonesia Institute of Science

Government agency: Building Research Center, Department of Public Works

Foreign development agency: ASEAN-US Energy project, Energy Conservation in Buildings

9. Decision Process: Consensus Comment

10. Information used in developing the standard:

a. PHYSICAL CHARACTERISTICS of existing buildings

Estimated using professional judgment Gathered through audits and surveys

\section{c. WEATHER data}

Gathered through measurements Already available prior to standard:

11. Standards from a different country used as source material: Singapore: Energy Conservation Handbook

\section{b. ENERGY USE of existing buildings:}

Estimated using professional judgment Computer simulations used for estimates Gathered through audits and surveys

\section{d. Other information}

Data on local materials, equipment, and installation commonly used.
12. COMPUTER programs used:

a In developing the standard:

DOE-2

$\overline{\mathrm{ASEAM}}$

b. For complying with the standard: Yes

Yes

13. Standard is set at a level: Above current practice

14. Considerations influencing the inclusion or exclusion of measures in the standard:

E - Cost effectiveness

Availability of energy efficient products

Similarity/difference to local design

Comfort

\section{Comments:}

Local design practice and local materials as well as. local availability of equipment and products will give great influence on the applicability of the standard.

15a. Standard scheduled for regular review and revision?

Yes: scheduled for review after several years in use as a guideline.

b. Does revision include procedures to MONTOR and EVALUATE earlier versions of the standard?

No 


\section{INDONESIA}

\section{IMPLEMENTATION AND COMPLIANCE - DITABA}

16. Entities involved in IMPLEMENTING energy standards:

Existing agency: Directorate of Buildings

If an existing agency was made responsible for implementation, its former tscus was on buildings, energy, or another area:

Buildings

17. TRAINING \& EDUCATION provided for architects, engineers and other professionals:

Written guidelines to assist with compliance procedure

Example calculations

Seminars, workshops, or conferences

Information or resource center

18. Compliance mechanisms used at different stages in construction process:

a. PRIOR to construction:

Certification/approval

Percent designs checked: ?

Comment

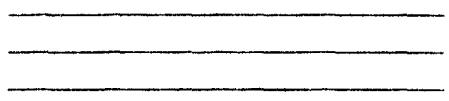

b. DURING construction:

Percent sites checked: ?

Percent sites checked: ? Comment

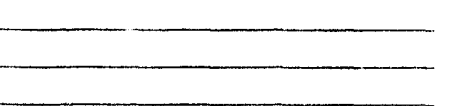

c. AFTER construction:

Percent buildings checked: ? Comment:

\section{d. Other compliance procedures - None}

e. Effectiveness of combined compliance mechanisms (scale of 1-5):

f. Explanation for effectiveness in part e: No evaluation has been done.

19. Types of assessments or audits of energy standards' impact:

a. ENERGY SAVINGS POTENTIAL based on prototypical (not actual) buildings:

Planned

b. MEASUREMENTS OF ENERGY SAVINGS in actual buildings complying with standard: In progress

c. COST EFFECTIVENESS based on engineering economic CALCULATIONS:

None conducted

d. COST EFFECTIVENESS based on ACTUAL COSTS:

None conducted

e. Other Assessments: - None 


\section{Efficiency testing facilities and procedures established:}

\section{Motors}

Insulation

Fixtures

Thermal properties of materials

\section{Other programs or policies developed to increase energy efficiency in buildings:}

Information programs

Audits (free or subsidized)
Comment Energy awareness campaigns for government efficials; Energy conservation in buildings seminars.

Additional sources of information about energy efficiency for buildings in: Indonesia

1. Seminar Proceeding:Seminar Kebijaksanaan Konservasi Energy Dalam Bangunan Gedung (Seminar on Policy on Energy Conservation in Buildings). Dept. of Public Works, 1989

2. "Penjusunan Pedoman Penggunaan Bahan Bangunan Gedung Negara Dalam Kaitannya Denga N Konservatsi Energi."

3. (translation of above) Guideline for the Use of Building Materials for Government Buildings in Relation to Energy Conservation.

22. Contacl for written copy of energy standard specified in Question 4:

Name Ir. Noraya

Address: DITABA, Public Works Department

Kra nat Raya 63

Jakarta

Country: Indonesia

Tel: $\quad 6221346939$

Fax:

Types of supporting information available:

Building Standard, Daylighting and Artificial_Lighting_Standards (Contact Ir. Soeprapto; Puslitbang Pemukiman, Public Works Dept, Cilenyi, Bandung, Indonesia)

Other energy standards for non-residential buildings:

General Policy on Energy; Guide on Energy Conservation Practice and Monitoring

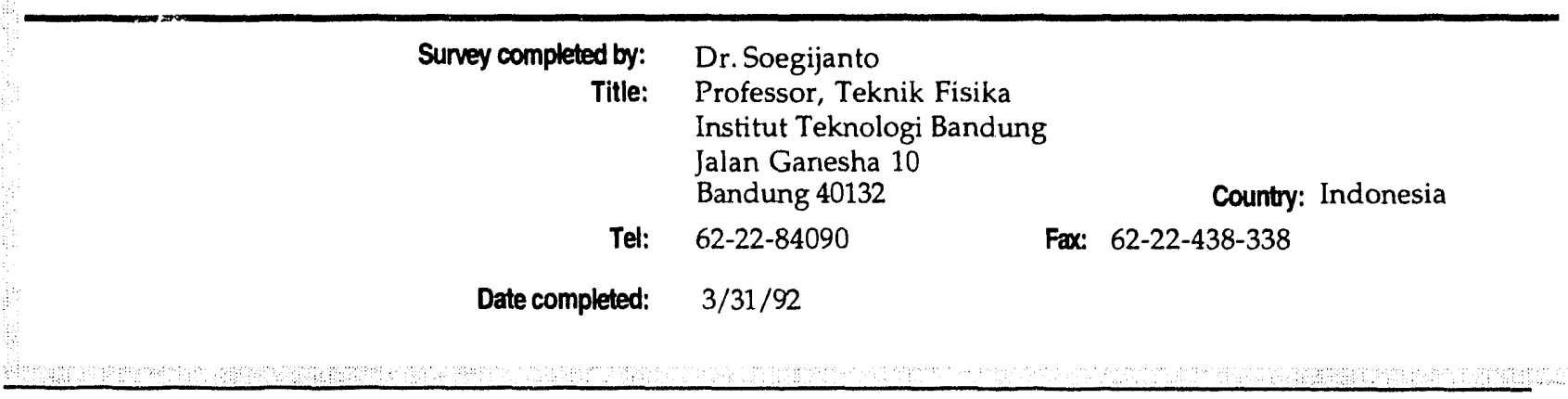




\section{ISRAEL}

\section{GENERAL OVERVIEW OF BUILDING ENERGY STANDARDS}

1. General building standards exist at the following governmental levels:

National

2. Proposed or existing ENERGY standards cover the following building sectors: Residential Only

3. Status of Non-Residential Building Energy Standards at the:

a National level: Mandatory (R)

b. Regional level:

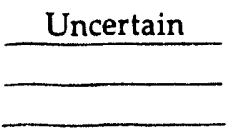

c. Local level: Uncertain

4. Single energy standard selected for further description:

Title, Organization: "Thermal_Insulation of Residential Buildings," the Standard Insitution of Israel

Year: 1989

Geographic Coverage: Nation

Abbreviated Title: TIRB-SII, 1989

\section{DESORIPTION OF SPECIFED ENERCY ST ANDARDS - TIRB SII, 1989}

5. The standard defined in Question 4 applies to the following kinds of buildings:

a. Building types:

S - Single-family residential

M - Multi-family residential

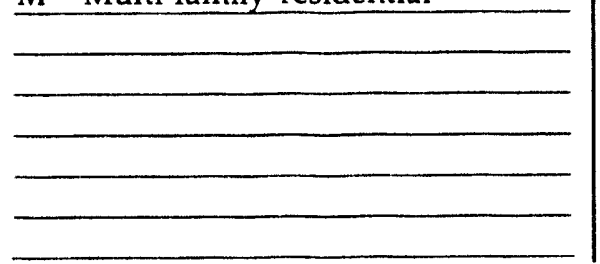

b. Building vintage:

New buildings

C. Other characteristics:

- None

6. Basic approach of the standard: Performance-based

7. The following subjects are included in the energy standard:

a. Whole building energy provisions:

- None

c. Lighting provisions:

- None

e. Other provisions:

\section{b. Building envelope provisions:}

Roof

Wall system

Fenestration system

Infiltration

d. Mechanical provisions:

- None 


\section{Organizations involved in developing the standard:}

Government agency: Governmental Building Office

Academic institution: Technion, Technical Institute for Building Research

Academic institution: Ben Gurion University

\section{Decision Process: Consensus}

Comment:

10. Information used in developing the standard:

a. PHYSICAL CHARACTERISTICS of existing buildings

Estimated using professional judgment Gathered through audits and surveys

\section{c. WEATHER data}

Already available prior to standard

11. Standards from a different country used as source material:

Germany: DIN Standards

\section{b. ENERGY USE of existing buildings:}

Gathered through audits and surveys

\section{d. Other information}

-None

12. COMPUTER programs used:

a In developing the standard:

- None

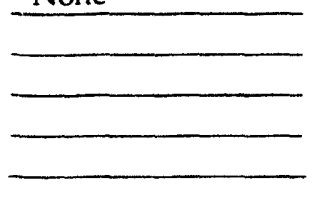

b. For complying with the standard:

Uncertain

13. Standard is set at a level: Lower than current practice

\section{Considerations influencing the inclusion or exclusion of measures in the standard:}

\section{E - Cost effectiveness}

\section{Comments:}

\section{5a. Standard scheduled for regular review and revision?}

Yes: The standard has been amended almost every year.

b. Does revision include procedures to MONTOR and EVALUATE earlier versions of the standard?

Yes 
16. Entities involved in MPLEMENTING energy standards:

Existing agency: municipal authorities

If an existing agency was made responsible for implementation, its former focus was on bulldings, energy, or another area: Buildings

17. TRAINING \& EDUCATION provided for architects, engineers and other professionals:

Written guidelines to assist with compliance procedure

Example calculations

Compliance forms

Seminars, workshops, or conferences

Information or resource center

18. Compliance mechanisms used at different stages in construction process:

a. PRIOR to construction:

Certification/approval

Percent designs checked: -

Comment:

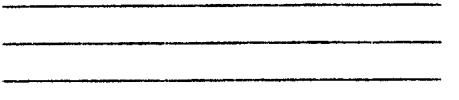

b. DURNG construction:

No mechanism

Percent sites checked: -

Comment:

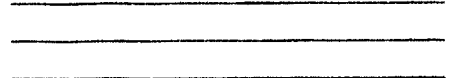

c. AFTER construction:

Certification/approval

Percent buidings checked: Comment:

Inspection by consumers.

d. Other compliance procedures

e. Effectiveness of combined compliance mechanisms (scale of 1-5): 4

f. Explanation for effectiveness in part e:

19. Types of assessments or audits of energy standards' impact:

a. ENERGY SAVINGS POTENTIAL based on prototypical (not actual) buildings:

b. MEASUREMENTS OF ENERGY SAVINGS in actual buildings complying with standard:

c. COST EFFECTIVENESS based on engineering economic CALCULATIONS:

Planned

d. COST EFFECTIVENESS based ON ACTUAL COSTS:

Planned

e. Other Assessments: 


\section{FURTHER INFORMATION ON ENERGY CONSERVATION - Israel}

20. Efficiency testing facilities and procedures established:

Insulation

Air conditioners/chillers/other appliances

Thermal properties of materials

21. Other programs or policies developed to increase energy efficiency in buildings:

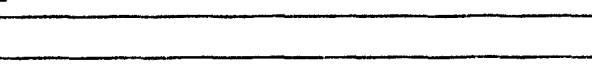

Commente

Additional sources of information about energy efficiency for buildings in: Israel

1. The Israel Government, Office of Energy

2.

3.

22. Contact for written copy of energy standard specified in Question 4:

Neme:

Address:

Country:

Tel:

Fax:

Types of supporting information available:

Commentary for the Israeli Standard; Technical Institution for Building Research; Prof. A. Bentur; tel:972 292242; fax: 9724324534

Other energy standards for non-residential buildings:

- None

Survey completed by: Eng. Raya Hizi

Title: Head of Building Branch

Standards Institution of Israel

Standardization Deparment, 42 Chaim Levanon St.

Tel-Aviv

Country: Israel

Tel: $\quad 972-3-545-4154$

Fax: $972-3-412-762$

Date completed: $\quad 5 / 13 / 92$ 


\section{IVORY COAST}

\section{GENERAL OVERVIEW OF BUILOING ENERGY STANDARDS}

1. General building standards exist at the following governmental levels:

National

2 Proposed or existing ENERGY standards cover the following building sectors: Both Residential and Non-Residential

3. Status of Non-Residential Building Energy Standards at the:

a National level:

Proposed

b. Regional level:

c. Local level:

$\longrightarrow$

4. Single energy standard selected for further description:

Titte, Organization: "Code de Qualite Energetique des Batiments", 1992. (Energy Efficiency Code, Draft Version). Ministere des Mines et de L'energie, Bureau des Economies d'Energie. Plan to be developed by Spring 1993.

Year: 1992

Ceographic Coverage: Nation

Abbreviated Title: IC-1993

\section{DESCRIPTION OF SPECIFIED ENERGY STANDARDS - IL-1993}

5. The standard defined in Question 4 applies to the following kinds of buildings:

a. Building types:

A - All Buildings b. Building vintage:

Both new and existing

c. Other characteristics:

A - Air-Conditioned

O - Other: natural ventilation

6. Basic approach of the standard: Both prescriptive and performance

7. The following subjects are included in the energy standard:

a. Whole building energy provisions:

E- Energy amount target

C- Energy cost target

c. Lighting provisions:

Control requirements

Power density

Illumination requirements: recommendations

e. Other provisions:

Yes:electrical specifications. b. Building envelope provisions:

Roof

Wall system

Fenestration system

\section{d. Mechanical provisions:}

Air/Water distribution efficiency

Load Calculations for equipment sizing

Controls

Ventilation

Equipment efficiency 


\section{Organizations involved in developing the standard:}

Government agency: Bureau des Economies d'Energie

Academic institution: E.N.S.T.P.

Foreign development agency: ESMAP/ACDI

9. Decision Process: Consensus

Comment

10. Information used in developing the standard:

a. PHYSICAL CHARACTERISTICS of existing buildings

Estimated using professional judgment

Gathered through audits and surveys

Already available prior to standard

\section{c. WEATHER data}

Gathered through measurements

Already available prior to standard

11. Standards from a different country used as source material:

Jamaica: EEBC-92

\section{b. ENERGY LSE of existing buildings:}

Estimated using professional judgment

Computer simulations used for estimates

Gathered through audits and surveys

\section{d. Other information}

-None

12. COMPUTER programs used:

a In developing the standard:

OASIS

CODYBA

DOE-2

13. Standard is set at a level: Above current practice

\section{Considerations influencing the inclusion or exclusion of measures in the standard:}

E - Cost effectiveness

A - Availability of energy efficient products

$\mathrm{S}$ - Similarity/difference to local design

C-Comfort

\section{5a. Standard scheduled for regular review and revision?}

Unsure: do not know the answer, as this will be the first standard. But given the French approach, safe bet this will happen.

b. Does revision include procedures to MONITOR and EVALUATE earlier versions of the standard?

$\mathrm{No}$ 
16. Entities involved in MPLEMENTING energy standards:

Existing agency: Eiureau des Economies d'Energie

If an existing agency was made responsible for implementation, its former focus was on buildings, energy, or another area:

Energy

17. TRANING \& EDUCATION provided for architects, engineers and other professionals:

Written guidelines to assist with compliance procedure

Example calculations

Compliance forms

Seminars, workshops, or conferences

18. Compliance mechanisms used at different stages in construction process:

a. PRIOR to construction:

Percent designs checked: -

Comment:

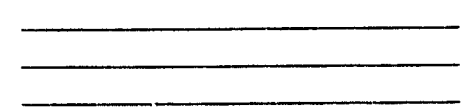

b. DURING construction:

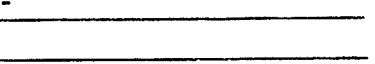

Percent sites checked: -

Comment:

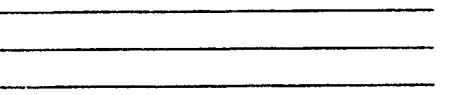

c. AFTER construction:

Percent buildings checked: Comment:

d. Other compliance procedures

e. Effectiveness of combined compliance mechanisms (scale of 1-5):

f. Explanation for effectiveness in part e:

19. Types of assessments or audits of energy standards' impact:

a. ENERGY SAVINGS POTENTIAL based on protoly rical (not actual) buildings:

In progress

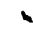

b. MEASUREMENTS OF ENERGY SAVINGS in actual buildings complying with standard:

$-$

c. COST EFFECTIVENESS based on engineering economic CALCULATIONS:

In progress

d. COST EFFECTIVENESS based on ACTUAL COSTS:

e. Other Assessments: 
20. Efficiency testing facilities and procedures established:

Other: There is a building research and testing facility, but not for energy

21. Other programs or policies developed to increase energy efficiency in buildings:

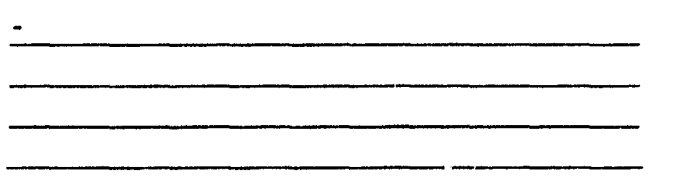

Comment:

Additional sources of information about energy efficiency for buildings in: Ivory Coast

1.

2.

3.
$=$

$=$

22. Contact for written copy of energy standard specified in Question 4:

Name

Address:

Country:

Tel:

Fax:

Types of supporting information available:

Other energy standards for non-residential buildings:

Survey completed by: Jean Thibon

Title: Ingenieur E.N.S.I.G.C

Bureaux des Economies Enérgies

B.P. 2541

Abijan 01

Country: Ivory Coast

Tel: not on file, please

Fax: not on file, please send

Date completed: $\quad 3 / 20 / 92$ 


\section{JAMAICA}

\section{GENERAL OVERVIEW OF BUILDING ENERGY STANDARDS}

1. General building standards exist at the following governmental levels:

National

2. Proposed or existing ENERGY standards cover the following building sectors: Non-Residential Only

3. Status of Non-Residential Building Energy Standards at the:

a National level: Mandatory (G)

$$
\text { Voluntary (all }
$$

b. Regional level:

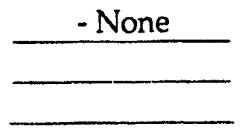

c. Local level: __ - None

\section{Single energy standard selected for further description:}

Title, Organization: Energy Efficiency Bujilding Code (EEBC-92), October 1992. Jamaica Bureau of Standards

Year: 1992

Geographic Coverage: ___ Nation

Abbreviated Title: EEBC-92

\section{DESCRIPTION OF SPECIFIED ENERGY STANDARDS - EEBC-92}

5. The standard defined in Question 4 applies to the following kinds of buildings:

a. Building types:
$\frac{O \text { - Offices }}{\mathrm{H} \text { - Hotels }}$
$\frac{\mathrm{G} \text { - Government Facilities }}{\mathrm{F} \text { - Restaurants }}$
$\frac{\mathrm{D} \text { - Hospitals }}{\mathrm{R} \text { - Religion-related }}$
$\frac{\mathrm{C}-\text { Multi-family residential }}{}$

b. Building vintage:

Both new and existing

C. Other characteristics:

P - Physical size: $>93$ sq. meter of floor area

E - Amount of energy: $>11 \mathrm{~W} /$ sq. meter

A - Air-Conditioned

6. Basic approach of the standard: Both prescriptive and performance

7. The following subjects are included in the energy standard:

a Whole building energy provisions:

E- Energy amount target

C- Energy cost target

\section{c. Lighting provisions:}

Control requirements

Power density

Illumination requirements: recommendations

e. Other provisions:

Yes: electrical specifications, theromostat settings, and energy management. b. Building envelope provisions:

Roof

Wall system

Fenestration system

\section{d. Mechanical provisions:}

Air/Water distribution efficiency

Load Calculations for equipment sizing

Controls

Ventilation

Equipment efficiency 


\section{STANDARDS DEVELOPMENT PROCESS - EEBC-92}

8. Organizations involved in developing the standard:

Government agency: Jamaica Bureau of Standards; Ministry of Mines and Energy; Kingston Town Planning Local interest group: Jamaica Institute of Engineers; Jamaica Institute of Architects; EEBC Review Committee Industry group: Jamaica Public Service Co. (elec. util.); many local suppliers

Academic institution: University of West Indies

Foreign development agency: World Bank, ESMAF; Dublin Bloome \& the Deringer Group

9. Decision Process: Consensus

Comment

10. Information used in developing the standard:

\section{a. PHYSICAL CHARACTERISTICS of existing buildings}

Estimated using professional judgment

Gathered through audits and surveys

Already available prior to standard

\section{c. WEATHER data}

Gathered through measurements

11. Standards from a different country used as source material:

USA: ASHRAE 90.1-1989

Malaysia

Thailand

Philippines

Indonesia

\section{b. ENERGY USE of existing buildings:}

Estimated using professional judgment Computer simulations used for estimates Already available prior to standard

\section{d. Other information}

Yes: See Energy and Economic Analysis Report in Support of EEBC-92 by I. Cumper \& S. Marslim, 1992.

12. COMPUTER programs used:

a In developing the standard:

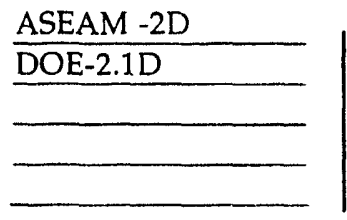

b. For complying with the standard: Yes

Yes

13. Standard is set at a level: Above current practice: $30-35 \%$ above current

14. Considerations influencing the inclusion or exclusion of measures in the standard:

E - Cost effectiveness

A - Availability of energy efficient products

$\mathrm{S}$ - Similarity/difference to local design

C-Comfort

Comments:

15a. Standard scheduled for regular review and revision?

$\mathrm{NR}$

b. Does revision include procedures to MONTOR and EVALUATE earlier versions of the standard?

NR 
16. Entities involved in IMPLEMENTING energy standards:

Existing agency: Jamaica Bureau of Standards (plus other agencies involved in development)

\section{If an existing agency was made responsible for implementation, its former focus was on buildings, energy, or another area:}

Buildings

17. TRAINING \& EDUCATION provided for architects, engineers and other professionals:

Written guidelines to assist with compliance procedure

Example calculations

Compliance forms

Seminars, workshops, or conferences

Information or resource center

18. Compliance mechanisms used at different stages in construction process:

a. PRIOR to construction:

Certification/approval

Percent designs checked: ?

Comment:

Certification is powerful in English tradition (strong in

Jamaica) b. DURING construction:

Percent sites checked:

Comment:

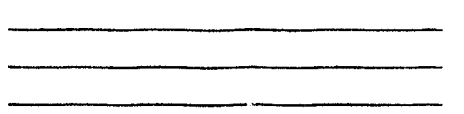

c. AFTER construction:

$\longrightarrow$

Percent buildings checked:

Comment:

\section{d. Other compliance procedures}

e. Effectiveness of combined compliance mechanisms (scale of 1-5):

f. Explanation for effectiveness in part e:

19. Types of assessments or audits of energy standards' impact:

a. ENERGY SAVINGS POTENTIAL based on prototypical (not actual) buildings:

Completed: J. Deringer \& J. Gilling, ACEEE Proceedings, 1992.

b. MEASUREMENTS OF ENERGY SAVINGS in actual buildings complying with standard:

In progress

c. COST EFFECTIVENESS based on engineering economic CALCULATIONS:

Completed: J. Deringer \& J. Gilling, ACEEE Proceedings, 1992.

d. COST EFFECTIVENESS based on ACTUAL COSTS:

?

e. Other Assessments: Completed: Building Sample 1987-8 


\section{FURTHER INFORMATION ON ENERGY CONSERVATION - Jamaica}

20. Efficiency testing facilities and procedures established:

Air conditioners/chillers/other appliances

21. Other programs or policies developed to increase energy efficiency in buildings:

Information programs

Government energy policy: DSM

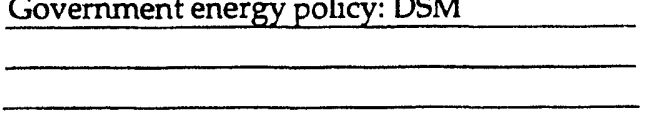

Additional sources of information about energy efficiency for buildings in: Ja maica

1.

2.

3.

22. Contact for written copy of energy standard specified in Question 4:

Name Joe Gilling

Address: ESMAP

Country:

Tel:

Fax:

Types of supporting information available:

Other energy standards for non-residential buildings:

Survey completed by: Roosevelt DaCosta

Title: Group Director, Engineering

Jamaica Bureau of Standards

6 Winchester

Kingston 10

Tel: $\quad 809$ 926-3140

Fax: 8099294736

Date completed: $\quad 10 / 30 / 92$
Country: Jamaica

\section{61}




\section{GENERAL OVERVIEW OF BUILDING ENERGY STANDARDS}

1. General building standards exist at the following govemmental levels:

National

Local

2. Proposed or existing ENERGY standards cover the following building sectors: Both Residential and Non-Residential

3. Status of Non-Residential Building Energy Standards at the:

a National level:

$\frac{\text { Mandatory }}{\text { Voluntary }}$

b. Regional level:

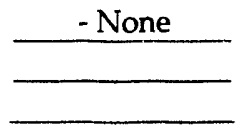

c. Local level: __ - None

4. Single energy standard selected for further description:

Title, Organization: "Standards of Owner's Evaluation Regarding the Rationalization of Energy Use in Buildings for Office Use" Ministry of International Trade and Industry; Ministry of Construction.

Year: 1980 Geographic Coverage: Nation Abbreviated Title: MITI, 1980

\section{DESCRIPTION OF SPECIFIED ENERGY STANDARDS - MMTI, 1980}

5. The siandard defined in Question 4 applies to the following kinds of buildings:

a. Building types:

Offices

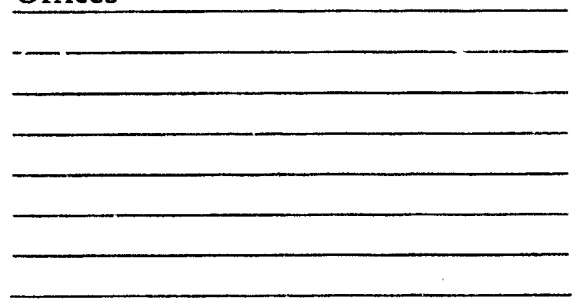

b. Building vintage:

New buildings

c. Other characteristics:

P - Physical size: $>2000$ sq. $m$

6. Basic approach of the standard: Performance-based

7. The following subjects are included in the energy standard:

a. Whole building energy provisions:

- None

\section{c. Lighting provisions:}

Other: covered in Japanese industrial standard

e. Other provisions:

Yes: thermostat setting-voluntary standard in Summer $28 \mathrm{deg} . \mathrm{C}$, Winter $20 \mathrm{deg} . \mathrm{C}$

\section{b. Building envelope provisions:}

Roof

Wall system

Fenestration system

Infiltration

d. Mechanical provisions:

- None

C - 62 


\section{Organizations involved in developing the standard:}

Government agency: Ministry of International Trade and Industry/Ministry of Construction

Other: Energy Conservation Center

Other: Institute of Building Energy Conservation

9. Decision Process: Mandate

10. Information used in developing the standard:

a. PHYSICAL CHARACTERISTICS of existing buildings

Already available prior to standard

\section{c. WEATHER data}

Already available prior to standard

11. Standards from a different country used as source material:

Uncertain

\section{Comment: Ministry held a council}

\section{b. ENERGY USE of existing buildings:}

Already available prior to standard

\section{d. Other information}

-None

12. COMPUTER programs used:

\begin{abstract}
a In developing the standard:
\end{abstract}

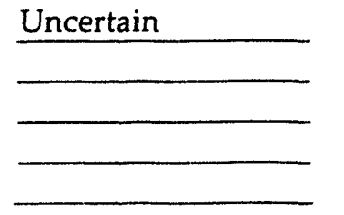

b. For complying with the standard: Yes

Each constructor has program.

13. Standard is set at a level: Above current practice

\section{Considerations influencing the inclusion or exclusion of measures in the standard:}

E - Cost effectiveness

Similarity/difference to local design

No: not regularly

b. Does revision include procedures to MONTOR and EVALUATE earlier versions of the standard?

Yes: maybe?

\section{5a. Standard scheduled for regular review and revision?}

Comments:

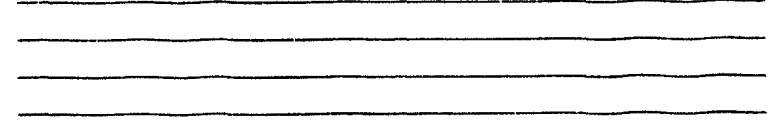

Yesi maybe? 
IMPLEMENTATION AND COMPLIANCE - MIT, 1980

16. Entities involved in IMPLEMENTING energy standards:

Existing agency: local offices of the Ministry of Construction

If an existing agency was made responsible for implementation, its former focus was on buildings, energy, or another area:

Buildings

17. TRAINING \& EDUCATION provided for architects, engineers and other professionals:

Written guidelines to assist with compliance procedure

Seminars, workshops, or conferences

Information or resource center

18. Compliance mechanisms used at different stages in construction process:

a. PRIOR to construction:

Certification/approval

Percent designs checked: 100 Comment

All office buildings with floor space above $2000 \mathrm{sq} . \mathrm{m}$. b. DURING construction:

No mechanism

Percent sites checked:

Comment:

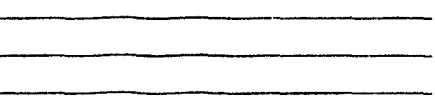

\section{c. AFTER construction:}

No mechanism

Percent buildings checker:

Comment:

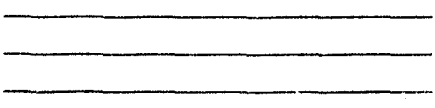

d. Other compliance procedures

e. Effectiveness of combined compliance mechanisms (scale of 1-5): 5

f. Explanation for effectiveness in part e:

19. Types of assessments or audits of energy standards' impact:

a. ENERGY SAVINGS POTENTIAL based on prototypical (not actual) buildings:

None conducted

b. MEASUREMENTS OF ENERGY SAVINGS in actual buildings complying with standard:

C. COST EFFECTIVENESS based on engineering economic CALCULATIONS:

$-$

d. COST EFFECTIVENESS based ON ACTUAL COSTS:

e. O'ther Assessments: Done by constructors voluntarily 


\section{FURTHER INFORMATION ON ENERGY CONSERVATION - Japan}

\section{Efficiency testing facilities and procedures established:}

\section{Motors}

Insulation

Air conditioners/chillers/other appliances

Thermal properties of materials

\section{Other programs or policies developed to increase energy efficiency in buildings:}

Information programs

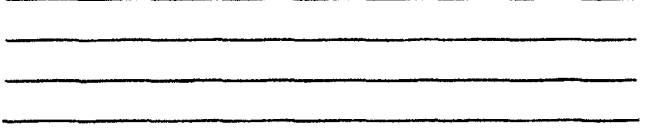

Comment Japanese-language sample of information campaign enclosed.

\section{Additional sources of information about energy efficiency for buildings in: Japan}

1. Iournal of "The Society of Heating, Air-Conditioning, and Sanitary Engineers of Japan," address: Kirashinjuke 1-8-1, Shinjuku-ku, Tokyo. Tel: 81333638261

2. The Magazine of Building Equipment. Address:Nihonbaski Hon-Machi 4-14-2 Chiioku, Tokyo. Tel: 81 336684059

3.

22. Contact for written copy of energy standard specified in Question 4:

Name:

Address: $\quad$ Agency of National Resources and Energy

Ministry of International Trade and Industry

Chiyodaku; Kasumigaseki 1-3-1 Tokyo

Country: Japan

Tel: $\quad 81335-01-1511$

Fax: $\quad 8133580-8439$

Types of supporting information available:

Other energy standards for non-residential buildings:

-None

Survey completed by: Misuo Iguchi

Title: Senior Technical Advisor

Energy Conservation Center

2-39-3, Nishi-Shinbashi

Minato-Ku

Tokyo Country: Japan 105

Tel: $81-3-3433-0312 \quad$ Fax: $81-3-3433-0393$

Date completed: $\quad 3,31 / 92$

\section{65}


CENERAL OVERVIEW OF BUILDIIG ENERGY STANDARDS

1. General building standards exist at the following govemmental levels:

National

Regional

Local

2. Proposed or existing ENERGY standards cover the following building sectors: Non-Residential Only

3. Status of Non-Residential Building Energy Standards at the:

b. Regional level:

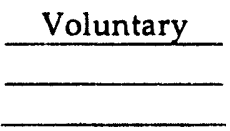

c. Local level: Voluntary

4. Single energy standard selected for further description:

Title, Organization: "Guidelines for Energy Efficiency in Buildings", Ministry of Energy Telecommunications, and Posts.

Year: 1989 Geographic Coverage: Nation Abbreviated Title: GEEB-METP, 1989

DESGRIPTION OF SPECIFIED ENERGY STANDARDS - GEEB-METP, 1989

5. The standard defined in Question 4 applies to the following kinds of buildings:

a. Building types:

O - Offices

H - Hotels

G - Government Facilities

F-Restaurants

C - Commercial/retail stores b. Building vintage:

New Buildings

c. Other characteristics:

E - Amount of energy: peak design rate $>10 \mathrm{~W} / \mathrm{m} 2$ (installed)

6. Basic approach of the standard: Performance-based

7. The following subjects are included in the energy standard:

a. Whole building energy provisions:

- None

c. Lighting provisions:

Control requirements

Power density

Illumination requirements

e. Other provisions:

-None b. Building envelope provisions:

Roof

Wall system

Fenestration system

Infiltration

d. Mechanical provisions:

Load calculations for equipment sizing Controls

Equipment efficiency 


\section{Organizations involved in developing the standard:}

Government agency: Ministry of Energy, Telecommunications and Posts, Malaysia

Academic institution: Universiti Technologi, Malaysia

9. Decision Process: Consensus

10. Information used in developing the standard:

a. PHYSICAL CHARACTERISTICS of existing buildings

Gathered through audits and surveys

\section{c. WEATHER data}

Already available prior to standard

11. Standards from a different country used as source material:

Singapore: Building Regulations USA: ASHRAE 90.1P
Comment Professional institutions (e.g, engineering, architecture); Building organizations/associations

\section{b. ENERGY USE of existing buildings:}

Gathered through audits and surveys

Already available prior to standard

\section{d. Other information}


16. Entities involved in IMPLEMENTING energy standards:

Voluntary standards; no agency

If an existing agency was made responsible for implementation, its former focus was on buildings, energy, or another area:

\section{TRANING \& EDUCATION provided for architects, engineers and other professionals:}

Example calculations

Seminars, workshops, or conferences

18. Compliance mechanisms used at different stages in construction process:

a. PRIOR to construction:

No mechanism

Percent designs cheoked: Comment:

d. Other compliance procedures

e. Effectiveness of combined compliance mechanisms (scale of 1-5):

f. Explanation for effectiveness in part e:

19. Types of assessments or audits of energy standards' impact:

a. ENERGY SAVINGS POTENTIAL based on prototypical (not actual) buildings:

Completed: "Energy and Economic Analysis of Commercial Buildings Standards in Malaysia." J.J. Deringer,

b. MEASUREMENTS OF ENERGY SAVINGS in actual buildings complying with standard:

Planned

c. COST EFFECTIVENIESS based on engineering economic CALCULATIONS:

Completed: see above

d. COST EFFECTI FENESS based ON ACTUAL COSTS:

Completed

e. Other Assessments:
C. AFTER construstion:

No mechanism

Percent buildings checked:

Comment: 


\section{Efficiency testing facilities and procedures established:}

Motors

Insulation

Air conditioners/chillers/other appliances

Ballasts

21. Other programs or policies developed to increase energy efficiency in buildings:

Information programs: Ministry of Energy,

Audits: Ministry of Energy,

Energy Efficiency Training: Ministry of

Comment

\section{Additional sources of information about energy efficiency for buildings in: Mala ysia}

1. Seminar papers and compiled manual for energy efficiency.

2.

3.

22. Contact for written copy of energy standard specified in Question 4:

Name

Address: Energy Unit

Ministry of Energy, Telecommunications, and Posts

Wisma Damansara, Jalan Semantran

50668 Kuala Lumpar

Country: Malaysia

Tel: 60-3-2562222 Fax: 60-3-255-7901

Types of supporting information available:

Other energy standards for non-residential buildings:

none

Survey completed by: K.S. Kannan

Title: Faculty of Mechanical Engineering

Universiti Teknologi Malaysia

Karung Berkunci 791; 80990 Johor Bahru

Johor Drul Takzim

Country: Malaysia

Tel: $\quad 60-7-561-601 / 2 / 3 \quad$ Fax: $60-7-572-555$

Date completed: $\quad 3 / 31 / 92$ 


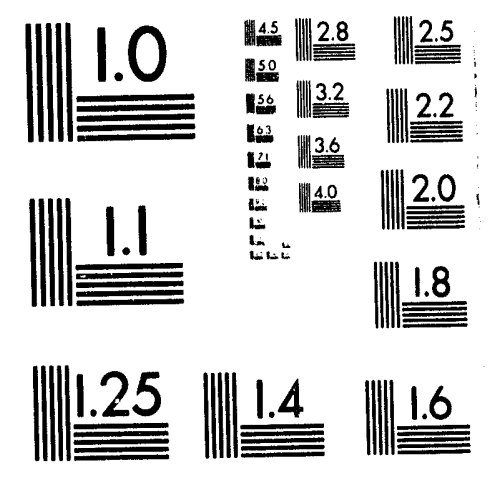



GENERML OVERVEW OF BUILDWG ENERGY STAWDARDS

1. General building standards exist at the following governmental levels:

National

Local

2. Proposed or existing ENERGY standards cover the following building sectors: Both Residential and Non-Residential

3. Status of Non-Residential Building Energy Standards at the:

a National level:

Proposed

b. Regional level:

- None

c. Local level: Mandatory

4. Single energy standard selected for further description:

Title, Organization: Bowwbersluit, Effective July 1, 1992

Year: 1992 Ceographic Coverage: Nation Abbreviated Title: Bouwbersluit, 1992

\section{BESORIPIDN OF SPEGIFED ENERGY ST WDARDS- Bouwbersluit, 1992}

5. The standard defined in Question 4 applies to the following kinds of buildings:

a. Building types:

O- Offices

H - Hotels

$S$ - Single-family residential

M - Multi-family residential

D - Hospitals

E - Educational facilities (schools)

\section{b. Building vintage:}

Both new and existing

c. Other characteristics:

6. Basic approach of the standard: Performance-based

7. The following subjects are included in the energy standard:

a. Whole building energy provisions:

- None

c. Lighting provisions:

- None

e Other provisions: b. Buiking envelope provisions:

Roof

Wall system

Fenestration system

Infiltration

\section{d. Nechanical provisions:}

Other: efficiency of natural gas boilers for rooms

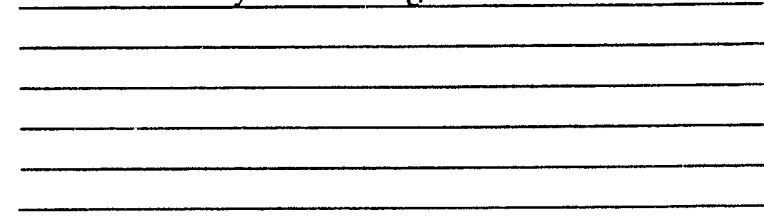


STANDARDS DEVELOPIENT PROCESS - Bouwbershit, 1992

\section{Organizations involved in developing the standard:}

Government agency: Ministry of Housing and the Environment

Government agency: Ministry of Economic Affairs

Research group: Novem TNO

Other: NNI - standards commission - representation of all interested groups who design standard

9. Decision Prosess: Consensus

10. Information used in developing the standard:

a. PHYSICAL CHARACTERISTICS of existing buildings

Already available prior to standard

\section{c. WEATHER data}

Already available prior to standard

11. Standards from a different country used as source material:

- None
Comment Calculations and descriptions were consensus, but the NNI commission (and the government) made the levels manatory

12. COMPUTER programs used:

a In developing the standard:

$\frac{\text { CEN TC } 89}{\underline{\text { TCM }}}$

\section{b. ENERGY USE of existing buildings:}

Not available, not used in standard

\section{d. Other information}

-None

13. Standard is set at a level: Equal to current practice

14. Considerations influencing the inclusion or exclusion of measures in the standard:

E - Cost effectiveness

Comfort b. For complying with the standard: No

\section{5a. Standard scheduled for regular review and revision?}

Yes: Until July 1, 1992, revision every year. The level of revision depends merely on the National Targets for Energy -Saving and the cost effectiveness. Technological improvement is not a goal.

\section{b. Does revision include procedures to MONTOR and EVALUATE earlier versions of the standard?}

No 


\section{NETHERLANDS}

\section{MPLEMENTATION AND COMPLIANCE - Bouwbersluit, 1992}

16. Entities involved in IMPLEMENTING energy stan s- rds:

Existing agency: all local communities

If an existing agency was made responsible for implementation, its former focus was on buildings, energy, or another area:

Buildings

17. TRAINING \& EDUCATION provided for architects, engineers and other professionals:

Written guidelines to assist with compliance procedure

Example calculations

Compliance forms

Information or resource center

18. Compliance mechanisms used at different stages in construction process:

a. PRIOR to construction:

Certification/approval

Percent designs checked: 100

Comment:

Approval required to become the license for construction b. DURANG construction:

Penalty

Percent sites checked: 10 Comment

Penalty consists of no permission to finish construction. c. AFTER construction:

No mechanism

Percent buildings checked: 0 Comment:

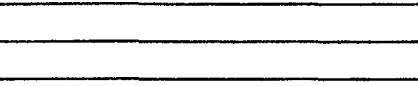

d. Other compliance procedures - None

e. Effectiveness of combined compliance mechanisms (scale of 1-5):

f. Explanation for effectiveness in part e: License is needed before starting construction. Inspection during construction. is very simple.

19. Types of assessments or audits of energy standards' impact:

a. ENERGY SAVINGS POTENTIAL based on prototypical (not actual) buildings:

Completed: National Environmental Plan Plus (NMP+), 1990.

Completed: Noto Energiebesparing, 1990.

b. MEASUREMENTS OF ENERGY SAVINGS in actual buildings complying with standard:

None conducted

c. COST EFFECTIVENESS based on engineering economic CALCULATIONS:

Completed: Novem, Voorbaldpahhater. Ministry of Housing.

d. COST EFFECTIVENESS based on ACTUAL COSTS:

None conducted

e. Other Assessments: Planned 


\section{FURTHER WFORMATION ON ENERGY CONSERVATION - Netherlands}

20. Efficiency testing tacilities and procedures established:

Insulation

Air conditioners/chillers/other appliances: white goods, boilers

Thermal properties of maitarials

Other: boilers

21. Other programs or policies developed to increase energy efficiency in buildings:

Information programs

Utility initiatives

Rebates

Audits (free or subsidized)
Comment Ministry of Housing and Environment/Economic Affairs; all utilities (Milieu Aklie Plan); subsidies in existing buildings; awareness campaign in all governmental buildings by Norram and MAinictry of Herrciner

Additional sources of information about energy efficiency for buildings in: Netherlands

1. Environmental Action Plan from the utilities. (English)

2. National Environmental Plan and Noto Energiebesporing, Ministry of Housing and Environment (English)

3. Lecture: "Regulations for the Energy Performance of Buildings: a Status Quo" by S. REnes, Government Building Agency, Ministry of Housing (Available in English by request, R. Trines)

\section{Contact for written copy of energy standard specified in Question 4:}

Name H.L. von Duijze

Address: Ministry of Housing

Box 3001

2700 KA Zosterman

Country: The Netherlands

$\begin{array}{lll}\text { Tel: } \quad 3179272003 & \text { Fax: } \quad 3179516431\end{array}$

Types of supporting information available:

Other energy standards for non-residential buildings:

Yes: Building Standards for Governmental Buildings, Government Buildings Agency.

(from above) Minn S. Renes; Box 20952; 2500 E2 Don Hoog; tel: 3170 356 7890; fax: 31703567588

\section{Survey completed by: Ruud Trines \\ Title: Project-Manager \\ Novem Sittard \\ Swentiboldstraat 21 \\ P.O. Box 17,6130 AA \\ Tel: $\quad 31-0-46-595-318$}

Date completed: $\quad 4 / 10 / 92$
Sittard Country: The Netherlands

Fax: $31-0-46-528-260$ 


\section{GENERML OVERVEW OF BUILDING ENERGY STANDARDS}

1. General building standards exist at the following govemmental levels:

National

2. Proposed or existing ENERGY standards cover the following building sectors: Both Residential and Non-Residential

3. Status of Non-Residential Building Energy Standards at the:
a National level:
Mandatory
b. Regional level:
- None
c. Local level: _ - None

\section{Single energy standard selected for further description:}

Title, Organization: Building Industry Authority, Approved Document H1. (refers to NZS 4220: Code of Practice for Energy Conservation in Non-Residential Buildings)

Year: 1982

Geographic Coverage: Nation

Abbreviated Title: BIA H1

\section{DESCRIPTION OF SPECIFIED ENERGY STANDARDS - BIA H1}

5. The standard defined in Question 4 applies to the following kinds of buildings:

a. Building types:

O - Offices

H - Hotels

G - Government Facilities

D - Hospitals

C - Commercial/retail stores

$\mathrm{R}$ - Religion-related b. Building vintage:

Both new and existing

c. Other characteristics:

P - Physical size: $>50$ sq. $\mathrm{m}$

6. Basic approach of the standard: Both prescriptive and performance

7. The following subjects are included in the energy standard:

a. Whole building energy provisions:

E-Energy amount target

c. Lighting provisions:

Power density

e Other provisions:

Nogaals or targets presently set for non-residential buildings

\section{b. Bulding envelope provisions:}

Roof

Wall system

Fenestration system

Infiltration

\section{d. Mechanical provisions:}

Load Calculations for equipment sizing

Controls

Ventilation 


\section{Organizations involved in developing the standard:}

Government agency: Building Industry Authority

Research group: Building Research Association of New Zealand

9. Decision Process: Mandate

Comment Decree taking into account public comment

10. Information used in developing the standard:

a. PHYSICAL CHARACTERISTICS of existing buildings

Gathered through audits and surveys Already available prior to standard

\section{c. WEATHER data}

Already available prior to standard

11. Standards from a different country used as source material:

USA: ASHRAE - Handbook of Fundamentals

UK:

BS 5422: 1977

IHVE Guide Books

UK: CIBS Energy Codes

12. COMPUTER programs used:

a In developing the standard

\section{SUSTEP}

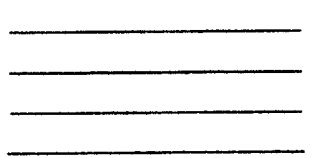

b. ENERGY USE of existing buildings:

Computer simulations used for estimates Gathered through audits and surveys

\section{d. Other information}

-None

b. For complying with the standard: ALF

13. Standard is set at a level: Equal to current practice

14. Considerations influencing the inclusion or exclusion of measures in the standard:

E - Cost effectiveness

Similarity/difference to local design

Comments:

15a. Standard scheduled for regular review and revision?

Yes: when BIA has funding, $\mathrm{H1}$ will be subject to full technical and committee review

b. Does revision inciude procedures to MONTOR and EVALUATE earlier versions of the standard?

No 


\section{NEW ZEALAND}

\section{IMPLEMENTATION ANO COMPLANCE - BIA HI}

16. Entities involved in MPPLMENTING energy standards:

Existing agency: Building Industry Authority

If an existing agency was made responsible for implementation, its former focus was on buildings, energy, or another area:

Buildings

17. TRAINING \& EDUCATION provided for architects, engineers and other professionals:

Other: training expected to be provided by industry

18. Compliance mechanisms used at different stages in construction process:

a. PRIOR to construction:

Certification/approval

Percent designs checked: 90

Comment:

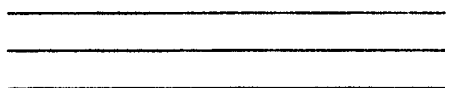

b. DURING construction:

Certification/approval

Percent sites checked: 25

Comment:

Small buildings $100 \%$; Large buildings about $25 \%$ c. AFTER construction:

Certification/approval

Percent buildings checked: 100 Comment:

Territorial authority m!ss give a code compliance certificate

d. Other compliance procedures NB: Building code is administered by territorial authorities.

e. Effectiveness of combined compliance mechanisms (scale of 1-5): 4

f. Explanation for effectiveness in part e:

19. Types of assessments or audits of energy standards' impact:

a. ENERGY SAVINGS POTENTIAL based on prototypical (not actual) buildings:

Planned

b. MEASUREMENTS OF ENERGY SAVINGS in actual buildings complying with standard:

Completed: Baird, Brander, Bruhns, Donn, Isaacs, Pool, in Architecture at Victoria University, Wellington. Completed: Other reports on CBD building energy use in Auckland and Christchurch

c. COST EFFECTIVENESS based on engineering economic CALCULATIONS:

Planned

d. COST EFFECTIVENESS based on ACTUAL COSTS:

Planned

e. Other Assessments: None conducted 


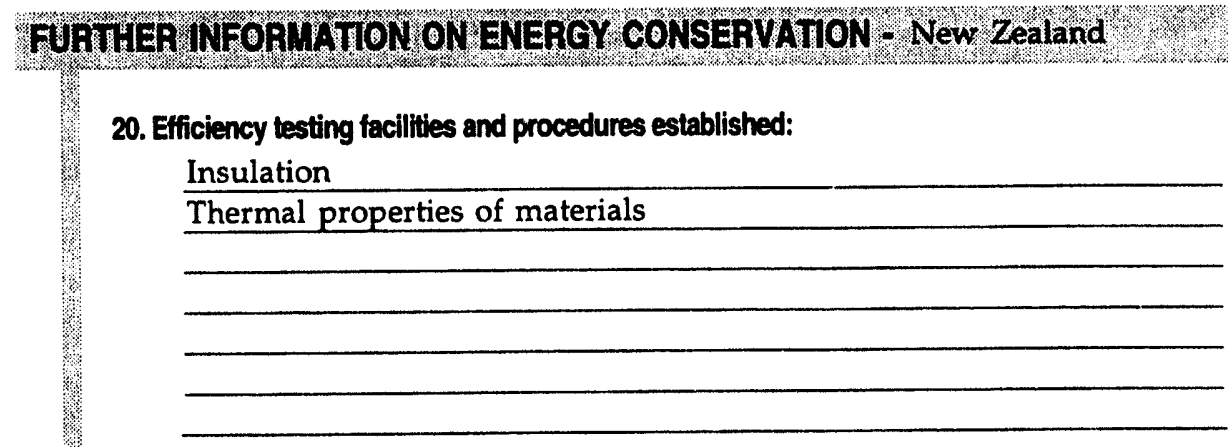

21. Other programs or policies developed to increase energy efficiency in buildings:

Utility initiatives

$\longrightarrow$

comment The major electricity generating utility has developed an "Energy Efficient House" program that includes management and appliances.

Additional sources of information about energy efficiency for buildings in: New Zealand

1. Building Research Association of New Zealand. ALE Manual.

2. Baird, Donn, Pool, Brander \& Chan. "Energy Performance of Buildings," CRC Press, Boca Raton, Elorida. 1983. (New Zealand commercial buildings)

3.

22. Contact for written copy of energy standard specified in Question 4:

Neme:

Address:

Standards Association of New Zealand

Private Bag, Wellington

Country:

Tel:

Fax:

Types of supporting information available:

Building Code Performance, from Hamish Handley.

Other energy standards for non-residential buildings:

NZD 4220

\begin{tabular}{|c|c|}
\hline $\begin{array}{r}\text { Survey completed by: } \\
\text { Title: }\end{array}$ & $\begin{array}{l}\text { Nigel Isaacs } \\
\text { Research Fellow } \\
\text { Centre for Building Performance Research } \\
\text { School of Architecture, Victoria University of } \\
\text { PO Box } 600 \quad \text { Wellingto Country: New Zealand }\end{array}$ \\
\hline Tel: & Fax: 6444955233 \\
\hline Date completed: & $12 / 13 / 92$ \\
\hline
\end{tabular}




\section{CENERML OVERVEW OF BUILDING ENERGY STANDARDS}

1. General building standards exist at the following govemmental levels:

National

2. Proposed or existing ENERGY standards cover the following building sectors: Both Residential and Non-Residential

3. Status of Non-Residential Building Energy Standards at the:

a National level: Mandatory

b. Regional level:

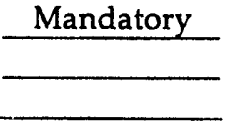

c. Local level: Mandatory

\section{Single energy standard selected for further description:}

Title, Organization: Building Regulations (Northern Ireland) 1990 plus amendment Part E, Conservation of Fuel and Power July 1, 1991. Department of the Environment for Northern Ireland

Year: 1991

Geographic Coverage: Nation

Abbreviated Title: BR-DENI, 1991

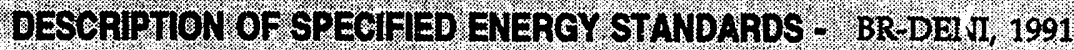

5. The standard defined in Question 4 applies to the following kinds of buildings:

a. Building types:

A - All Buildings

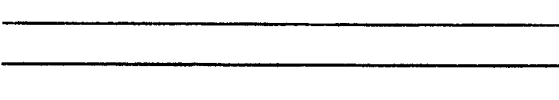

b. Building vintage:

Both new and existing

c. Other characteristics:

P - Physical size: non-residential $>30$ sq. $\mathrm{m}$ floor area

$\mathrm{E}$ - Amount of energy: Industrial or storage $>50 \mathrm{~W} / \mathrm{sq} . \mathrm{m}$ other buildings $>25 \mathrm{~W} / \mathrm{sq} . \mathrm{m}$

6. Basic approach of the standard: Performance-based

7. The following subjects are included in the energy standard:

a. Whole building energy provisions:

- None

c. Lighting provisions:

- None

e. Other provisions:

\section{b. Building envilope provisions:}

$$
\begin{aligned}
& \text { Roof } \\
& \hline \text { Wall system } \\
& \hline \text { Fenestration system }
\end{aligned}
$$

d. Mecharical provisions:

Controls

-None 


\section{Organizations involved in developing the standard:}

Governn ent agency: Department of the Environment for Northern Ireland Government agency: Department of the Environment (England and Wales)

Research group: Building Research Establishment

9. Decision Process: Consensus

Comment Public consultation on proposals.7

10. Information used in developing the standard:

a. PHYSICAL CHARACTERISTICS of existing buildings

Gathered through audits and surveys

\section{c. WEATHER data}

Already available prior to standard

\section{Standards from a different country used as source material:}

England and

Wales:

12. COMPUTER programs used:

a In developing the standard:

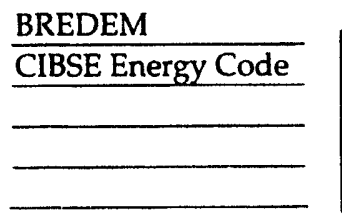

b. ENERGY USE of existing buildings:

Gathered through audits and surveys

\section{d. Other information}

-None

b. For complying with the standard: No

13. Standard is set at a level: Above current practice

14. Considerations influencing the inclusion or exclusion of measures in the standard:

E - Cost effectiveness

comments:

Availability of energy efficient products

Similarity/difference to local design

Cost effectiveness

Other:

\section{5a. Standard scheduled for regular review and revision?}

Yes: $B R E$ research leads to proposals $\Rightarrow>$ public consultation $\Rightarrow 2$ final proposals $\Rightarrow 2$ ministerial approval $\Rightarrow E C$ notification $=>$ regulations made.

\section{b. Does revision include procedures to MONITOR and EVALUATE earlier versions of the standard?}

Yes: Building Research Establishment undertakes this on our behalf. 
16. Entities involved in IMPLEMENTING energy standards:

Existing agency: Department of the Environment (NI)

If an existing agency was made responsible for implementation, its former focus was on buildings, energy, or another area:

Buildings

17. TRAINING \& EDUCATION provided for architects, engineers and other professionals:

Written guidelines to assist with compliance procedure

Example calculations

Seminars, workshops, or conferences

18. Compliance mechanisms used at different stages in construction process:

a. PRIOR to construction:

Certification/approval

Percent designs checked: 100

Comment

e. Effectiveness of combined compliance mechanisms (scale of 1-5): 5

f. Explanation for effectiveness in part e: Plans for every building are checked/approved. Everyone [is] aware of construction inspections and final inspections. Plus powers to force

19. Types of assessments or audits of energy standards' impact:

a. ENERGY SAVINGS POTENTIAL based on prototypical (not actual) buildings:

Completed

b. MEASUREMENTS OF ENERGY SAVNGS in actual buildings complying with standard:

In progress

c. COST EFFECTIVENESS based on engineering economic CALCULATIONS:

Completed

d. COST EFFECTIVENESS based ON ACTUAL COSTS:

In progress

e. Other Assessments: - None
C. AFTER construction:

Certification/approval

Percent buildings checked: 95

Comment

Objective is inspection of every building on completion.

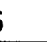
some stage; many checked frequently.

Percent sites checked: 75

Most buildings checked at

\section{d. Other compliance procedures - None}




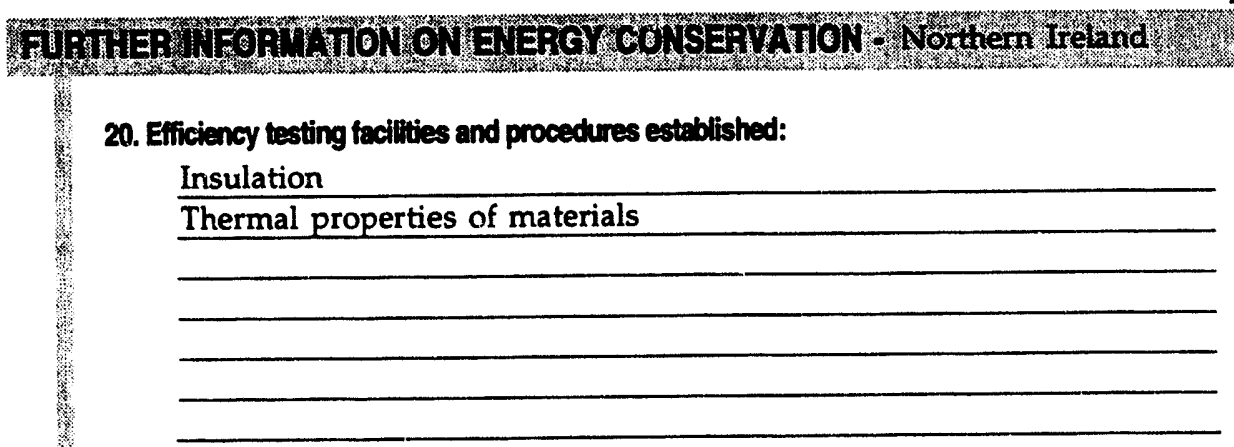

21. Other programs or policies developed to increase energy efficiency in buildings:

Information programs

$\overline{-}$

Comment Energy awareness campaigns-Department of Economic Development, Energy Efficiency Service

Additional sources of information about energy efficiency for buildings in: Northern Ireland

1. Department of the Environment, Approved Document $L$

2. BREDEM-Domestic Energy Model

3. CIBSE Building Energy Code, Part 2.

22. Contect for written copy of energy standard specified in Question 4:

Name

Address: HMSO Bookshop

80 Chichester St.

Belfast, BTI 4JY

Country: Northern Ireland

Tel: $\quad 44-323-238451$

Fax:

Types of supporting information available:

Buillding Amendment regulations (N.I) 1991, Technical Booklet E, Conservation of Fuel and Power

Other energy standards for non-residential buildings:

Sunvey completed by: David L. Stew art

Title: Principal Architect

Department of the Environment for Northern Ireland

Cawood House, 24/26 Arthur St.

Belfast, BT 14 GP

Country: Northern Ireland

Tel: $\quad 44232246898$

Fax 44232233575

Date completed: $\quad 3 / 13 / 92$ 


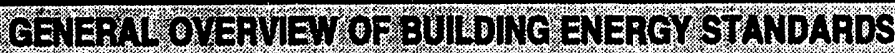

1. General building standards exist at the following govemmental levels:

National

2. Proposed or existing ENERGY standards cover the following building sectors: Both Residential and Non-Residential

3. Status of NonResidential Building Energy Standards at the:
a National level:
Mandatory
b. Regional level:

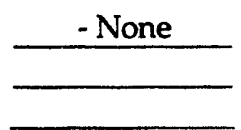
G. Locail level:
- None

\section{Single energy standard selected for further description:}

Title, Organization: "Thermal Insulation and Air Imperviousness" (Chapter 53 af the Norwegian BuildingRegulations)

Year: 1987

Ceographic Coverage: Nation

Abbreviated Title: NBR-53-87

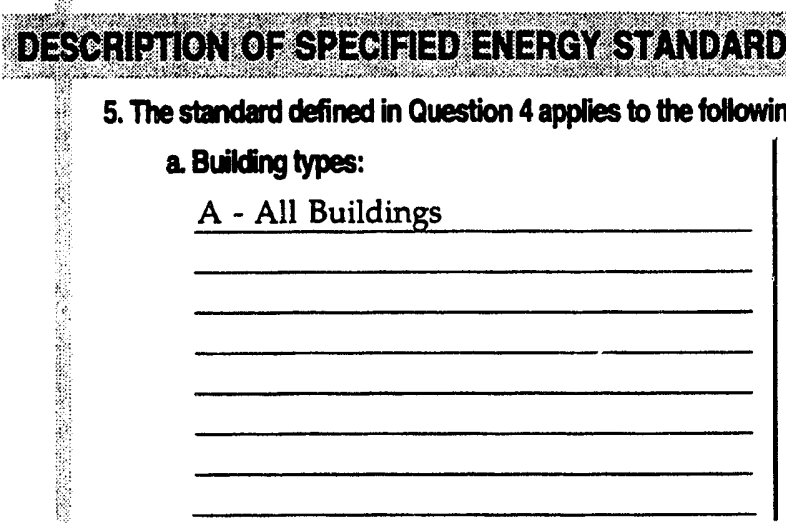

6. Basic approach of the standard: Both prescriptive and performance

7. The following subjects are included in the energy standard:

a. Whole builing energy provisions:

- None

c. Lighting provisions:

- None

e. Other provisions:

- None b. Building emelope provisions:

Roof

Wall system

Fenestration system

Infiltration

\section{d. Mechanical provisions:}

Air/Water distribution efficiency

$\overline{ }-\overline{ }$ 


\section{Organizations involved in developing the standard:}

Government agency: National Office of Building Technology and Administration

Research Group: SINTEF

Government agency: Ministry of Petroleum and Energy

Industry group: Representatives of private companies/businesses

9. Decision Process: Mandate

10. Information used in developing the standard:

a. PHYSICAL CHARACTERISTICS of existing buildings

Gathered through audits and surveys

\section{WEATHER data}

Gathered through measurements

11. Standards from a different country used as source material:

Denmark

Sweden

Finland
Comment: National Office of Building Technology and Administration/Ministry of Local Government

12. COMPUTER programs used:

a In developing the standard: Yes

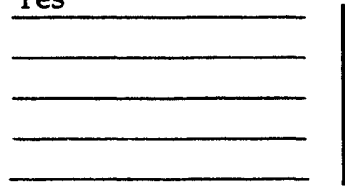

b. ENERGY USE of existing buildings:

Computer simulations used for estimates

\section{d. Other information}

-None

b. For complying with the standard: ?

13. Standard is set at a level: Equal to current practice

14. Considerations influencing the inclusion or exclusion of measures in the standard:

E - Cost effectiveness

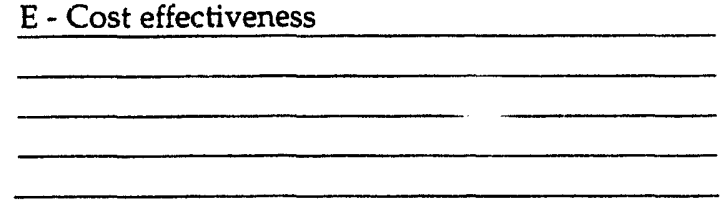

Comments:

\section{5a. Standard scheduled for regular review and revision?}

Yes: every fifth year. There is currently underway a new building code. It is scheduled to be launched in 1993.

\section{b. Does revision include procedures to MONTOR and EVALUATE earlier versions of the standard?}

Yes: several surveys are undertaken in this respect as fundamental to developing new building codes.

$$
\text { C }-83
$$


16. Entities involved in IMPLEMENTING energy standards:

Existing agency: National Office of Building Technology and Administration

If an existing agency was made responsible for implementation, its former focus was on buildings, energy, or another area:

Other: general building codes

17. TRAINING \& EDUCATION provided for architects, engineers and other professionals:

Written guidelines to assist with compliance procedure

Example calculations

18. Compliance mechanisms used at different stages in construction process:

a. PRIOR to construction:

Certification/approval

Percent designs checked: 100

Comment:

All designs are checked at local level. But the qua' ity of the check is not $100 \%$. The b. DURING construction:

?

Percent sites checked: ?

Comment:

Uncertain whether onsite inspections are undertaken.
C. AFTER construction:

Certification/approval

Percent buldings checked: ? Comment

d. Other compliance procedures - None

e. Effectiveness of combined compliance mechanisms (scale of 1-5):

f. Explanation for effectiveness in part e: Problems with personnel qualifications. As mentioned above, system is under revision.

19. Types of assessments or audits of energy standards' impact:

a. ENERGY SAVNGS POTENTIAL based on prototypical (not actual) buildings:

Completed: Noregian consulting firm Energidata a/s has conducted several surveys of energy savings

b. MEASUREMENTS OF ENERGY SAVNGS in actual buildings complying with standard:

Completed: Surveys have been undertaken by the research institution NBI.

c. COST EFFECTIVENESS based on engineering economic CALCULATIONS:

Completed: Ref. Energidata a/s

d. COST EFFECTIVENESS based On ACTUAL COSTS:

Completed: Ref. NBI and Energidata a/s

e. Other Assessments: - None 
20. Efficiency testing facilities and procedures established:

Unsure

21. Other programs or policies developed to increase energy efliciency in buildings:

Information programs

Rebates
Comment Focus on increasing efficiency in existing buildings.

\section{Additional sources of information about energy efficiency for buildirgs in: Norway}

1. The Ministry of Petroleum and Energy. "Energy Economizing and Energy Research," Report No. 61 to the Norwegian Storting (1988-89)

2.

3.

22. Contact for written copy of energy standard specified in Question 4:

Name

Address:

Country:

Tel:

Fax:

Types of supporting information available:

Other energy standards for non-residential buildings:

\section{Survey completed by:}

Title: Ministry of Petroleum and Energy

P.O. Box 8148 Dep.

Riso National Library, P.O. Box 49

N- 0033 Oslo 1

Rosklide Country: Norway

Tel: $\quad 472346341 \quad$ Fax: 472349568

Date completed: $\quad 4 / 24 / 92$ 


\section{GENERML OVERVIEW OF BUILDING ENERGY STANDARDS}

1. General building standards exist at the following govemmental levels:

National

Regional

Local

2. Proposed or existing ENERGY standards cover the following building sectors: Both Residential and Non-Residential

3. Status of Non-Residential Building Energy Standards at the:

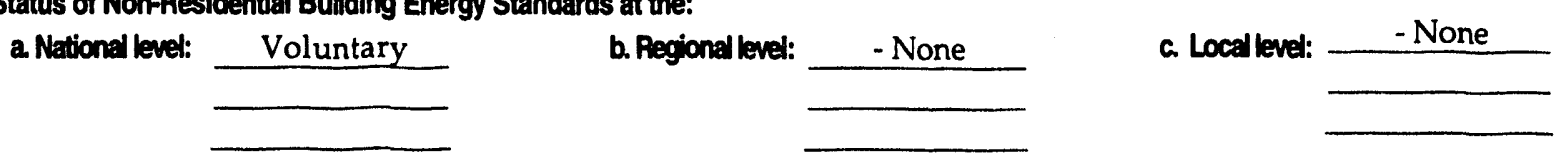

4. Single energy standard selected for further description:

Titte, Organization: Building Energy Code of Pakistan. ENERCON, Environment and Urban Affairs Division

Year: 1990 Ceographic Coverage: Nation Abbreviated Title: BEC, 1990

DESCAIPTION OF SPECIFIED ENERGY STANDARDS - BEC, 1990

5. The standard defined in Question 4 applies to the following kinds of buildings:

a. Building types:

O - Offices

H -Hotels / Hospitals/ Schools

G - Government Facilities

$\mathrm{S}$ - Single-family residential

F - Restaurants

C - Commercial/retail stores

6. Basic approach of the standard: Both prescriptive and performance

7. The following subjects are included in the energy standard:

a Whole buiding energy provisions:

E- Energy amount target

E

c. Lighting provisions:

Control requirements

Other: Daylighting

e. Other provisions:

Yes: Thermostat settings

\section{Other: Daylighting}

b. Building vintage:

New buildings

c. Other characteristics:

Other: permanent buildings/human habitation

$\longrightarrow$

b. Building envelope provisions:

Roof

Wall system

Fenestration system

Infiltration

\section{d. Mechanical provisions:}

Air/Water distribution efficiency

Load Calculations for equipment sizing

Controls

Ventilation

Equipment efficiency 


\section{Organizations involved in developing the standard:}

Government agency: Environment and Urban Affairs Division

Government agency: Pakistan Public Works Department

9. Decision Process: Consensus

Comment:

10. Information used in developing the standand:

a. PHYSICAL CHARACTERISTICS of existing buildings

Estimated using professional judgment

\section{c. WEATHER data}

Already available prior to standard

11. Standards from a different country used as source material:

US: California Title 24

US: ASHRAE

\section{b. ENERGY USE of existing buildings:}

Computer simulations used for estimates

\section{d. Other information}

-None

12. COMPUTER programs used:

a. In developing the standard:

- None

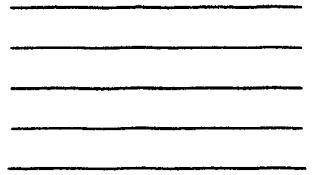

b. For complying with the standard: Uncertain

$\overline{ }$

13. Standard is set at a level: Above current practice

14. Considerations influencing the inclusion or exclusion of measures in the standard:

E - Cost effectiveness

Availability of energy efficient products

Similarity/difference to local design

Comfort
Comments:

The basic aim was to produce a code which can be compiled using local expertise, materials, and technology

\section{5a. Standard scheduled for regular review and revision?}

Yes: once every 5 years by a committee of persons from ENERCON and the Environment and Urban Affairs Division.

\section{b. Does revision include procedures to MONTTOR and EVALUATE earlier versions of the standard?}

No 
16. Entities involved in MPLEMENTING energy standards:

Existing agency: ENERCON

If an existing agency was made responsible for implementation, its former focus was on buildings, energy, or another area:

Other: energy efficiency

17. TRANING \& EDUCATION provided for architects, engineers and other professionals:

Written guidelines to assist with compliance procedure

Example calculations

Compliance forms

Seminars, workshops, or conferences

18. Compliance mechanisms used at different stages in construction process:

a. PRIOR to construction:

No mechanism

Percent designs checked: -

Comment:

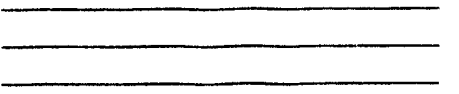

b. DURING construction:

No mechanism

Percent sites checked: -

Comment:

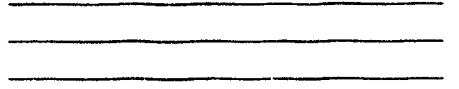

c. AFTER construction:

No mechanism

Percent buildings checked:

Comment:

d. Other compliance procedures - None

e. Effectiveness of combined compliance mechanisms (scale of 1-5):

1. Explanation for effectiveness in part e:

19. Types of assessments or audits of energy standards' impact:

a. ENERGY SAVNGS ?OTENTIAL based on prototypical (not actual) buildings:

Completed

b. MEASUREMENTS OF ENERGY SAVNGS in actual buildings complying with standard:

Planned

c. COST EFFECTIVENESS based on engineering economic CALCULATIONS:

In progress

d. COST EFFECTIVENESS based on ACTUAL COSTS:

Planned

e. Other Assessments: None conducted 
20. Efficiency testing facilities and procedures established:

Motors

Ballasts

Fixtures

21. Other programs or policies developed to increese energy efficiency in buildings:

Audits (free or subsidized)

Information programs

Building energy standards
Comment Described in "Building Sector Energy Conservation Programme of Pakistan," Eneroy and Buildings, 15-16 (1990/91):533-535.

\section{Additional sources of information about energy efficiency for buildings in: Pakistan}

1. Jamy, Gul Najam. 1990. "The Evolution and Euture Direction of a Comprehensive Building Energy Conservation Programme for Pakistan." 2nd IntlEnergy Conservation Symposium, Karachi--Pakistan.

2. Arshad, M.K et al 1990 "The Building Energy Code of Pakistan," presented at 2nd Intl Energy Conservation Symposium, Karachi--Pakistan

3. Cunningham, Gregory W. and Jamil Masud. 1990 "Building Energy Simulation:Computer Modelling of Buildings in Pakistan," presented at 2nd Intl Energy Conservation Symposium, Karachi-_Pakistan.

22. Contact for written copy of energy standard specified in Question 4:

Nome Gul Najam Jamy

Address: Deputy Chief (Buildings)

ENERCON, Buland Markaz

33-Blue Area

Islamabad

Country: Pakistan

Tel: $\quad 92813003 / 813009$

Fax: $\quad 92826212$

Types of supporting information available:

Code compliance handbook, axailable from ENERCON

Other energy standards for non-residential buildings:

-None

Survey completed by: Gul Najam Jamy

Title: Deputy Chief (Buildings)

ENERCON

Buland Markaz, 33, Blue Area

Islamabad

Country: Pakistan

Tel: $\quad 92813003$

Fax: 92826212

Date completed: $\quad 3 / 8 / 92$ 
1. Ceneral building standards exist at the following governmental levels:

\author{
National
}

2. Proposed or existing ENERGY standards cover the following building sectors: Non-Residential Only

3. Status of Non-Residential Bullding Energy Standards at the:
a National level:

\begin{tabular}{c} 
Voluntary \\
\hline Proposed \\
\hline
\end{tabular}
b. Regional level:

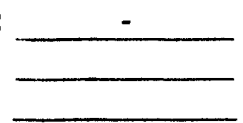
a. Locel level:

\title{
4. Single energy standard selected for further description:
}

Tithe, Organization: Proposed Building Energy Use Standards, Office of Energy Affairs

Year: $198 ?$

Geographic Coverage: Nation

Abbreviated Title: BEUS-OEA

\section{DESCRIPTION OF SPECIFIED ENERGV STANDARDS - BEUS-OEA}

5. The standard defined in Question 4 applies to the following kinds of buildings:

a. Building types:

O - Offices

H - Hotels

G - Government Facilities

C - Commercial/retail stores

D - Hospitals/ schools

F - Restaurants b. Building vintage:

Both new and existing

c. Other characteristics:

E - Amount of energy: Energy usage of more than 10W/sq.m

6. Basic approach of the standard: Both prescriptive and performance

\section{The following subjects are included in the energy standard:}

a Whole buiding energy provisions:

P-Peak electricity demand

\section{c. Lighting provisions:}

Control requirements

Power density

Illumination requirements

e. Other provisions:

\section{b. Buiging envelope provisions:}

Roof

Wall system

Fenestration system

Infiltration

d. Nechanical nrovisions:

Air/Water distribution efficiency

Load Calculations for equipment sizing

Controls

Ventilation

Equipment efficiency

-None 


\section{Organizations involved in developing the standard:}

Government agency: Office of Energy Affairs; Philippine Council for Industry and Energy Research and

Academic institution: University of Philippines

Foreign development agency: U.S. Agency for International Development; Lawrence Berkeley Laboratory

Other: technical Committee composed of building experts and practitioners

\section{Decision Process: Consensus}

Comment:

10. Information used in developing the standard:

a. PHYSICAL CHARACTERISTICS of existing iuildings

Gathered through audits and surveys

\section{c. WEATHER dato}

Gathered through measurements

11. Standards from a different country used as source material:

Thailand:

\section{b. ENERGY USE of existing buildings:}

Gathered through audits and surveys

\section{d. Other information}

-None

b. For complying with the standard: No

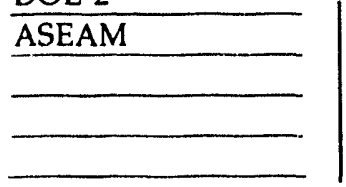

12. COMPUTER programs used:

a. In developing the standard:

$\underline{\text { DOE-2 }}$

13. Standard is set at a level: Equal to current practice

14. Considerations influencing the inclusion or exclusion of measures in the standard:

E - Cost effectiveness

Availability of energy efficient products

Similarity/difference to local design

Comfort
Comments:

15a. Standard scheduled for regular review and revision?

Yes

b. Does revision include procedures to MONITOR and EVALUATE earlier versions of the standard?

Yes 
$26-0$

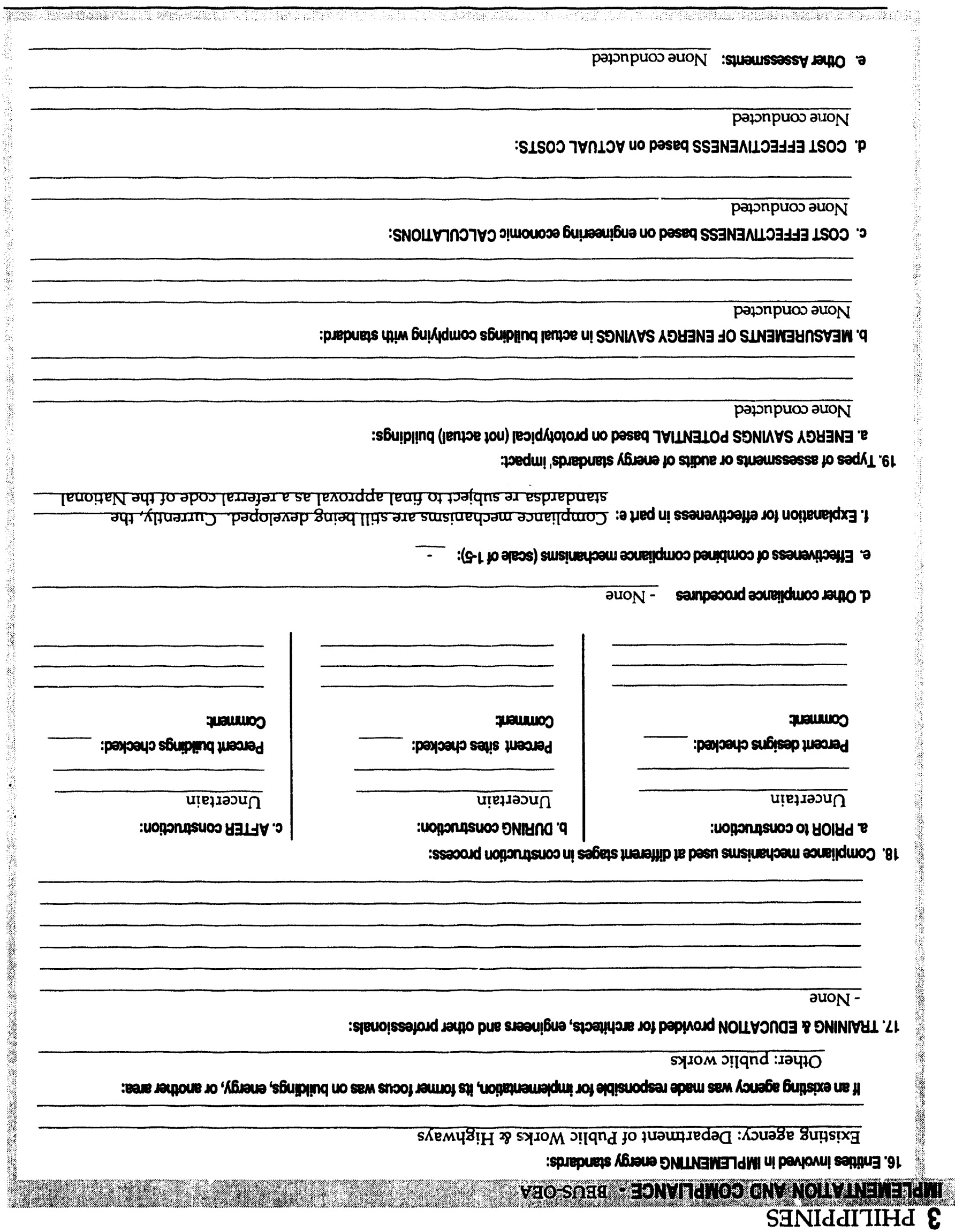




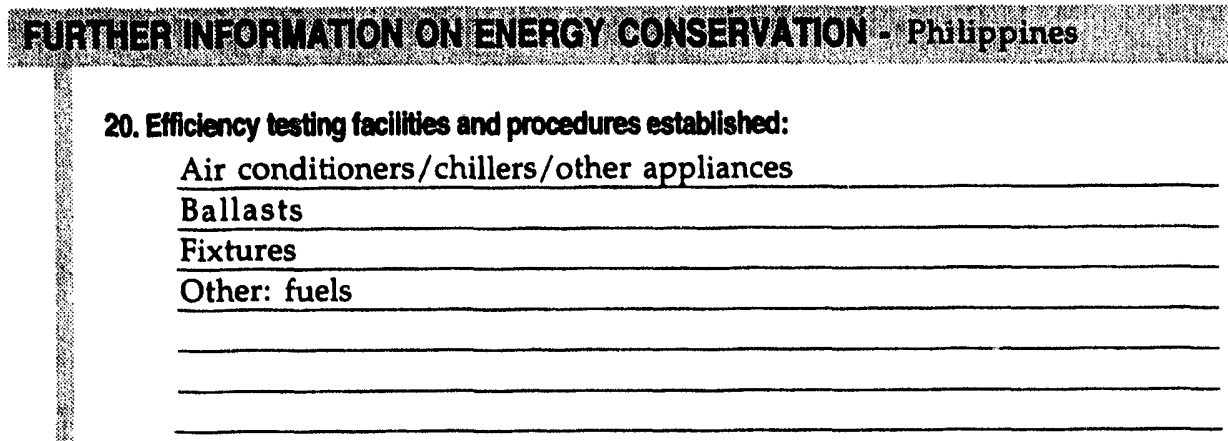

21. Other programs or pollicies developed to increase energy efficiency in buildings:

Information programs

Audits (free or subsidized)

Rebates
Comment: Office of Energy Affairs; Philippine Council for Industry and Energy Research and Dexelopment; University of Philippines; National Engineering Center

Additional sources of information about energy efficiency for buildings in: Philippines

1.

2.

3.

22. Contact for written copy of energy standard specified in Question 4:

Name: Charisse B. Tablante

Address: Office of Energy Affairs

Merrit Road, Fort Bonifacio

Makati, Metro Manila

Country: Philippines

Tel: $\quad 632877633$

Fax: $\quad 632877633$

Types of supporting information available:

$=$

Other energy standards for non-residential buildings:

None

Survey completed by:

Charisse B. Tablante

Title: Chief, Conservation Division

Office of Energy Affairs; Office of the President

Merritt Rd., Fort Bonifacio

Makati, Metro Manila

Country: The Philippines

Tel: $\quad 63-2-877-633$

Fax: $63-2-817-8603$

Date completed: $\quad 4 / 2 / 92$ 


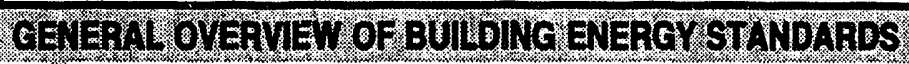

1. General bullding standards exist at the following governmental levels:

National

2. Proposed or existing ENERGY standards cover the following building sectors: Both Residential and Non-Residential

3. Status of Non-Residential Building Energy Standards at the:
a National havel:
Mandatory
b. Regional level:
- None
a. Local level:
- None

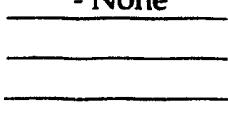

\section{Single energy standard selected for further description:}

Title, Organization: PN-91/B-02020. Polish Committee for Standardization, Measures, and Quality Control

Year: 1991 Geographic Coverage: Nation Abbreviated Titte: PN-91/B-02020

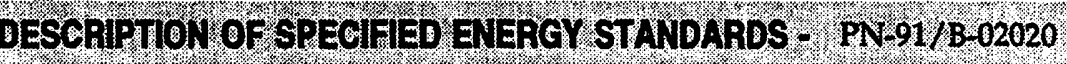

\section{The standard defined in Question 4 applies to the following linds of buildings:}

\section{a. Building types:}

A - All Buildings b. Building vintage:

Both new and existing

c. Other characteristics:

P - Physical size

A - Air-Conditioned

6. Basic approuch of the standard: Performance-based

7. The following subjects are included in the energy standard:

a. Whole building energy provisions:

E- Energy amount target

c. Lighting provisions:

?

e. Other provisions:

-None b. Buiding envelope provisions:

Roof

Wall system

Fenestration system

Infiltration

Other: Percent of setting humidity in walls

d. Mechanical provisions:

?

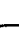




\section{Organizetions involved in developing the standerd:}

Government agency: PKNMIJ

Research group: Institute of Building Technique

9. Decision Proces: ?

Comment:

10. Information used in developing the standard:

\section{a. PHYSICAL CHARACTERISTICS of existing buildings}

Already available prior to standard

\section{WEATHER data}

Already available prior to standard

11. Standards from a tifferent country used as source material:

Yes

\section{b. ENERGY USE of existing buildings:}

?

$\overline{-}$

\section{d. Other information}

-None
12. COMPUTER progrems used:

a In developing the standard:

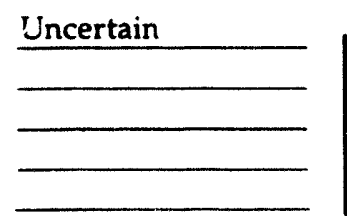

b. For complying with the standard: ?

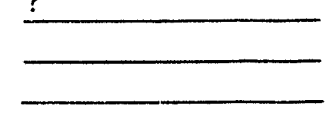

13. Standard is set at a level: Lower than current practice

14. Considerations influencing the inctusion or exchusion of meesures in the standard:

E - Cost effectiveness

A - Availability of energy efficient products

S - Similarity/difference to local design

C-Comfort

15a. Standard scheduled for regular review and revision?
Comments:

b. Does revision inctuce procecures to MONTOR and EVALUATE earlier versions of the standard?

Yes:Standards PN-91/B 02020 is compulsory and PN-82/B-02020 was compulsory too 
16. Entities involved in IMPLEMENTNG energy standards:

Existing agency: PKNMIJ

If an existing agency was made responsible for implementation, its former focus was on buildings, energy, or another area:

?

17. TRANING \& EDUCATION provided for architects, engineers and other professionals:

Written guidelines to assist with compliance procedure

Example calculations

Information or resource center

18. Compliance mechanisms used at different stages in construction process:

a. PRIOR to construction:

?

Percent designs checked: ?

Comment

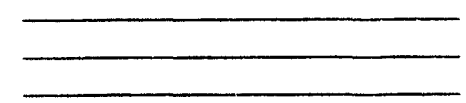

b. DURWG construction:

?

Percent sites checked: ?

Comment:

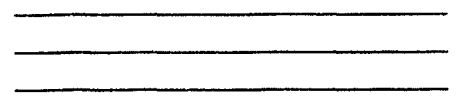

C. AFTER construction:

?

Percent buildings checked: ?

Comment

d. Other compliance procedures - None

e. Effectiveness of combined compliance mechanisms (scale of 1-5): ?

f. Explanation for effectiveness in part e: ?

19. Types of assessments or audits of energy standards' impact:

a. ENERGY SAVINGS POTENTIAL based on prototypical (not actual) buildings:

Completed

b. MEASUREMENTS OF ENERGY SAVNGS in actual buildings complying with standard:

Planued

c. COST EFFECTIVENESS based on engineering economic CALCULATIONS:

?

d. COST EFFECTIVENESS based On ACTUAL COSTS:

e Other Assessments: ? 


\section{FURTHER NFORMATION ON ENERGY CONSERVATION - Poland}

\section{Efficiency testing facilities and procedures established:}

Insulation

Ballasts

Thermal properties of materials

21. Other programs or policies developed to increase energy efficiency in buildings:

?

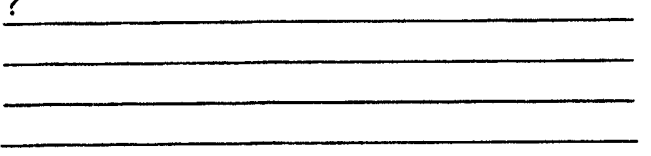

Comment

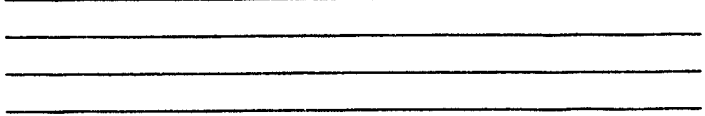

Additional sources of information about energy efficiency for buildings in: Poland

1.

2.

3.

22. Contact for written copy of energy standard specified in Question 4:

Name:

Address: PKNMiJ, Foreigh Relations Department

ul. Electoralna 2

00-950 Warsawa

Country: Poland

Tel: $\quad 4822205434$

Fax: $\quad 4822208378$

Types of supporting information available:

Other energy standards for non-residential buildings:

Survey completed by: Roland Izbicki

Title: Polski Komitet Normalizacyjny (PKNIJ)

Building Department

ul. Swietokrzyska 14b

Warszawa

Country: Poland

Tel: $\quad 4822267475$

Fax: 4822274113

Date completed: $\quad 7 / 22 / 92$ 


\section{GENERTI OVEAVEW OF BUILDING ENERGY STANDARDS}

1. General building standards exist at the following govemmental levels:

National

2. Proposed or existing ENERGY standards cover the following building sectors: Both Residential and Non-Residential

3. Status of Non-Residential Building Energy Standards at the:
a National level:
Mandatory
b. Regional leve.

G. Locel level:

$\longrightarrow$

4. Single energy standard selected for further description:

Titte, Organization: CSOPT

Year:

Geographic Coverage: Nation

Abbreviated Title: CSOPT-91

\section{DESCAIPTION OF SPECIFIED ENERGY STANDARDS - CSOPT-91}

5. The standard defined in Question 4 applies to the following kinds of buildings:

a. Building types:

A - All Buildings

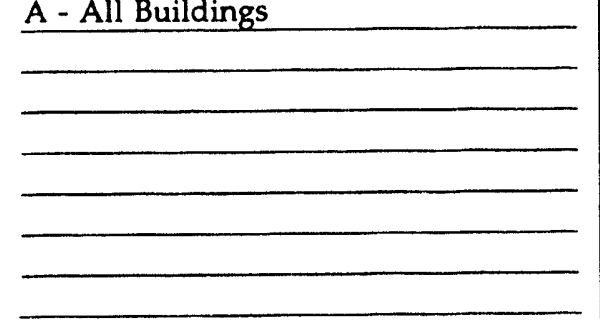

b. Building vintage:

Both new and existing

c. Other characteristics:

Other: Limiting nominal thermal loads (winter and summer conditions)

6. Basic approach of the standard: Both prescriptive and performance

7. The following subjects are included in the energy standard:

a Whole building energy provisions:

E- Energy amount target

\section{c. Lighting provisions:}

Other: power density used for calculation only

e. Other provisions:

-None

\section{b. Büling envelope provisions:}

Roof

Wall system

Fenestration system

Infiltration

\section{d. Mechenical provisions:}

- None: covered in another standard 


\section{STANDARDS DEVELOPMENT PROCESS - CSOPT-91}

8. Organizations involved in developing the standard:

Government agency: CSOPT (Lisbon)

Government agency: DGE (Lisbon)

Academic institution: FUEP (Porto)

Academic institution: IST (Lisbon)

9. Decision Process: Consensus

Comment Majority decision, no consensus reached for final version. Organizations included:AIP, LNEC, AECOPS

10. Information used in developing the standard:

a. PHYSICAL CHARACTERISTICS of existing buildings

Already available prior to standard

\section{c. WEATHER data}

Already available prior to standard

11. Standards from a different country used as source material:

France (moderate extent)

Spain

\section{b. ENERGY USE of existing buildings:}

Estimated using professional judgment

\section{d. Other information}

-None

\section{COMPUTER programs used:}

a In developing the standard: - None

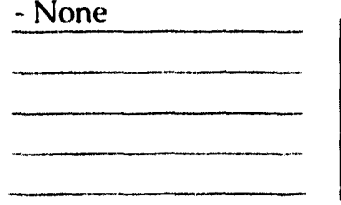

b. For complying with the standard: Uncertain

13. Standard is set at a level: Equal to current practice

\section{Considerations influencing the inclusion or exclusion of measures in the standard:}

Similarity/difference to local design

15a. Standard scheduled for regular review and revision?

No

b. Does revision include procedures to MONTOR and EVALUATE earlier versions of the standard?
Comments:

Pressure from AECOPS (the Building Constructors' Association) not to set the standard to a level above current practice. 


\section{PORTUGAL}

\section{ILPLEEMENTATION ANO COMPLANCE - CSOPT-91}

16. Entities involved in IMPLEMENTING energy standards:

Existing agency: Cons. Sup. Obras Pub. Tranp.

If an existing agency was made responsible for implementation, its former focus was on buildings, energy, or another area:

Other: general

17. TRAINING \& EDUCATION provided for architects, engincers and other professionals:

Written guidelines to assist with compliance procedure

Example calculations

Compliance forms

Seminars, workshops, or conferences

18. Compliance mechanisms used at different stages in construction process:

a. PRIOR to construction:

Certification/approval

Percent designs checked: ?

Comment:

Major localauthorities enforce approval; smaller local authorities unable to enforce

\section{b. DURING construction:}

No mechanism

Percent sites checked: high comment

Checks for compliance of other standards, but not for one under discussion
C. AFTER construction:

No mechanism

Percent buildings checked: high Comment:

Checks for compliance of other standards, but not for one under discussion.

\section{d. Other compliance procedures}

e. Effectiveness of combined compliance mechanisms (scale of 1.5): 3.5

f. Explanation for effectiveness in part e: Compliance is most effective in large urban: areas and there are a few problems (mainly bureaucratic) in applying the standard to smaller towns

19. Types of assessments or audits of energy standards' impact:

a. ENERGY SAVINGS POTENTIAL based on prototypical (not actual) buildings:

Completed: for solar houses made by FEUP/LNETI in the region of Porto

b. MEASUREMENTS OF ENERGY SAVNGS in actual buildings complying with standard:

Planned: this type of work is carried out by universities

c. COST EFFECTIVENESS based on engineering economic CALCULATIONS:

Planned: this type of work is carried out by universities

d. COST EFFECTIVENESS based on ACTUAL COSTS:

None conducted

e. Other Assessments: Planned: 1992 national survey sponsored by DGE 


\section{FURTHEA INFORMATION ON ENERGY CONSERVATION - POTtugal}

20. Efficiency testing facilities and procedures established:

Motors

Insulation

Air conditioners/chillers/other appliances

Fixtures

Thermal properties of materials

Other: refrigeration equipment (tests available only for low or moderate power

\section{Other programs or policies developed to increase energy efficiency in buildings:}

Information programs

Information programs

Comment General public information (eleciricity use, heat losses in buildings);

Subsidized solar thermal panels (program terminated)

\section{Additional sources of information about energy efficiency for buildings in: Portugal}

1. A energia em Portugal-DGEMin. Industria e Energia (information on the energy situation in Portugal)

2. Series of properties of building materials - thermal properties, physical properties of most common masonry solutions used in Portugal- LNEC Laboratório Nacional de Engenharia Civil

3. The Portuguese information is seldom sperific for buildings. Usually it considers different sectors (industry in particular). All titles refer to Portugues language publications

\section{Contact for written copy of energy standard specified in Questior}

\section{Name}

Address:

Conselho Superior de Obras Públicas e Transportes (CSOPT)

R.S. Mamede ao Caldas

1196 Lisboa Codex

Country: Portugal

Tel: $\quad 351-1-8884234$

Fax: $\quad 351-1-876430$

Types of supporting information available:

Program disk: Oliveria Fernandes; FEUP - Univ do Porto; R dos Bragas; 4099 Porto Codex; Portugal. Tel: $351-2-311-254 ;$ Fax: $351-2-319-280$

Other energy standards for non-residential buildings:

Yes: Reg. da Qualidade do Sist. de Climatizacao em Edificios; CSOPT

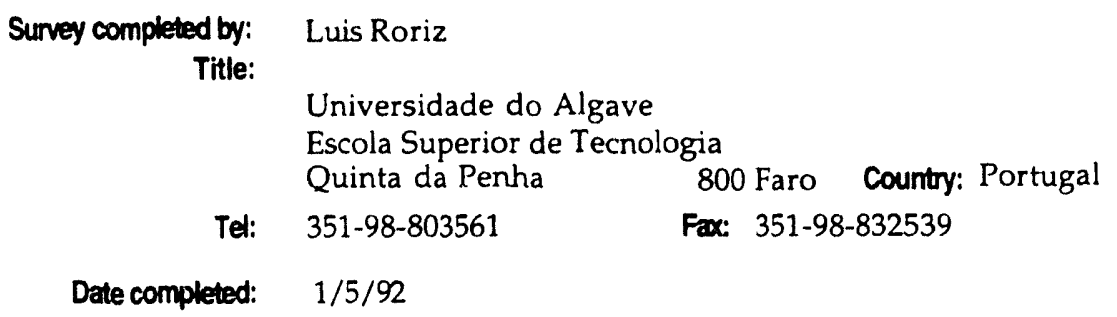




\section{GENERAL OVERVIEW OF BUILOING ENERCY STANDARDS}

1. General bullding standards exist at the following govemmental levels:

$$
\text { National }
$$

Regional

Local

2. Proposed or existing ENERGY standards cover the following building sectors: Both Residential and Non-Residential

3. Status of Non-Residential Building Energy Standards at the:
a Netional level:
Voluntary
b. Regional level:

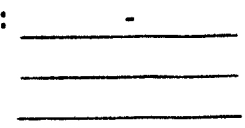

a. Local level:

4. Single energy standard selected for further description:

Title, Organization: Building regulations, Romania

Year: ? Ceographic Coverage: Nation Abbreviated Title: BR-Romania

\section{DESCRIPTON OF SPECIFED ENERCY STANDARDS - BR-Romania}

5. The standard defined in Question 4 applies to the following kinds of buildings:

\section{a. Building types:}

A - All Buildings
6. Basic approach of the standard: Prescriptive

7. The following subjects are included in the energy standard:

a Whole building energy provisions:

E- Energy amount target

c. Lighting provisions:

- None

e. Other provisions:

-None

b. Building vintage:

Both new and existing

c. Other characteristics:

P - Physical size

E - Amount of energy

\section{b. Building envelope provisions:}

Yes

d. Mechanical provisions:

$\stackrel{?}{?}$

$\stackrel{?}{2}$

e. Other provisions:
-None
C- 102




\section{Organbations involved in developing the standard:}

Government agency

Research group

Industry group

9. Dectelon Proces: Mandate

Comment:

10. Information used in developing the standard:

a. PHYSICAL CHARACTERISTICS of existing buildings

Estimated using professional judgment

c. WEATHER dato

Gathered through measurements

11. Standards from a different country used as source material:

European countries

\section{b. ENERGY USE of existing buildings:}

Estimated using professional judgment

Gathered through audits and surveys

\section{d. Other information}

-None

12. COMPUTER prograns used:

a. In developing the standard: Uncertain

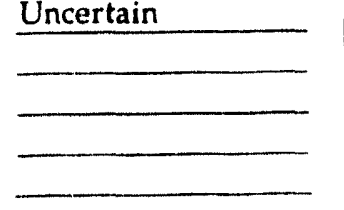

b. For complying with the standard: ?

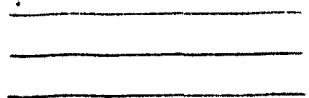

13. Standard is set at a level: Equal to current practice

14. Considerations influencing the inclusion or exclusion of measures in the standard:

E - Cost effectiveness

Availability of energy efficient products

Similarity/difference to local design

15a. Standard scheduled for regular review and revision?

Yes: under current revision and update

b. Does revision include procedures to MONITOR and EVALUATE earlier versions of the standand?

Unsure
Comments:

$+$


18. Compliance mechanisms used at different stages in construction process:

a PRIOR to construction:

Penalty

Percent designs checked: ?

Comment:

Difficult to estimate.

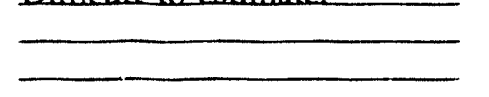

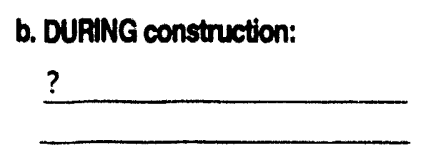

Percent sites checked: Comment:

Difficult to estimate

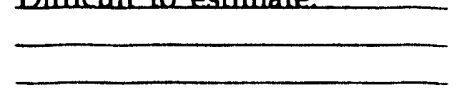

C. AfTER construction:
Percent buildings checked:
Comment
Difficult to estimate.

d. Other compliance procedures - None

e. Effectiveness of combined compliance mechanisms (scale of 1-5): 2

1. Explanation for effectiveness in part e:

19. Types of assessments or audits of energy standards' impact:

a. ENERGY SAVINGS POTENTIAL based on protolypical (not actual) buildings:

In progress

b. MEASUREMENTS OF ENERGY SAVNGS in actual buildings complying with standard:

In progress

c. COST EFFECTIVENESS based on engineering economic CALCULATIONS:

In progress

d. COST EFFECTIVENESS based ON ACTUAL COSTS:

In progress

e. Other Assessments: In progress 
21. Other programs or policies developed to increase energy efficiency in bullilings:

Information programs

Additional sources of information about energy elficiency for buldings in: Romania

1.

2.

3.

22. Contact for written copy of energy standard specified in Question 4:

Nemex

Address:

Country:

Tel:

Fax:

Types of supporting information avallable:

-None

Other energy standards for non-residential buildings:

- None

Comment

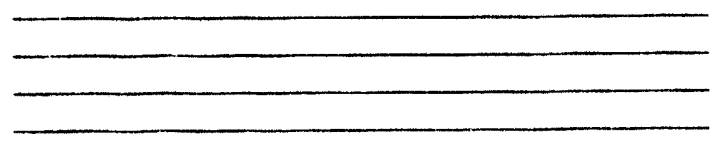




\section{GENERAL OVERVIEY OF BUILDING ENERGY STANDARDS}

1. General bulling standerds exist at the following govemmental levels:

National

2. Proposed or existing ENERGY standends cover the following building sectors: Both Residential and Non-Residential

3. Status of Non-Residential Buliding Energy Standards at the:
a. National lovel:
Mandatory
b. Regional level:
c. Locel level:

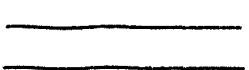

4. Single energy standard selected for further description:

Title, Organization: Building_Regulations, Scotland

Year: ?

$$
\text { Geographic Coverage: Nation }
$$

Abbreviated Title: BR-SCT

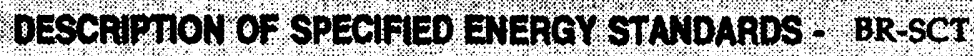

5. The standard defined in Question 4 applies to the following linds of buildings:

\section{a. Building types:}

A - All Buildings b. Building vintage:

New buildings

c. Other characteristics:

- None

6. Basic approach of the standard: Both prescriptive and performance

7. The following subjects are included in the energy standard:

\section{a. Whole buiding energy provisions:}

E- Energy amount target

c. Lighting provisions:

- None

e. Other provisions:

Yes b. Building envelope provisions:

Roof

Wall system

Fenestration system

\section{d. Mecharical provisions:}

Yes 


\section{Organtrations incived in developing the standerd:}

Government agency

Industry group

Academic institution

Research group

9. Decision Process: Mandate

comment:

10. Iftormation used in developing the standard:

a. PHYSICAL CHARACTERISTICS of existing buildings

$$
\text { ? }
$$

C. WEATHER data

?

11. Standands from a different country used as source material:

England and Wales

b. ENERGY USE of existing buildings:

\section{d. Other information}

-None

12. COMPUTER programs used:

a. In developing the standart: Uncertain

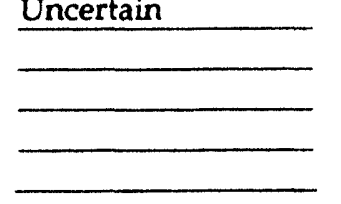

b. For complying with the standand: ?

13. Standard is set at a level: ?

14. Considerations infuencing the inclusion or exclusion of meesures in the standand:

E - Cost effectiveness

Availability of energy efficient products

Similarity/difference to local design

Comfort

15a. Standand schectuled for regular review and revision?

Yes

b. Does revision include procedures to MONITR and EVALUATE carlier versions of the standard?

Yes comments:

$$
\mid
$$




\section{IMPLELENTATION WD COMPLIANCE - BR-SCT}

16. Entities imolved in MMPLEMENTWG energy standands:

Existing agency

If an existing agency was made responsible for implementation, its former focus was on buldings, energy, or another area:

17. TRAINING \& EDUCATION provided for architects, engineers and other professionats:

Written guidelines to assist with compliance procedure

Example calculations

Seminars, workshops, or conferences

18. Compliance mechanisms used at different stages in construction process:

a. PRiOR to construction:

Uncertain

Percent designs checked:

Comment: b. DURING construction:

Uncertain

Percent sites checked:

Comment:

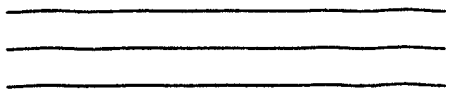

C. AFTER construction:

Uncertain

Percent buildings checked:

Comment:

d. Other compliance procedures -

e. Effectiveness of combined compliance mechenisms (scale of 1-5):

f. Explanation for effectiveness in part e:

19. Types of assessments or aucits of energy standands' impact:

a. ENERGY SAVINGS POTENTAL based on prototypical (not actual) buildings:

b. MEASUREMENTS OF ENERGY SAVINGS in actual buildings complying with standand:

C. COST EFFECTIVENESS besed on engineering economic CALCULATIONS:

d. COST EFFECTIVENESS based on ACTUAL COSTS:

e. Other Assessments:

$$
\text { C - } 108
$$




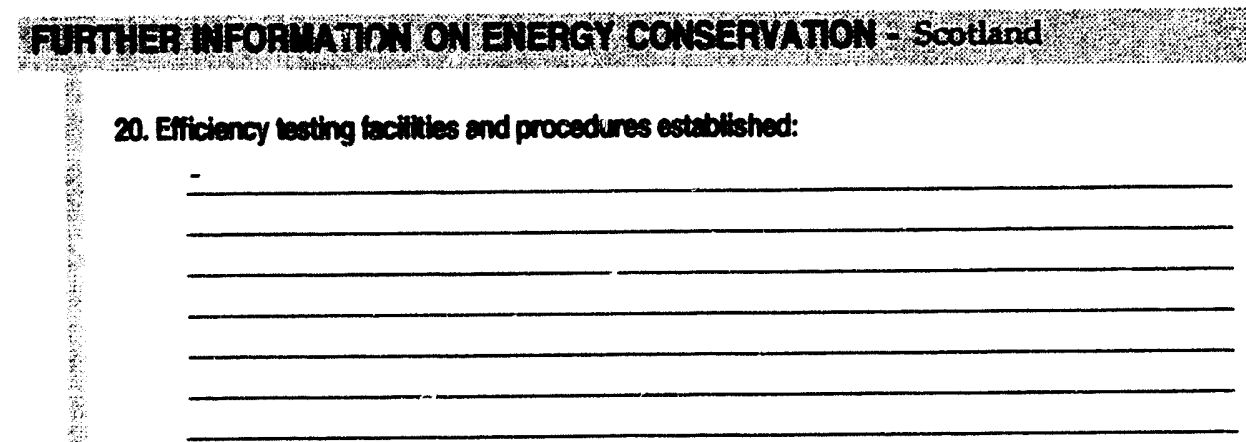

21. Other prograns or policies developed to increase energy eficiency in buildings:

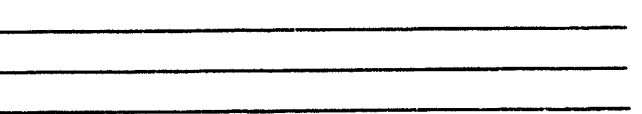

Adritiond sources of informetion about energy elliciency for buildings in: Scotland

1.

2.

3.

22. Contact for witten copy of energy standard specified in Question 4:

Nane

Adtress:

Countr:

Tel:

Fax

Types of supporting information aratable:

Other energy standands for non-residential buildings:

Suncy complated by: John Foster

Thtle: Senior Architect

Building Directorate, Scottish Office

Rm. 3/113 New St. Andrews House

Edinburgh

EH1 3SZ Country: Scotland

Tel: $\quad 44312444782$

Fax not on file, please send

Date compleied: $\quad 3 / 3 / 92$ 


\section{GEXERAL OVERVEY OF BUILBIG ENERGY STANDARDS}

1. Ceneral bulding standards exist at the following govermmental levels:

National

2. Proposed or existing ENERGY standards cover the following building sectors:

Both Residential and Non-Residential

3. Status of NonResidential Building Energy Standards at the:

a National level: Mandatory b. Pegional level:

c. Local leved:

$$
\longrightarrow
$$

4. Single energy standard selected for further description:

Thte, Organization: "Handbook on Energy Conservation in Buildings and Building Services". Singapore Building Control Regulations; Building Control Division, Public Works Department. This Handbook is referred to in Division 10 of the general building code, $S 148 / 89$.

Year: 1980 Geographic Coverage: Nation Abbreviated Title: S 148/89, Div. 10

\section{DESCRIPION OF SPECIFIED ENERGY STANDARDS - S 148/89, Div. 10}

5. The standard deined in Question 4 applies to the following linds of buildings:

a. Bulding types:

A - All Buildings

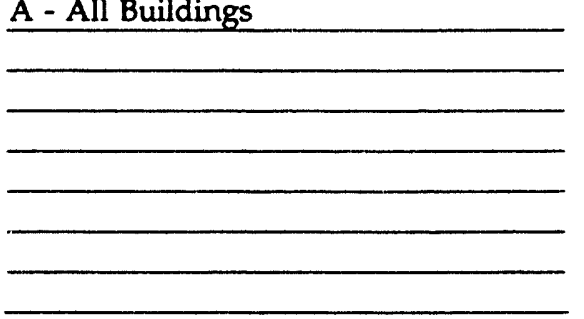

b. Building vintage:

New buildings

c. Other characteristics:

E - Amount of energy: $>30 \mathrm{kw}$ cooling capacity for AC equip.

A - Air-Conditioned

6. Basic approach of the standard: Both prescriptive and performance

7. The following subjects are included in the energy standard:

a Whole buiding energy provisions:

- None

c. Lighting provisions:

Control requirements

Power density

Illumination requirements

\section{e. Other provisions:}

Yes: 1) Eacilities for energy monitering to be profided for all new offices, hotels, and shopping centers; 2) shop units in shopping complex with doors opening directly to the atmosphere to be provided with independent $A / C$ units separate from the building's central air-conditioning system.

\section{b. Builing envelope provisions:}

Roof

Wall system

Fenestration system

Infiltration

\section{d. Mecherical provisions:}

Controls

Ventilation 


\section{STANDARDS DEVELOPUENT PROCESS - S148/89, DiV. 10}

8. Organizations involved in developing the standand:

Government agency: Building Control Division, Public Works Department

Academic institution: National University of Singapore

Government agency: Public Utilities Board

Local interest group: Institution of Engineers

Local interest group: Singapore Institute of Architects

\section{Decision Process: Consensus Comment:}

10. Inionation used in developing the standard:

a. PHYSICAL CHARACTERISTICS of existing buildings

Gathered through audits and surveys

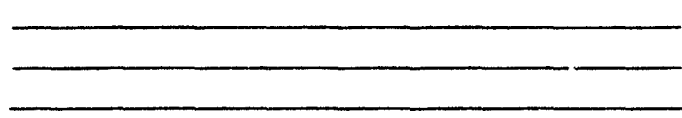

\section{c. WEATHER data}

Gathered through measurements

11. Standards from a different country used as source material:

\section{b. ENERGY USE of existing buildings:}

Estimated using professional judgment

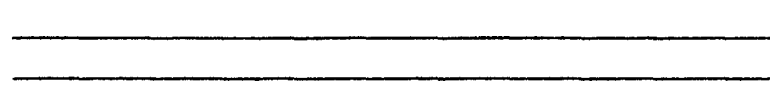

\section{d. Other intormation}

-None

12. COMPUTER programs used:

a. In developing the standard: - None

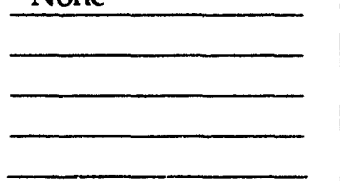

b. For complying with the standard: No

13. Standard is set at a level: Above current practice

\section{Considerations influencing the inclusion or exclusion of measures in the standard:}

E - Cost effectiveness

A - Availability of energy efficient products

$\mathrm{S}$ - Similarity/difference to local design

C-Comfort
Comments:

$\longrightarrow$

\section{5a Standard schectuled for regular review and revision?}

Yes: no fixed schedule. Review is based on feedback from ind ustry as well as from research institution.

b. Does revision include procectures to MONTOR and EVALUATE earlier versions of the standand?

Yes: through feedback from industry 


\section{SINGAPORE}

\section{TPLEMENTATON AND COMPLANCE - S $148 / 89$, Div. 10}

16. Entities involved in MMPLEENTWG energy standards:

Existing agency: Building Control Division

If an existing agency was made responstble for implementation, is former focus was on buldings, energy, or another area:

Buildings

17. TRAINING \& EDUCATON provided for architects, engineers and other professionals:

Written guidelines to assist with compliance procedure

Example calculations

Compliance forms

Seminars, workshops, or conferences

18. Compliance mectanisms used at different stages in construction process:

a. PRIOR to construction:

Certification/approval

Percent designs checked: -

Commert

Random

-

b. DURWG construction:

No mechanism

Percent sites checked: Comment:

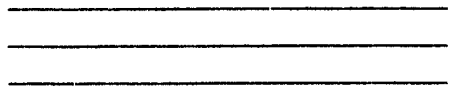

C. AFTER construction:

Certification/approval

Percent buildings checked: Comment:

Random

\section{d. Other compliance procedures}

e. Effectiveness of combined compliance mectarisms (scale of 1-5): 5

f. Explanation for effectiveness in part e: compliance with standard is made a responsibility of the professional

19. Types of assessments or audits of energy standards' impact:

a. ENERGY SAVINGS POTENTIAL based on prototypical (not actual) buildings:

Completed: ASEAN-US cooperative program report

b. MEASUREMENTS OF ENERGY SAVINGS in actual buildings complying with standard: Completed: ASEAN-US cooperative program report

c. COST EFFECTIVENESS based on engineering economic CALCULATIONS:

Completed: ASEAN-US cooperative program report

d. COST EFFECTIVENESS based on ACTUAL COSTS:

Completed: ASEAN Energy Conference Proceedings (1984)

e. Other Assessments: 


\section{Efficiency lesting factlities and procedures established:}

Insulation

Ballasts

Thermal properties of materials

21. Other programs or policies developed to increese energy efficiency in buildings:

Information programs

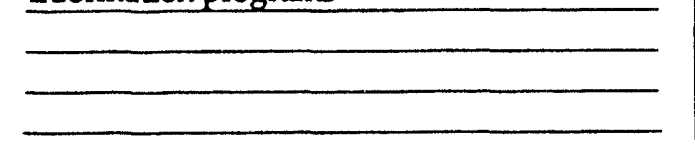

Comment: Public Utilities Board

Additional sources of information about energy efficiency for buildings in: Singapore

1.

2.

3.

22. Contact for written copy of energy standard specitied in Question 4:

Name:

Address:

Country:

Tel: Fax:

Types of supporting information avalable:

Other energy standands for non-residential buildings:

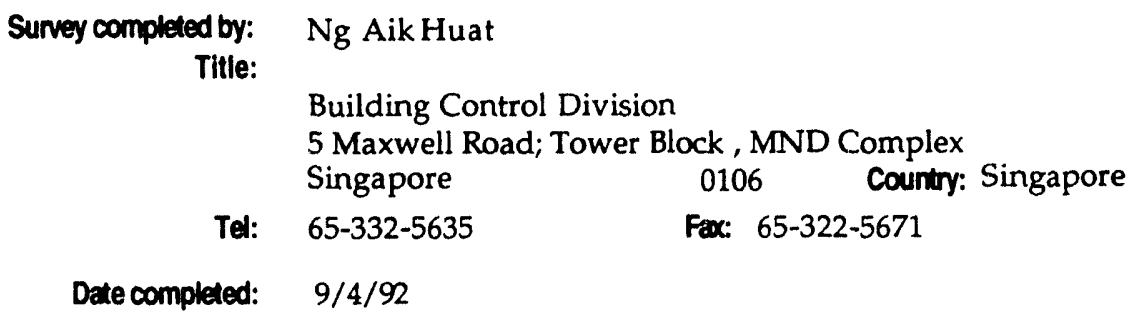




\section{GENERAL OVERVIEW OF BULLONG ENERGY STANDARDS}

1. General bulling stendards exist at the following governmental levels:

National

Local

2. Proposed or existing ENERGY standards cover the following bullding sectors: Non-Residential Only

3. Status of Non-Residential Bulling Energy Standards at the:

a National level: Voluntary

b. Regional level Voluntary

c. Local levet: - None

4. Single energy standard selected for further description:

Title, Organization: Department of Finance

Year: ? Geographic Coverage: Nation Abbreviated Title: BES-DF

\section{DESCRIPTION OF SPECIFEO ENERGY STANDARDS - BES-DF}

5. The standard defined in Question 4 applies to the following kinds of buildings:

a. Building types:

O- Offices

G-Government Facilities

D - Hospitals

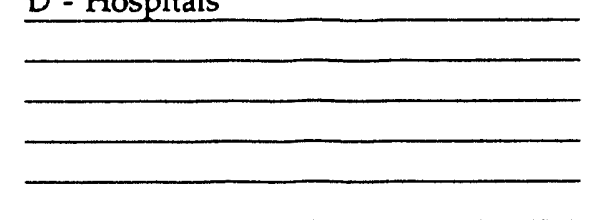

b. Building vintage:

New buildings

c. Other characteristics:

E - Amount of energy

6. Basic approach of the standard: Performance-based

7. The following subjects are included in the energy standard:

a. Whole buiding energy provisions:

E- Energy amount target

\section{c. Lighting provisions:}

?

e. Other provisions:

-None

\section{b. Building envelope provisions:}

?

d. Mechanical provisions:

?

$\underline{?}$ 


\section{STADDARDS DEVELOPUENT PAOCESS - BES-DF}

8. Organbations involved in developing the standerd:

Academic institution: University of Pretoria

9. Dectioion Process: Mandate

Comment:

10. Information used in doveloping the standerd:

a. PHYSICAL CHARACTERISTICS of existing buildings

Estimated using professional judgment

\section{c. WEATHER data}

Already available prior to standard

11. Standards from a different country used as source matertal:

- None

12. COMPUTER programs used:

a. In developing the standard: $\quad$ QUICK

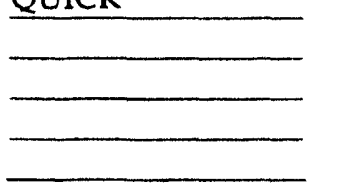

b. For complying with the standard: Yes

\section{d. Other information}

- Nione

Estimated using professional judgment

Computer simulations used for estimates

13. Standard is set at a level: Equal to current practice

14. Considerations intuencing the inclusion or exclusion of messures in the standard:

E - Cost effectiveness

Similarity/difference to local design

Comfort

15a. Standard scheduled for regular review and revision?

No

b. Does revision include procectures to MONTOR and EVALUATE earlier versions of the standand?
Comments:

? 
16. Entities involved in MPLEMENTWG energy standerds:

Existing agency: Department of Works

II an existing agency was made responstble for implementation, its former focus was on buldings, energy, or another aree: Buildings

17. TRANING \& EDUCATION provided for archinects, engineers and other protessionats:

- None

18. Compliance mechenisms used at difterent stages in construction process:

a. PRIOR to construction:

No mechanism

Percent designs chected: 5

Comment:

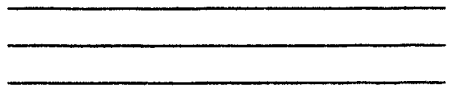

b. DURING construction:

No mechanism

Percent sites checked: 0

Comment:

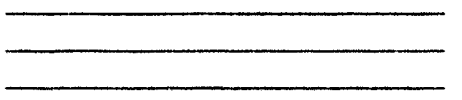

C. AFTER construction:

No mechanism

Percent buildings checked: 0 Comment:

$\longrightarrow$

\section{d. Other compliance procedures}

e. Effectiveness of combined compliance mechanisms (scale of 15): 1.5

f. Explanation for effectiveness in part e: Energy conservation not perceived as important: pollution (some) not perceived as important; coal produced; energy is cheap

19. Types of assessments or audits of energy standards' impact:

a. ENERGY SAVINGS POTENTIAL based on prototypical (not actual) buildings:

Completed: National Energy Council

b. MEASUREMENTS OF ENERGY SAVINGS in actual buildings complying with standard:

Completed: National Energy Council

In progress

c. COST EFFECTIVENESS besed on engineering economic CALCULATIONS:

In progress: National Energy Council

d. COST EFFECTIVENESS based on ACTUAL COSTS:

In progress: National Energy Council

e. Other Assessments: Planned: National Energy Council 


\section{FURTHER WFOAMATION ON EVERGY CONSERVATION - SOuth Africa}

\section{Efficiency reating tacllities and procedures extablished:}

Insulation

Thermal properties of materials

\section{Other programs or policies deviloped to increese energy efficlency in buildings:}

Audit manual made available (1987)

Time of day pricing introduced (1991)

but withdrawn
Comment: Audis manual free through Department of Public Works; high demand but few audits completed. Tariff introduced by Eskom on trial basis: withdrawn due to local authority electricity donartmonts

\section{Additional sources of information about energy efficiency for bullings in: South Africa}

1. Lewis, Basson, and Snow. "Efficient utilisation of electricity." NEC/Eskom Seminar on Electricity Strategy, April 1990.

2. Basson, "Energy Conservation R\&D, Progress Report from South Africa," Building Research and Practice Nox/Dec 1982

3. Matthysen, "Energy Consumption in Large Buildings, a South Africa survey," South Africa Refrigeration and Air Conditioning Nov. 1986.

22. Contact for written copy of energy standard spectied in Question 4:

Name:

Address:

Country:

Tel:

Fax:

Types of supporting information avalable:

Other energy standards for non-esidential buildings:

Survey completed by: J.A. Basson

Title: Director, Electricity and Energy Efficiency

Energy Branch, Department of Mineral and Energy

Private Bag X03

Lynnwood Ridge, Pretoria $0040 \quad$ Country: South Africa

Tel: $2712348-9564 \quad$ Fax: $2712348-9676$

Date completed: $\quad 5 / 5 / 92$ 


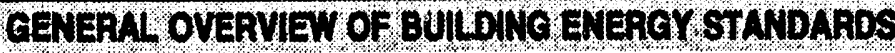

1. Generel bulling standerds exist at the following governmantal levels: National

2. Proposed or existing ENERGY standards cover the following building sectors: Both Residential and Non-Residential

3. Status of Non-Residential Bullding Energy Standards at the:

a Netional level: Mandatory b. Regional lovel:

c. Local level:

$\longrightarrow$

4. Single energy standand selected for further description:

Tule, Organizutiont: Building Code. Ministry of Construction. Effective June 1. 1992

Year: 1992 Geographic Coverage: Nation Abbreviated Thtle: BC-1992

\section{BESCRIPION OF SPECIFEO ENERGY STANDARDS- BC-1992}

5. The standard defined in Question 4 applies bo the following linds of buildings:

a. Building types:

$\mathrm{O}$ - Offices

H - Hotels

G - Government Facilities

F - Restaurants

D - Hospitals

C - Commercial/retail stores

S - Single-family residential

M - Multi-family residential b. Building vintage:

New buildings

c. Other characteristics:

$\mathrm{P}$ - Physical size: offices/shopping centers $>3000$ sq. $\mathrm{m}$

6. Basic approach of the standard: Both prescriptive and performance

7. The following subjects are included in the energy standard:

a Whole buiding energy provisions:

E- Energy amount target (residential \& office)

\section{c. Lighting provisions:}

Control requirements

Power density

Illumination requirements

\section{e. Other provisions:}

Yes: thermostat settings, and Ondol heating system (traditional floor panel heating system)

b. Bulating envelope provisions:

Roof

Wall system

Fenestration system

Infiltration

d. Mecharical provisions:

Load Calculations for equipment sizing Controls

Equipment efficiency 


\section{STANDARDS DEVELOPMENT PROCESS - BC-1992}

\section{Organteations involved in developing the standart:}

Government agency: Ministry of Construction Govemment agency: Ministry of Energy and Resources

Research group: Korea Institute of Energy Research

\section{Decision Process: Cansensus Comment:}

\section{Whometion used in doveloping the standert:}

\section{a. PHYSICAL CHARACTERISTICS of existing buildings}

Estimated using professional judgment Gathered through audits and surveys Already available prior to standard

\section{WEATHER data}

Gathered through measurements Already available prior to standard

11. Standards from a different country used as source matertal:

USA: BEPS

USA: ASHRAE 90.1

Japan: PAL, Building Code, and oth. stds.

\section{b. ENERGY USE of existing buldings:}

Estimated using professional judgment Computer simulations used for estimates Gathered through audits and surveys Already available prior to standard

\section{d. Other information}

=None
12. COMPUTER programs used:

a. In developing the standerd:

DOE-2

Trakload

TRNSYS

KIZRB1

b. For complying with the standand: Yes

13. Standard is set at a level: Above current practice

14. Considerations inturencing the inctusion or exclusion of measures in the standard:

E - Cost effectiveness

A - Availability of energy efficient products

$\mathrm{S}$ - Similarity/difference to local design

C - Comfort

Comments:

Some of energy efficient products are imported from. foreign countries.

15a. Standard scheduled for regular review and revision?

Yes: review in research institute $\Rightarrow 2$ governmental agency $\Rightarrow$ revision

b. Does revision include procectures to MONITOR and EVALUATE earlier versions of the standard?

Yes 


\section{SOUTH KOREA}

\section{ILPLEMENTATION AND COMPLANCE - BC-1992}

\section{Entities involved in MPLEMENTnG energy standinds:}

Existing agency: Ministry of Construction and Ministry of Domestic Affairs

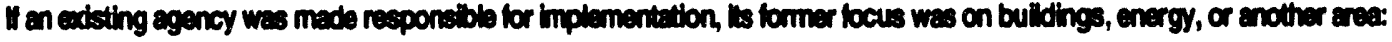

Buildings

\section{TRANHG \& EDUCATION provided for architects, engineers and other profecsionals:}

Written guidelines to assist with compliance procedure

Example calculations

Compliance forms

Seminars, workshops, or conferences

18. Complence mectentisms used at difterent stages in construction process:

a. PRiOR to construction:

Certification/approval

Percent designs chected: 50

comment:

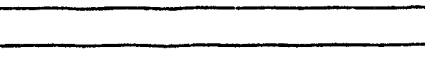

\section{b. DURING construction:}

Certification/approval Other policy mechanism

Porcent stres chected: 50 Comment
C. AFTER construction:

Certification/approval

Penalty

Percent bullotings checkect. 100 comment:

d. Other compliance procedures Yes: we have to receive the inspections for fire protection, utility hookups, etc.

e. Effectiveress of combined compliance mechanisms (scale of 1-5): 3

1. Explanation for effectiveness in part e: We don't have perfect one.

19. Types of assessments or audits of energy standards' impact:

a. ENERGY SAVINGS POTENTIAL based on prototypical (not actual) buildings:

Planned

b. MEASUREMENTS OF ENERGY SAVWiGS in actual bulldings complying with standard: Planned

c. COST EFFCTIVENESS based on engineering economic CALCULATIONS:

Planned

d. COST EFFECTIVENESS based on ACTUAL COSTS:

Planned

e. Other Assessments: Planned 


\section{FURTHER WFOAMATION ON ENERGY CONSERVATION - SOUth KOREa}

20. Efficiency besting tecillibes and procedures established:

Motors

Insulation

Air conditioners/chillers/other appliances

Ballasts

Fixtures

Thermal properties of materials

\section{Other progrems or pollcies developed to increece energy eflicioncy in buldings:}

Government energy policy

Utility initiatives

Information programs

Audits (free or subsidized)
Comment: Electricity peak load reduction:Ministry of Energy and Resources;

Additiond sources of information about energy efficiency for buildings in: South Korea

1. Energy Research and Development, Korea Insitute of Energy Researci.

2. Energy Management, Korea Energy Management Corporation

3. Energy Economy (newspaper)

\section{Contact for witten copy of energy standard specified in Question 4:}

Name Sang Dong Park

Address: Director, Building Energy Research Departmen

Korea Institute of Energy Research

P.O. Box 5, Daedeok Science Town

Daejeon 305-343

Country: Korea
Tel:
82428603200
Fax: $\quad 82428616224$

Types of supporting information avalable:

- None

Other energy standands for non-residentlal bulldings:

Rational Energy Utilization Law, Ministry of Energy and Resources

Survey completed by: Sang Dong Park

Title: Director, Building Energy Research Department

Korea Institute of Energy Research

P.O. Box 5, Daedeok Science Town

Daejeon 305-343

Country: Korea

Tel: $82428603200 \quad$ Fax: 82428616224

Date completed: $\quad 11 / 10 / 92$ 
1. Cenerd bulling stendards exist at the following governmental lovels:

National

2. Proposed or existing ENERGY standerds cover the following building sectors: Both Residential and Non-Residential

3. Status of Non-Residential Buiding Energy Standards at the:
a National lovet.
Mandatory
b. Regionel bevel:

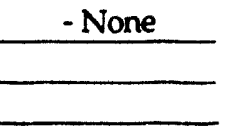
C. Local levet:
- None

4. Single energy standard selected for further description:

Thile, Organization: Nybyggnadsregler, BES 1988: 18. Boverket, 1989-01-01

Year: 1989 Geographic Coverage: Nation Abbreviated Title: BFS 1988: 18

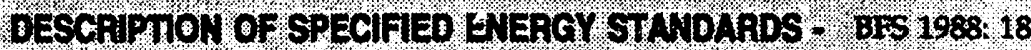

5. The standard defined in Question 4 applies to the following linds of buildings:

a. Building types:

A - All Buildings

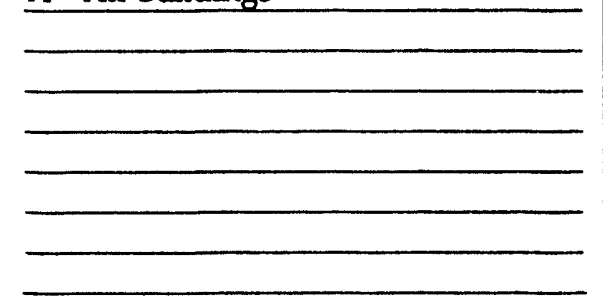

b. Buiding vintage:

New buildings

c. Other characteristics:

Other: all permanently used buildings

6. Basic approach of the standard: Performance-based

7. The following subjects are included in the energy standerd:

a Whole bulding energy provisions:

Other: reference building

\section{c. Lighting provisions:}

Illumination requirements: daylighting

Other: daylighting

\section{e. Other provisions:}

Heat exchanger for ventilation b. Bulding envelope provisions:

Roof

Wall system

Fenestration system

Infiltration

\section{d. Mechenisid provisions:}

Ventilation 


\section{4}

\section{Organtations incived in developing the standart:}

Government agency: Boverket

9. Decision Process: Mandate

Comment: Boverket

10. If

a. PHYSCAL CHARACTERISTCS of existing buildings

c. WEATHER deta

Already available prior to standard

11. Stendands from a difterent country used as source material:

- None

\section{b. ENERGY USE of existing buildings:}

Estimated using professional judgment Computer simulations used for estimates

\section{d. Other information}

-None

12. COMPUTER prugrams used:

a. In developing the standart: ENORM

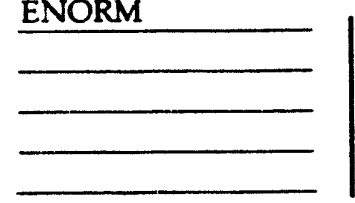

b. For complying with the standard: Yes

13. Standard is set at a level: Above current practice

\section{Considerations influencing the inctusion or exchsion of measures in the standant:}

$E$ - Cost effectiveness

Comfort

Comments:

15a Standard schectuled for regultar review and revision?

Yes

b. Does revision inchude procedures to MONTOR and EVALUATE earlier versions of the standand?

Yes 


\section{SWEDEN}

\section{ILPLELENTATON AND COLIPLANCE - BPS 1988: 18}

16. Entities involved in MPLEMENTIMG energy standards:

Existing agency: Boverket

If an existing agency was made responsible for inplementation, its former focus was on buldings, energy, or another area:

Buildings

17. TRAWUNG \& EDUCATION provided for architects, engineers and other professionals:

Written guidelines to assist with compliance procedure

Example calculations

Seminars, workshops, or conferences

Information or resource center

18. Compliance mechanisms used at different stages in construction process:

\section{a. Prior to construction:}

Certification/approval

Percent designs checked: 100

Comment

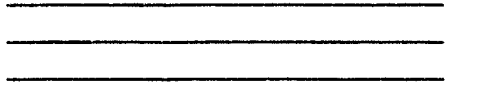

b. DURivi construction:

Certification/approval

Percent sites checked: $1-100$

Comment:

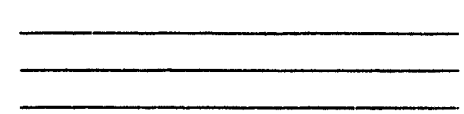

C. AFTER construction:

Certification/approval

Percent buildings checked: 100

comment

d. Other compliance procedures - None

e. Effectiveness of combined compliance mechenisms (scale of 1-5): 5

f. Explanation for effectiveness in part e: Why not?

19. Types of assessments or audits of energy standands' impact:

a. ENERGY SAVINGS POTENTIAL besed on prototypizal (not actual) buildings:

b. MEASUREMENTS OF ENERGY SAVINGS in actual buildings complying with standard:

c. COST EFFECTIVENESS based on engineering economic CALCULATIONS:

d. COST EFFECTIVENESS based On ACTUAL COSTS:

e. Other Assessments: 


\section{FURTHER WFOAMATION ON ENERGY CONSERVATION - SwEden}

\section{Efficiency lesting facilities and procedures established:}

Insulation

Air conditioners/chillers/other appliances

Thermal properties of materials

21. Other programs or policies developed to increase energy efficiency in buildings:

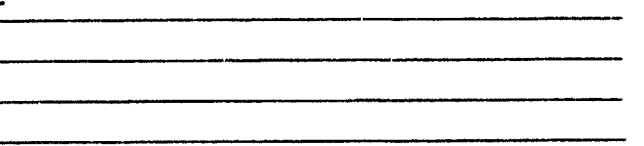

Comment:

Additional sources of information about energy efficiency for buildings in: Sweden

1. Nybggnads Regler, BES 1988: 18, ISBN 91-38-09758-3

2.

3.

22. Contact for written copy of energy standard specified in Question 4:

Name Stephan Norrman

Address: Boverket

Box 534 S37123 Karlskrona

Country: Sweden

Tel: $\quad 4645553215$

Fax: $\quad 4645553221$

Types of supporting information available:

Byggtjanst: S171 88 Solna, Sweden; tel: 468734 5100; fax: 4687345098

Other energy standards for non-residential buildings:

- None

Survey completed by: Stephan Norrman

Title: Boverket

National Board of Housing, Building and Physical

P.O. Box 534

S-37-123 Karlskrona Country: Sweden

Tel: $\quad+46-455-53-215 \quad$ Fax $\quad+46-455-53-221$

Date completed: $\quad 6 / 25 / 92$ 


\section{GENERAL OVERYIEY OF BUILIIG ENERGY STANDARDS}

1. General building standards exist at the following governmental lovels:

National

2. Proposed or existing ENERGY standards cover the following building sectors: Both Residential and Non-Residential

3. Status of Non-Residential Building Energy Standards at the:
a National level:
b. Regional level
c. Local beve: Mandatory

Mandatory

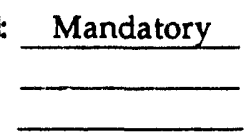

4. Single energy standard selected for further description:

Title, Organization: Energie im Hochbau. Schweizerischer Ingenieur und Architekrenverein (SIA)

Year: 1988 Geographic Coverage: Nation Abbreviated Title: EH-SIA, 1988

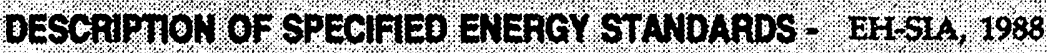

5. The standard defined in Question 4 applies to the following kinds of buildings:

\section{a. Building types:}

A - All Buildings

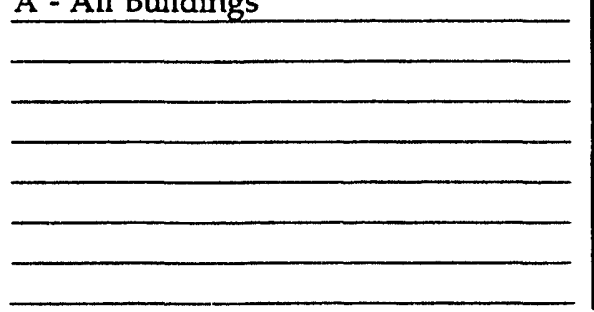

b. Builing vintage:

Both new and existing

C. Other characteristics:

P - Physical size

E - Amount of energy

F - Type of fuel: oil, gas, electricity

6. Basic approach of the standard: Both prescriptive and performance

7. The following subjects are included in the energy standard:

a. Whole buiding energy provisions:

E- Energy amount target

a. Lighting provisions:

- None

e. Other provisions:

-None b. Buiding envelope provisions:

Roof

Wall system

Fenestration system

Infiltration

\section{d. Mectanical provisions:}

Load Calculations for equipment sizing Equipment efficiency 
STANDARDS DEVELOPYENT PROCESS - EH-S1A, 1988

8. Organtations involved in developing the standerd:

Government agency: Bundesant energiwirishaft

Academic institution: SIA

9. Decision Process: Consensus Comment:

10. Intormation used in developing the standard:

a. PHYSICAL CHARACTERISTICS of existing buildings

Already available prior to standard

\section{WEATHER data}

Already available prior to standard

11. Stendands from a different country used as source material:

Germany: DIN

France: AFNOR

\section{b. ENERGY USE of exdsting buildings:}

Estimated using professional judgment

\section{d. Other information}

-None

12. COMPUTER programs used:

a. In developing the standard:

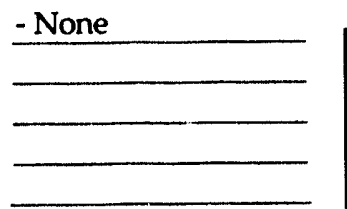

b. For complying with the standand: ?

13. Standard is set at a lovel: Lower than current practice

14. Considerations inthencing the inclusion or exclusion of meesures in the standard:

E - Cost effectiveness

C-Comfort

Comments:

15a Standard schectuled for regular review and revision?

Yes

b. Does revision include procectures to MONTOR and EVALUATE earlier versions of the standard?

Yes 


\section{IMPLEMENTATION AND COMPLIANCE - EH-SLA, 1988}

16. Entities imolved in WMPLEMENTING energy standards:

If an existing agency was made responsible for implementation, its former focus was on buildings, energy, or another area:

$?$

17. TRANING \& EDUCATION provided for architects, engineers and other professionals:

Example calculations

Seminars, workshops, or conferences

Information or resource center

18. Compliance mechanisms used at different stages in construction process:

a. PRIOR to construction:

Certification/approval

Percent designs checked: 100

Comment:

b. DURING construction:

Percent siles checked:

Comment:

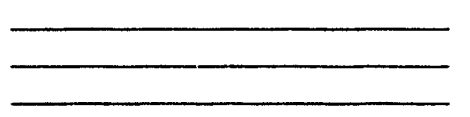

C. AFTER construction:

Percent buileings checked:

Comment:

\section{d. Other compliance procedures}

e. Effectiveness of combined compliance mechanisms (scale of 1-5):

1. Explanation for effectiveness in part e:

19. Types of assessments or audits of energy standards' impact:

a. ENERGY SAVINGS POTENTIAL based on prototypical (not actual) buildings:

In progress

b. MEASUREMENTS OF ENERGY SAVWGS in actual buildings complying with standard: In progress

c. COST EFFECTIVENESS based on engineering economic CALCULATIONS:

In progress

d. COST EFFECTIVENESS based on ACTUAL COSTS:

In progress

e. Other Assessments: 
20. Efficiency lesting tacilities and procedures established:

Insulation

Air conditioners/chillers/other appliances

Thermal properties of materials

21. Other progrems or policies doveloped to increase energy efficiency in buildings:

Building energy standards

$\longrightarrow$

Comment: SIA 380/4 Elektrische Energie im Hachbau

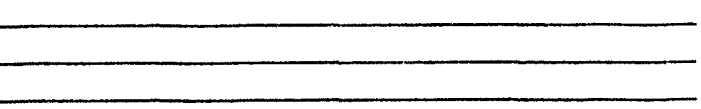

Additional sources of information about energy efficiency for buildings in: Switzerland

1.

2.

3.

22. Contact for written copy of energy standard specified in Question 4:

Name

Address:

Country:

Tel:

Fax:

Types of supporting information available:

Other energy standards for non-residential buildings:

Title: Dipl. Arch

Schweizerischer Ingenieur und Architekrenverein

Postfach CH-8039

Zürich

Country: Switzerland

Tel: $\quad 4113831515$

Fax: 4112016335

Date completed: $\quad 7 / 14 / 92$ 


\section{GENERAL OVERVIEW OF BUILDING ENERGY STANDARDS}

1. General building standards exist at the following governmental levels:

National

2. Proposed or exdsting ENERGY standerds cover the following building sectors: Non-Residential Only

3. Status of Non-Residential Building Energy Standands at the:
a National level:
Proposed
b. Regional level:
Proposed
c. Local bevel: Proposed

4. Single energy standard selected for further description:

Title, Organization: "Ifuidelines and Requirements for Energy Conservation in New Buildings, "National Energy Office, Office of the Prime Minister, and the Ministry of Science, Technology, and Energy

Year: 1987 Geographic Coverage: Nation Abbreviated Title: ECNB, 1987

DESCAIPTION OF SPECIFIED ENERGY STANDARDS - ECNB, 1987

5. The standard defined in Question 4 applies to the following kinds of buildings:

\section{a. Building types:}

$\mathrm{O}$ - Offices

H - Hotels

G-Government Facilities

F-Restaurants

D - Hospitals

C - Commercial/retail stores b. Building vintage:

Both new and existing

c. Other characteristics:

E - Amount of energy: 1000 kilowatts

6. Basic approach of the standard: Prescriptive

7. The following subjects are included in the energy standard:

a. Whole buiding energy provisions:

- None

c. Lighting provisions:

Control requirements

Power density

e. Other provisions:

-None b. Buiding envelope provisions:

Roof

Wall system

Fenestration system

Infiltration

\section{d. Mechanical provisions:}

Load Calculations for equipment sizing

Ventilation

Equipment efficiency 


\section{STANDARDS DEVELOPMENT PROCESS - ECNB, 1987}

8. Organizations involved in developing the standard:

Government agency: Dept. of Energy Affairs, Ministry of Science, Technology, and Energy

Government : National Energy Policy Office, Office of Prime Minister

Academic : Division of Energy Technology, Asian Institute of Technology

9. Decision Process: Mandate

Comment:

10. Intormation used in developing the standard:

a. PHYSICAL CHARACTERISTICS of existing buildings

Already available prior to standard

\section{c. WEATHER data}

Already available prior to standard

11. Standards from a different country used as source material:

Singapore

USA: ASHRAE 90 A,B,C

\section{b. ENERGY USE of existing buindings:}

Already available prior to standard

\section{d. Other information}

The standards have been developed based on information compiled for central region. More information is being comoiled to strengthen the

12. COMPUTER programs used:

a. In developing the standard: DOE-2

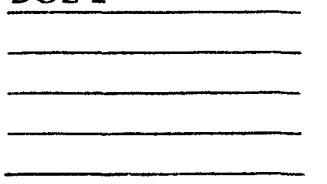

b. For complying with the standard: Yes

13. Standard is set at a level: Above current practice

14. Considerations influencing the inclusion or exclusion of measures in the standand:

E - Cost effectiveness

Availability of energy efficient products

Similarity/difference to local design

Comfort

comments:

15a Standard scheculed for regular review and revision?

Yes: It is believed that a review procedure will be developed.

b. Does revision include procectures to MONITOR and EVALUATE eartier versions of the standard? 


\section{THAILAND}

IMPLEMENTATON AND COMPLIANCE - ECNB, 1987

16. Entities imvolved in IMPLEMENTNG energy standards:

Existing agency: Dept. of Energy Affairs

If an existing agency was made responsible for implementation, is former focus was on buldings, energy, or another area:

Energy

17. TRANING \& EDUCATION provided for architects, engineers and other protessionals:

Written guidelines to assist with compliance procedure

Example calculations

18. Compiance mechanisms used al different stages in constuction process:

a. PRIOR to construction:

Penalty

Percent designs checked: 100

Commert:

b. DURWiG construction:

Penalty

Percent sites checked:

Commert:

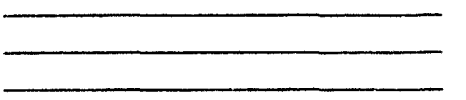

c. AFTER construction:

Penalty

Percent buildings checked: 100

Comment:

\section{d. Other compliance procedures}

e. Eflectiveness of combined complience mechanisms (scale of 1-5):

f. Explanation for effectiveness in part e: =

19. Types of assessments or audits of energy standards' impact:

a. ENERGY SAVINGS POTENTLAL based on prototypical (not actual) buildings:

In progress

b. MEASUREMENTS OF ENERGY SAVWGS in actual buildings complying with standard:

Planned

c. COST EFFECTIVENESS based on engineering economic CALCULATIONS:

Planned

d. COST EFFECTIVENESS based on ACTUAL COSTS:

None conducted

e. Other Assessments: None conducted 


\section{FURTHER WFORMATION ON ENERGY CONSERVATION - Thailand}

20. Efficiency lesting tacillities and procedures established:

Air conditioners/chillers/other appliances

\section{Ballasts}

\section{Other programs or policies developed to increase energy efficiency in buildings:}

Utility initiatives Government energy policy

\section{Additional sources of intormation about energy efficiency for buildings in: Thailand}

1. Publications in joumals of: Engineering Institute of Thailand

2. Publications in jolumals of: Siam's Architectural Society

3.

\section{Contact for witten copy of energy standand specitied in Question 4:}

Name

Address: Division of Energy Economics

Department of Energy Affairs

Ministry of Science, Technology, and Energy

Rama I Road Bangkol.

Countin: Thailand

Tel:

Fax:

Types of supporting information avallable:

Handbook on Energy Conservation for Buildings

Other energy standards for non-residential buildings:

- None

Survey completed by: Surapong Chirarattananon

Title: Energy Technology Division

Asian Institute of Technology

GPO Box 2754

Bangkok

10501

Country: Thailand

Tel: $\quad 662-529-0100$

Fax: $662-516-2126$

Date completed: $\quad 4 / 15 / 92$ 


\section{GENERAL OVERVIEW OF BUILDING ENERGY STANDARDS}

1. General bullding standards exist at the following governmental levels:

National

2. Proposed or existing ENERGY standards cover the following bulling sectors: Both Residential and Non-Residential

3. Status of Non-Residential Buliding Energy Standards at the:

a. Netional lovel:

$$
\text { Proposed }
$$

b. Regional level:

Proposed

c. Local buri:

- None

4. Single energy standard selected for further description:

Thle, Organization: Building Thermophysics (draft). The Research Institute for Building Physics (NIISE)

Year: 1991

$$
\text { Geographic Coverage: Nation }
$$

Abbreviated Title: BT-NIISF, 1991

\section{DESCRIPTION OF SPECIFIED ENERGY STANDARDS - BT-NISF, 1991}

5. The standand defined in Question 4 applies to the following kinds of buildings:

a. Building types:

A - All Buildings b. Builing vintage:

Both new and existing

C. Other characteristics:

E - Amount of energy: minimization during design process

6. Basic approach of the standard: Performance-based

7. The following subjects are included in the energy standand:

a Whole buiding energy provisions:

E- Energy amount target

\section{c. Lighting provisions:}

- None

e. Other provisions:

-None b. Buiding envelope provisions:

Roof

Wall system

Fenestration system

Infiltration

Other: main floor above and helow grade

\section{d. Mecharical provisions:}

- None 
STANDARDS DEVELOPUENT PROCESS - BT-NIISE, 1991

8. Organteations involved in developing the standerd:

Research group: The Research Institute for Building Physics

Research group: The Research and Design Institute for Industrial Buildings

Research group: The Research and Design Institute for Residential Buildings

Research group: The Research and Design Institute for Rural Buildings

9. Decision Process: Consensus comment:

10. Information used in doveloping the standard:

a. PHYSICAL CHARACTERISTCS of existing bulldings

Already available prior to standard

\section{c. WEATHER data}

Already available prior to standard

11. Stendands from a different country used as source material:

ISO-9164

Germany: DNN 4108

Sweden: SBN 1980

America: California Energy Code

\section{b. ENERGY USE of existing buildings:}

Computer simulations used for estimates

Gathered through audits and surveys

\section{d. Other information}

-None

12. COMPUTER programs used:

a. In developing the standard:

HEAT

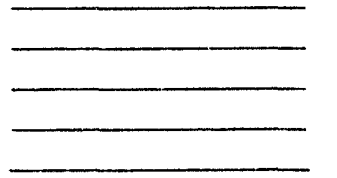

b. For complying with the standard: Yes

13. Standard is set at a level: Above current practice

\section{Considerations influencing the inctusion or exclusion of measures in the standend:}

E - Cost effectiveness

Availability of energy efficient products

Comfort
Comments:

\section{5a Standard scheduled for regular review and revision?}

Yes: every five years

b. Does revision include procectures to MONTOR and EVALUATE earlier versions of the standard?

$\mathrm{No}$ 
3 U.S.S.R.

IMPLENENTATION AND COMPLLANCE - BTANIISE, 1991

16. Entities imolved in IMPLEMENTWG energy standerds:

Existing agency: Research Institute for Building Physics

W en wisting agency wes made responsibib for implementation, lis former focus was on bulidings, energy, or another area

Buildings and energy

17. TRANING \&DUCATION provided for anchilects, engineers and other protessionals:

- None

18. Compience mechanisms used a diflerent stages in construction process:

a. Prior b construction:

-

Percent designs cheched:

Comment:

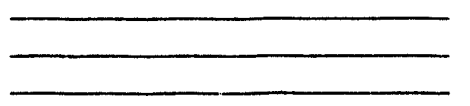

b. DURing construction:

-

-

Percent siles checked:

Comment:

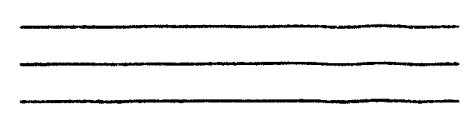

C. AFTER construction:

Certification/approval

Percent buildings checked:

comment:

\section{d. Other compliance procedures}

e. Eltectiveness of combined compliance mechanisms (scale of 1-5): 3

f. Explanation for effectiveness in pert e:

19. Types of assessments or aucits of energy standerds' impact:

a. ENERGY SAVINGS POTENTIAL based on prototypical (not actual) buildings:

Planned

b. MEASUREMENTS OF ENERGY SAVIVGS in actual buildings complying with standard:

In progress

c. COST EFFECTIVENESS besed on engineering economic CALCULATIONS:

In progress

d. COST EFFECTIVENESS based ON ACTUAL COSTS:

None conducted

e. Other Assessments: 
FURTIER WFORMATION ON ENERGY CONSERVATION - U.S.S.R.

20. Efficiency testing facillies and procedures established:

Insulation

Thermal properties of materials

Other: Thermal properties of envelope; air-tightness; energy consumption

21. Other programs or policies developed to increase energy efficiency in bulldings:

Government energy policy

$\longrightarrow$

Commert: Energy policy of Russian Federation in new economic conditions, Russian Govermment

\section{Additional sources of information about energy efficiency for buildings in: U.S.S.R.}

1. Methodology and Principles Involved in the Setting of Codes on Building Heat Engineering in the US.S.R." Energy and Buildings (1990) 14: 401-409

2. "Concepts of the Development of Building Physics in the U.S.S.R" Energy and Buildings (1992) 13: 25-33.

3. Yu.Matrosov. "Trends of Development of Energy Consumption in Buildings and Energy Efficiency Projects Being Undertaken in the Soviet Union" 15th Annual International Scientific Forum, "Making

22. Contact for written copy of energy standard specitied in Question 4:

Name

Address:

Country:

Tel:

Fax:

Types of supporting intormation available:

Other energy standards for norresidential buildings:

Survey completed by: Dr. Yu. A. Matrosov

Title: Head of Laboratory

Research Institute for Building Physics (NIISF)

21, Locomotivnij proezd

127238 Moscow

Country: USSR

Tel: $\quad 7095482-3710 \quad$ Fax: $7095482-4060$

Date completed: $\quad 5 / 15 / 92$ 
GENERAL OVERVIEN OF BUILDING ENERGY STANDARDS

1. General builing standards exist at the following governmental levels:

National

Regional

Local

2. Proposed or existing ENERGY standands cover the following building sectors: Both Residential and Non-Residential

3. Status of Non-Residential Building Energy Standards at the:

a National levet:

\begin{tabular}{c} 
Mandatory \\
\hline Voluntary
\end{tabular}

b. Regional kevel:

\begin{tabular}{c} 
Mandatory \\
\hline Voluntary \\
\hline
\end{tabular}

c. Local level: Mandatory Voluntary

4. Single energy standard selected for further description:

Ttle, Organization: "Energy Efficient Design of New Buildings Except New Low-Rise Residential Buildings," ASHRAE/IES, 1989.

Year: 1989

Geographic Coverage: Nation

Abbreviated Title: ASHRAE $90.1-89$

\section{DESCRIPTION OF SPECIFIED ENERGY STANDARDS - ASHRAE $901-89$}

5. The standard defined in Question 4 applies to the following kinds of bulldings:

a. Building types:

O - Offices

H - Hotels

F - Restaurants

D - Hospitals

$\mathrm{R}$ - Religion-related

C-Commercial/retail stores

E - Educational facilities (schools)

I - Industrial Bldgs (non-process areas) b. Building vintage:

New buildings

c. Other characteristics:

O - Other: buildings designed for human occupancy (not storage)

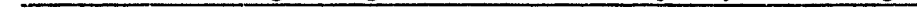

6. Basic approach of the standard: Both prescriptive and performance

7. The following subjects are included in the energy standard:

a. Whole buinding energy provisions:

C- Energy cost target

\section{Lighting provisions:}

Control requirements

Power density

\section{e. Other provisions:}

Yes: service water heating b. Buiding envelope provisions:

Wall system

Fenestration system

\section{d. Mecharical provisions:}

Load Calculations for equipment sizing

Controls

Ventilation

Equipment efficiency 


\section{Organizations involved in developing the standard:}

Government agency: Department of Energy, Office of Building Technology

Research group: American Society of Heating, Refrigeration, and Air-Condintioning Engineers

Industry group: Gas Appliance Manufacterers Assn (GAMA); Air-Conditioning and Refrigeration Inst. (ARI) Industry group: North American Insulation Manuf. Assn. (NAIMA); Portland Cement Assn. (PCA) Industry group: National Concrete and Masonry Assn. (NCMA); Primary Glass Manuf. Council (PGMC);

\section{Decision Process: Consensus}

comment:

\section{Information used in developing the standard:}

a. PHYSICAL CHARACTERISTICS of existing buildings

Estimated using professional judgment

\section{c. WEATHER data}

Already available prior to standard

11. Standards from a different country used as source material: - None

\section{b. ENERGY USE of existing buildings:}

Computer simulations used for estimates

\section{d. Other information}

-None

12. COMPUTER programs used:

\section{a. In developing the standard: DOE-2}

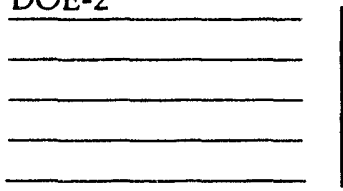

b. For complying with the standard: Yes: Software

13. Standard is set at a level: Above current practice

14. Considerations influencing the inclusion or exchusion of measures in the standand:

A - Availability of energy efficient products C - Comfort

Comments:

\section{5a Standard scheduled for regular review and revision?}

Yes: Standards are reviewed on a five year cycle for revision or reaffirmation

\section{b. Does revision include procectures to MONTOR and EVALUATE earlier versions of the standard?}

No 
16. Entities involved in IMPLEMENTING energy standards:

Existing agency: Department of Energy

Other non-governmental agency: Building code officials (ICBO, CABO, SBCCI, BOCA)

If an existing agency wes made responsible for implementation, its former focus was on buildings, energy, or another area:

Energy

17. TRAINING \& EDUCATION provided for architects, engineers and other professionals:

Written guidelines to assist with compliance procedure

Example calculations

Seminars, workshops, or conferences

18. Compliance mechanisms used at different stages in construction process:

a. PRIOR to construction:

Certification/approval

Percent designs checked: ?

Comment: b. DURING construction:

Uncertain

Percent sites checked: ?

comment: c. AFTER construction:

Uncertain

Percent buildings checked: ? Comment:
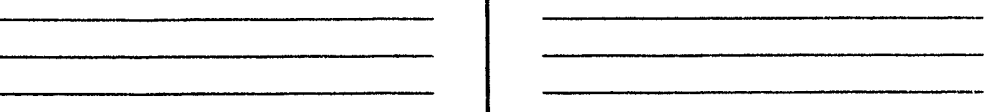

d. Other compliance procedures - None

e. Effectiveness of combined compliance mechanisms (scale of 1-5): 5

f. Explanation for effectiveness in part e: Most commercial buildings require the professional seal of a registered architect or engineer in order to be approved.

19. Types of assessments or aucits of energy standards' impact:

a. ENERGY SAVINGS POTENTIAL based on prototypical (not actual) buildings:

Completed: ASHRAE Journal and Transactions

b. MEASUREMENTS OF ENERGY SAVINGS in actual buildings complying with standard:

Completed: ASHRAE Journal and Transactions

c. COST EFFECTIVENESS based on engineering economic CALCULATIONS:

None conducted

d. COST EFFECTIVENESS based on ACTUAL COSTS:

None conducted

e. Other Assessments: None conducted 
20. Efficiency testing tacilities and procedures established:

\section{Motors}

Insulation

Air conditioners/chillers/other appliances

Thermal properties of materials

21. Other programs or policies doveloped to increase energy efficiency in buildings:

Utility initiatives

Government energy policy

Comment:

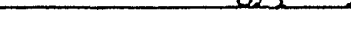

Additional sources of information about energy efficiency for buildings in: USA

1.

2.

3.

22. Contact for written copy of energy standard specified in Question 4:

Name:

Address: ASHRAE

1791 Tullie Circle, NE

Atlanta GA 30329

Country: USA

Tel: $\quad 404-636-8400$

Fax: $\quad 404-321-5478$

Types of supportiny information available:

Other energy standards for non-residential buildings:

Department of Energy Standards: Jean Boulin; 1000 Independence Ave.: Washington, D.C. 20585

Survey completeit:: Merle McBride

Title: Research Associate

Owens-Corning Fiberglass Corp.Bldg.; 72-1

2790 Columbus Road, Rt. 16

Granville, OH 43023-1200

Country: USA

Tel: $614-587-7083 \quad$ Fax: $614-587-7009$

Date completed: $\quad 11 / 4 / 92$ 

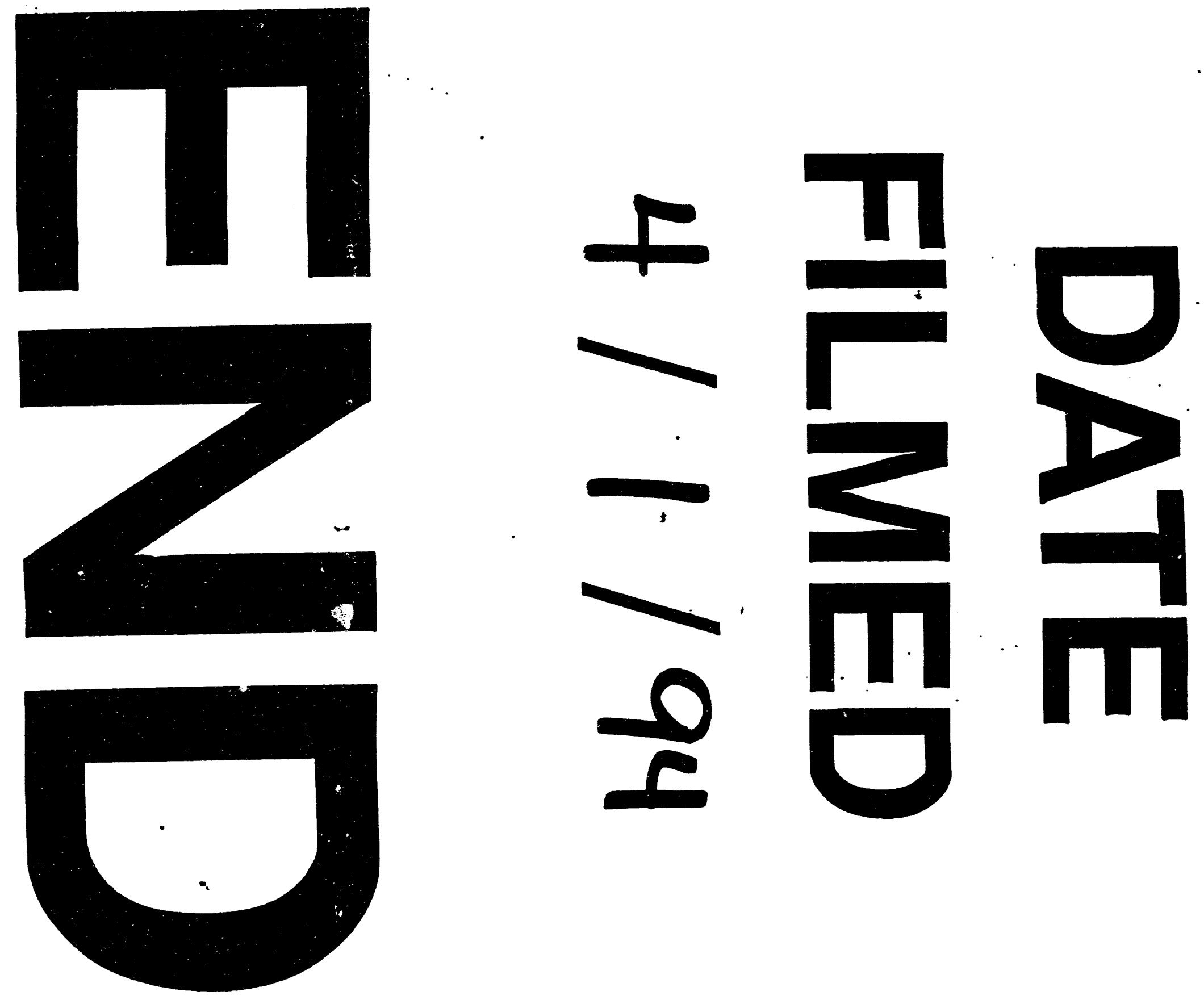
